\title{
ORIGINS OF FEDERAL COMMON LAW: PART ONE*
}

\section{STEWART JAY†}

"Federal courts, unlike state courts, are not general common-law courts and do not possess a general power to develop and apply their own rules of decision." Appearing in Milwaukee v. Illinois, this is about as axiomatic a statement concerning federal jurisdiction as can be found. Although it would be difficult to deny that the scope of modern federal jurisdiction is enormous, there nevertheless remains a sense that a radical difference exists between the nature of the state and federal judiciaries. The demarcation is usually expressed by noting that federal courts, in contrast to their state counterparts, are of "limited jurisdiction." This is a venerable maxim, which can be found in American cases from as early as the eighteenth century. Chief Justice Ellsworth, in a 1799 opinion, used the idea of "limited jurisdiction" to mean that a federal court "has cognisance, not of cases generally, but only of a few specially circumstanced, amounting to a small proportion of the cases which an unlimited jurisdiction would embrace."3 And, in Milwaukee v. Illinois itself, the Court reached back to the 1812 decision of United States $v$. Hudson ${ }^{4}$ as authority for its description of what is surely the

- Copyright 1985 by Stewart Jay. All rights reserved.

* Part Two of this essay appears at 133 U. PA. L. Rev. 1231 (1985).

$\dagger$ Associate Professor of Law, University of Washington. A.B. 1973, Georgetown University; J.D. 1976, Harvard University.

Thanks to Charles Corker, Tom Krattenmaker, Maeva Marcus, Gerry Spann, Ted Stein, and Mark Tushnet who read and offered valuable suggestions for earlier versions of this essay.

A special note of gratitude is due to Maeva Marcus, Director of the Documentary History Project, Supreme Court of the United States. In addition to answering numerous questions, she provided access to the Project's files of early grand jury charges, which are referred to extensively here. The charges will eventually be published in volume three of the Project's series, The Documentary-History of THE SuPREME CouRT 1789-1800.

Thanks also to Kathryn Preyer, Jim Buchanan, and Charles F. Hobson for a number of very helpful discussions. Professor Preyer has recently completed an interesting manuscript on the common-law criminal jurisdiction of the early federal courts; although the author of this essay has read the draft, it was received too late to permit comment.

The research on this essay was assisted by grants from the University of Washington Law Foundation.

This work is dedicated to Ted L. Stein (1952-1985).

1 Milwaukee v. Illinois, 451 U.S. 304, 312 (1981).

2 See C. Wright, The Law of Federal Courts 22 (4th ed. 1983).

3 Turner v. Bank of North America, 4 U.S. (4 Dall.) 8, 11 (1799).

11 U.S. (7 Cranch) 32 (1812). 
central conception of federal jurisdiction.

There are a number of interrelated ideas associated with the proposition that federal courts have only a limited jurisdiction. One of these was articulated, albeit not for the first time, by Chief Justice Marshall in a companion case to the prosecution of Aaron Burr. ${ }^{b}$ As part of a judiciary "created by written law, and whose jurisdiction is defined by written law," federal courts "cannot transcend that jurisdiction." Put somewhat differently in a later case, "[c]ourts created by statute can have no jurisdiction but such as the statute confers."

Actually, this explanation of limited jurisdiction is an odd basis for differentiating federal and state courts. After all, state judicial jurisdiction is defined by statute or constitution, and we would be surprised to find state courts asserting a power not traceable to one of these sources. Still, state jurisdictional statutes for courts of general jurisdiction are very different from those for federal courts. The former appear to assume the ability of the court to hear any claim recognized by law, whatever the source of that law may be. ${ }^{8}$ Exceptions occur only when some specific limitation in the statute applies-such as a requisite amount in controversy-or when the matter is within exclusive federal jurisdiction.

Federal courts, by contrast, are not presumed to have authority over every case presenting a claim as defined by some law. Indeed, the presumption is precisely the opposite: federal jurisdiction is regarded as nonexistent unless the party invoking it can demonstrate authorization grounded in constitutional and statutory origins. One consequence is that the federal pleading rule requires specific invocation of the jurisdictional base in the complaint. ${ }^{\circ}$ Behind this principle is a still more fundamental notion, applicable to all branches of the federal government. Justice Iredell made the point (as have countless others in our history): "[T]he United States have no claim to any authority but such as the states have surrendered to them: of course, the part not surrendered must remain as it did before."10

Nevertheless, to say that federal powers are derived from the concessions of sovereign states does not explicate the opening statement. Federal courts may be of limited jurisdiction in the same sense that all federal authority is in theory specially delegated. But why are they not

- See Ex parte Bollman, 8 U.S. (4 Cranch) 75 (1807).

- Id. at 93.

7 Sheldon v. Sill, 49 U.S. (8 How.) 441, 449 (1850).

- See, e.g., Gal. Grv. Proc. Code $\S 410.10$ (West 1973); MD. CTs. \& Jud. Proc. Code ANN. § 1-501 (1984); N.Y. Jud. LAw § 2-a (McKinney 1983).

See FED. R. Giv. P. 8(a).

${ }^{10}$ Chisholm v. Georgia, 2 U.S. (2 Dall.) 419, 435 (1793) (Iredell, J., dissenting). 
"general common-law courts," at least with respect to any subject potentially within federal legislative competence? And what does it imply to deny them "a general power to develop their own rules of decision"? One response to these queries has been to invoke Erie Railroad $v$. Tompkins, ${ }^{11}$ which in fact was the other decision besides Hudson cited by the Milwaukee court to establish its proposition. Erie is frequently used to support the principle that possession of subject matter jurisdiction does not imply authority for a federal court to construct independently a rule of decision for a case. ${ }^{12}$ Yet that is also true of any American court. We routinely find a court in one state applying the law of another sovereign, even that of a foreign country, despite the forum court's possessing a general common-law jurisdiction. Something else, much more basic, must be involved.

When a state court decides if it will choose the law of another sovereign, it does so largely as a matter of comity, with few limitations imposed by the federal Constitution. ${ }^{13}$ Two or more states might, with equal claims of right, apply their own law to identical fact situations. ${ }^{14}$ That this may happen is a consequence of the states being sovereign equals. If a question of law is not preempted by superior federal law, the issue is potentially resolvable by the law of several jurisdictions, including foreign ones. States will not insist on applying their own law unless they have an interest in doing so. When interests among states collide, however, resolution almost always depends on whether the forum considers its own concerns sufficiently important to ignore the asserted stake of another sovereign. ${ }^{15}$

As every harried law student knows, the question of choice of law becomes more complicated when it is a federal court making the selection. We resolve these issues according to "the source of the right sued upon." 18 When the source is federal, whether it be the Constitution, a

11304 U.S. 64 (1938).

12 See, e.g., Parratt v. Taylor, 451 U.S. 527, 531 (1981); Walker v. Armco Steel Corp., 446 U.S. 740, 744-45 (1980); United States v. Little Lake Misere Land Co., 412 U.S. 580,591 (1973).

${ }^{13}$ See, e.g., Allstate Ins. Co. v. Hague, 449 U.S. 302, 313 (1981) (Brennan, J., plurality opinion) (state interests need only be "such that choice of [the state's] law is neither arbitrary nor fundamentally unfair").

14 See id. at 307 ("[A] set of facts giving rise to a lawsuit, or a particular issue within a lawsuit, may justify, in constitutional terms, application of the law of more than one jurisdiction.").

15 See id. at 313-20.

16 Flexitized, Inc. v. National Flexitized Corp., 335 F.2d 774, 781 (2d Cir. 1964). See also P. Bator, P. Mishkin, D. Shapiro \& H. Wechsler, Hart and WechsLeR's The Federal Courts AND The Federal System 766 (2d ed. 1973) [hereinafter cited as HART \& WeCHSLER] ("Erie applies . . . to any issue . . . which is governed by state law operating of its own force."). 
treaty, a statute, or federal common law, the answer is, of course, that this law entirely displaces conflicting state law. Federal law may "borrow" from a preexisting body of state law when such appears convenient, but this depends on the discretionary judgment of the federal authority. On the other hand, if the rule of decision is based on state law, the federal court attempts to apply the choice of law rules of the state in which it is located. In these situations the federal court is "only another court of the State,"17 and, as a surrogate for the state judiciary of the forum, it acts for an entity that is a sovereign among other equals. This all follows from another basic element of American federalism: the federal and state establishments are not co-equal sovereigns. As Justice Iredell explained in the course of making his earlier noted observation, "[t]he United States are sovereign as to all the powers of government actually surrendered: each state in the Union is sovereign, as to all the powers reserved."18

The federal government cannot purport to make law in all of the areas that a state might regulate. A federal court could not have "general" common-law powers since its scope of operation is inherently limited by the nature of federal sovereignty. ${ }^{19}$ One might now pose an objection. Under this use of the term "general," neither do state courts possess such jurisdiction: many areas are beyond their authority due to federal preemption. It could be added that given the ever-expanding claims of federal interests, the zones of preemption have become so significant that no state has a "general" lawmaking authority.

If this seems confusing, it is a consequence of a deep ambiguity concerning the respective natures of federal and state common law. A standard account of state law is that "a state legislature acts against the background of the common law, assumed to govern unless changed by legislation."20 Notice how casually the term "the common law" appears in this proposition. It brings to mind the image of a body of law, similar to the way in which courts once referred to the English common law as a corpus of specific rules and principles. Usually, however, the "common law" is taken by us to be a convenient expression for the process by which judges make binding judgments based on nonstatutory

17 Guaranty Trust Co. v. York, 326 U.S. 99, 108 (1945). An immense complication is interjected into this simple scheme because of Congress's constitutional authority to establish federal courts. While federal courts are authorized to determine questions of state law, they are also empowered to act according to federal procedure, which on occasion may affect the outcome of a case.

18 Chisholm v. Georgia, 2 U.S. (2 Dall.) 419, 435 (1793) (Iredell, J., dissenting).

19 Cf. Texas Indus. v. Radcliff Materials, Inc., 451 U.S. 630, 640-42 (1981) (stating that federal common law only exists in narrow areas of unique federal interests).

20 HART \& WECHSLER, supra note 16 , at 471. 
rules. By focusing on the scope of judicial power, we ordinarily argue about such lawmaking authority in terms of the relationship between courts and other branches of government. In each jurisdiction, and in every epoch, there are different and evolving conceptions of the extent to which courts should fashion rules without legislative direction. Nonetheless, at base the Anglo-American tradition makes an assumption that is captured by the reference to the "background" nature of common law. That is, there are rights and duties that exist notwithstanding the lack of action by a legislative body with respect to the area in question. When these rights and duties are nonconstitutional in their origin, a legislature may override what the court declares; but that merely alters the particular rule, not the general authority to make rules.

The common-law power of federal courts-as the opening quotation implies-is usually thought to be of a different genus than that of state judiciaries. Again, a standard account of federal law is implicated: "Congress acts . . . against the background of the total corpus juris of the states in much the way that a state legislature acts against the background of the common law, assumed to govern unless changed by legislation."21 Readers will notice that the second part of the last sentence was quoted above in describing state common law. And here is the root of our puzzle. It is understandable to hold that state law is a "background" jurisprudence if one merely means that all federal power is derived from state delegations. Once we are in an area in which the federal government has undisputed authority, though, we might also claim something along these lines: "the federal legislature acts against the background of the federal common law, assumed to govern unless changed by legislation."

To make this contention would be to swim against a strong doctrinal current, which denies that "the existence of congressional authority under Art. I mean[s] that federal courts are free to develop a common law to govern those areas until Congress acts." ${ }^{22}$ Apart from cases in which Congress has conferred authority on courts to develop substantive rules of decision, the modern Supreme Court has restricted federal common law to "such narrow areas as those concerned with the rights and obligations of the United States, interstate and international disputes implicating the conflicting rights of States or our relations with foreign nations, and admiralty cases." ${ }^{23}$ Federal common law is often

21 Id.

${ }^{22}$ Texas Indus. v. Radcliff Materials, Inc., 451 U.S. 630, 641 (1981).

${ }^{23}$ Id. (footnotes omitted). 
referred to as "specialized."24 It is invoked as a "necessary expedient," 25 in a "few and restricted" instances, ${ }^{26}$ and only if the federal court feels "compelled"27 to do so.

In short, the difference between the "general" jurisdiction of state judiciaries and the "limited" jurisdiction of federal courts lies in the conception of the common law appropriate for the respective systems. Both levels of government harbor some enmity toward the process of common-law adjudication itself, which largely stems from the belief that judicial lawmaking encroaches upon the province of the other branches of government. For federal courts, there is yet another aspect of the matter, which is an apparent preference-shared by many in the federal and state judiciaries-for maintaining power and responsibility at the state and local levels. Like the separation of powers issue just raised, this federalism concern is partly inspired by the attitude that diffusion of decisionmaking is more likely to promote democratic values. It also reflects the traditional notion that numerous sources of law will produce a greater diversity of doctrines, with all of the concomitant advantages that are supposed to spring from such experimentation.

But this explanation is problematic. The exercise of power by Congress (not to mention the Executive) can intrude pervasively on state and local institutions. Looking only at the values of federalism, why should it make any difference if a federal court were to make a common-law rule in an area over which Congress has competence? What requires it to await specific authorization from the national legislature? Usually the response to these types of inquiries is along the following lines: "[T]he political structure . . . gives the states per se very significant power in the Congress-to a degree hardly paralleled in the judicial structure."28 One might doubt that the "states" as such are inevitably potent forces in Congress, or that Congress is even an institution especially responsive to popular will. Those issues will be put aside, as this is not the place to rehearse the sizeable literature on the question of congressional and executive autonomy. ${ }^{29}$ Even assuming

24 See, e.g., Friendly, In Praise of Erie-and of the New Federal Common Law, 39 N.Y.U. L. REV. 383, 405 (1964).

28 Milwaukee v. Illinois, 451 U.S. 304, 314 (1981) (quoting Committee for Consideration of Jones Falls Sewage Sys. v. Train, 539 F.2d 1006, 1008 (4th Cir. 1976) (en banc)).

26 Wheeldin v. Wheeler, 373 U.S. 647, 651 (1963).

27 Milwaukee v. Illinois, 451 U.S. 304, 314 (1981).

${ }^{28}$ Mishkin, The Variousness of "Federal Law": Competence and Discretion in the Choice of National and State Rules for Decision, 105 U. PA. L. REv. 797, 800 n.12 (1957).

29 For an example of this debate, see J. ChOper, Judicial Review and THE National Political Process 12-47 (1980). 
that the people in fact control their elected representatives, in a more or less direct fashion, why should that affect the federal common law? The same relationship, we may notice, exists at the state level; the primary popular check on state courts' common-law powers are the legislatures. Do the people inherently have a lesser ability to control Congress than they do their state legislatures? Offhand, answering that question seems impossible. A variety of variables would figure in determining how completely legislators can be insulated from popular pressures, and surely these variables must fluctuate over time. Moreover, if we were really serious about this business of popular control, why should the system permit any federal common law not expressly authorized by Congress?

There is plainly a difference between the political structure upon which state legislatures are erected and the structure supporting the Congress. Legislatures must be apportioned more or less equally by population, a feature absent in the Senate by virtue of the Great Compromise. Perhaps this is a justification for restricting federal common law, but it is hardly one that rests upon a commitment to majoritarianism. A greatly expanded federal common law would remain subject to congressional control (and the disproportionate influence of some states in the Senate). Nevertheless, it is undeniable that relatively weaker forces in Congress would lose a measure of power if they were required to marshal a legislative majority to override a common-law decision. It is far easier generally to block legislation than to enact it.

Further muddying the waters is the necessity to factor judicial responsiveness to popular will into the analysis. And at some point one has to contemplate why "accountability," in the sense of following the people's dictates, is the appropriate ideal. In any event, why would we not expect federal courts to be sympathetic to the need for local lawmaking? Indeed, the last question is ironic since the limitations on federal common law largely have been imposed by the federal judiciary itself.

When all is said and done, the answer to these questions is not going to be found in a logical construction of federal jurisdiction. Rather, the matter has a great deal to do with the balance of political forces in the society, the degree of attention that courts wish to devote to certain areas, and a range of other elements that form the judicial personalities of an era.

This essay is composed of two parts (this being the first part) that begin an inquiry into the early evolution of federal common law. It examines how our current understanding of the constrained nature of federal common law came into being by investigating the context of its 
origins. To this end, we will concentrate on the period leading up to and surrounding the Supreme Court's decision in the case that has come to be viewed as the earliest expression of the principle that federal courts have only limited common-law powers: United States v. Hudson. ${ }^{30} \mathrm{Hudson}$, we shall see, is a strange decision to support such a broad implication. It is not merely that the case dealt with the narrow area of federal common-law crimes (more specifically, seditious libel). The Milwaukee Court is quite right in thinking that the majority behind Hudson meant its principles to apply to all areas in which federal courts fashioned common law. But in the process of employing those principles, the Court takes $H u d s o n$ very much at face value, without examining the peculiar historical period in which it arose and the ideological assumptions that informed its premises.

That Hudson is read as support for such a central conception of federal court power is not the only reason for focusing on the case and its times. Few would care to alter a fundamental legal principle merely because it is shown that its initial appearance was in some manner questionable. What can be demonstrated by Hudson, and more particularly the legal history of the years before it, is that a very basic aspect of our constitutional structure was largely defined by the results of a bitter partisan contest. In the course of the long argument, which stretched over approximately twenty years, the debate over the common-law powers of federal courts took some rather dramatic turns. Even the concept of what was in dispute-the definition of "common law"-was distorted and manipulated by political actors. This will become clearer in the second half of this essay, and we will see how the term "common law" meant various things depending on what a given speaker was attempting to accomplish with its use.

There was no coherent concept in the early nineteenth century of "federal common law" as we now make use of that expression. A great deal of verbal effort was expended then in discussing the "common law" in relation to the powers of federal courts. Nonetheless, the idea of what "common law" entailed corresponded to the ideological orientations of particular advocates, and more generally, was colored by natural law conceptions. Throughout the first three Administrations of the United States, fierce controversy surrounded the actual and purported authority of federal courts. Although the various contestants in this

so 11 U.S. (7 Granch) 32 (1812), cited in Parratt v. Taylor, 451 U.S. 527, 531 (1981); Carlson v. Green, 446 U.S. 14, 38 (1980) (Rehnquist, J., dissenting); Keeble v. United States, 412 U.S. 205, 215 (1970) (Stewart, J., dissenting); United States v. Standard Oil Co., 332 U.S. 301, 313 (1947); D'oench, Duhme \& Co. v. FDIC, 315 U.S. 447, 469 (1942) (Jackson, J., concurring). 
struggle produced an assortment of theories to justify their respective versions of federal jurisdiction, a cogent explanation of federal common law (as nonconstitutional, judicially-created law that was binding on states and subject to authoritative review by the Supreme Court) never emerged in the Hudson era. This is not simply a reflection of differing terminology. Instead, the linguistic departures between their age and ours are indicative of fundamental incongruities. Compounding the analytic difficulties is the fact that various public figures in the early nineteenth century provided answers to questions about federal judicial authority in forms that seem directly applicable to our own arguments over federal common law. For the most part, however, they were asking entirely different questions, and if we employ their answers it should be with an awareness that a kind of game is being played.

The aim of the Part One of this essay is to place the matter of federal common-law powers within the context of the larger political history of the Hudson era. By the end of the 1790's, the issue had become one of furious contention between the two major political parties. Rather than simply an interesting exchange of scholarly perspectives on a technical point of law, the disagreement between the Republicans and the Federalists over the common law reflected very different visions of government and society. For both sides, resolving the dispute depended upon what they considered to be some of the most basic ingredients of constitutional theory. To appreciate this dimension of the problem, we must have some impression of the constitutional discourse carried on before Hudson-and how sharply it diverges from today's dialogue.

Part One of this essay starts the inquiry, in section I, by analyzing the peculiarities of the Hudson decision itself. This analysis scrutinizes various aspects of the case and should cause us to begin questioning the reliance on Hudson for the broad principle that federal courts have only limited common-law decisionmaking powers. In section II the discussion turns to a sketch of the political history in the two decades prior to Hudson. We will see how the partisan clashes of this time directly influenced the intellectual and social atmosphere in which the debate over the appropriate role of the national courts took place. It will become evident that political interests and ambitions were inseparable from the efforts to distill a principled reading of the Constitution. Finally, section III of Part One discusses chronologically the political events of the time as they related to the question of federal courts' common-law authority. First, it examines the early cases in which federal courts asserted common-law criminal jurisdiction. Then we will see how the argument extended beyond the courts to other settings-in 
particular, the legislative activity surrounding the Alien and Sedition Acts, and the debates over the enactment and subsequent repeal of the Judiciary Act of 1801 . By viewing the issue in these contexts, we examine how the topic of federal common-law powers evolved and the way in which the controversy over the extent of such power matured.

After Part One has related the extent to which the issue of federal common-law powers was associated with other political affairs of the period prior to Hudson, Part Two looks at the question of why specific arguments concerning federal courts were formulated in the way that they were. The partisan clashes of the 1790's were not just petty fights among aspiring politicians. Rather the struggles over federal common law reflected aspects of wider ideological differences.

Part Two presents a series of developments that shaped the dispute over common-law adjudication by the federal courts. Some of these developments are analyzed at the level of the political philosophies and legal theories that informed contemporary constitutional discourse. These include the analytic confusion surrounding prepositivist conceptions of law and the awkward fit of older ideas about territorial sovereignty into a federal system. Others relate to the Constitution itself, particularly the history of its framing and the positions that its proponents took to achieve ratification. Although the inquiry cannot provide a complete explanation of the development of constitutional principles of this period, the idea is to demonstrate that the theory of federal common-law jurisdiction underlying Hudson was essentially incomplete.

To urge that the Hudson doctrine lacked in ultimate coherency is not to deny that people of the period thought they saw something important and persuasive in its mandate. Yet if we are to use Hudson today to support principles relevant to our own decisions about federal common-law jurisdiction, it ought to be with an awareness that the Hudson Court confronted entirely different problems than we face today. In the end, then, this essay is not so much about history itself as it is the use of history by the courts. Part Two concludes by addressing this theme and questioning the coherency of modern renditions of the common-law functions of federal courts. The modern understanding of federal common law, as expressed in judicial decisions, is little more than a disconnected assortment of bits from a little understood past.

\section{United States v. Hudson: THe Decision}

By the time Hudson was decided in $1812,{ }^{31}$ a majority of the Su-

s1 Granch's report of the case gives the date of decision as February 13, 1812, with Justice Washington recorded as being absent. 11 U.S. (7 Cranch) at 32 . The 
preme Court consisted of Republican appointees. Identifying the party affiliations of Justices may seem odd to those who are aware that Presidents have come to learn about the unpredictable consequences of lifetime judicial tenure. The simple but accurate explanation is that the period before Hudson was unlike our own. Judicial independence did play a role in affairs, as is demonstrated by the Supreme Court's refusal in the summer of 1793 to answer Washington's questions on critical foreign policy issues. ${ }^{32}$ For much of this time, however, the mixture of judicial activity with partisan politics provided cause for genuine concern on the part of the party in opposition, and was not merely the product of paranoid perceptions.

Hudson arose out of indictments brought in 1806 and 1807 before the federal circuit court for the District of Connecticut. Indicted by a grand jury picked by a Republican marshall ${ }^{33}$ were a Federalist state judge, ministers, and newspaper editors, all of whom had made various statements derogatory of Jefferson. ${ }^{34}$ In charging the grand jury, the Republican federal district judge, Pierpont Edwards, advised that the common law of seditious libel could form the basis of an indictment. ${ }^{\text {35 }}$ This was especially peculiar conduct for the judge since, as is developed below, ${ }^{36}$ Republicans had spent a great deal of political effort in the prior ten years denying the existence of federal common-law crimes. News of the indictments caused a stir among certain Republican circles since there was more than a small appearance of hypocrisy. ${ }^{37}$

minutes of the Court for that date, however, show no record for Hudson; instead, the minutes for March 14, 1812 indicate that on that day judgment was entered and that all Justices were present. Likewise, Cranch's report says that the "opinion was delivered (on the last day of the term, all the judges being present)," 11 U.S. (7 Cranch) at 32, which would have been March 14.

32 See G. Thomas, American Neutrality in 1793: A Study in Gabinet Government 145-50 (1967) (describing the refusal of the Supreme Court to give extrajudicial advice to the President).

ss Jefferson himself admitted as much. See Letter from Thomas Jefferson to Wilson Cary Nicholas (June 13, 1809), reprinted in 11 The Works of ThOMAS Jefrerson 111 (P. Ford ed. 1905).

34 See 2 W. Crosskey, Politics and the Constitution in the History of THE UNITED STATES 771-72 (1953).

35 See id. at 771 (citing-the Witness (Litchfield, Conn.), Apr. 30, 1806).

so See infra text accompanying notes 371-93, 420-37, 477-505 \& 530-33.

s7 See, e.g., 20 ANNALS of CoNG. 75-89 (1809) (discussion on the House Floor over a motion by Representative John Randolph to appoint a committee to investigate the prosecution). Randolph noted his astonishment that the cases "had created so little sensation in the House or in the nation." Id. at 86. Though there was talk about the apparent political motivations behind the prosecutions-with Randolph observing that "such is the difference between men in power and men out of power," id. at 76-the speakers were unwilling to blame Jefferson or then President Madison for instigating the indictments. What Randolph could not understand was why the President "should permit an attorney for the United States to hold his office one second after having 
That Republicans were bringing common-law criminal actions in federal court was only one of the strange aspects of the case. The usual account of Hudson is that Jefferson, upon hearing of the prosecutions, ordered them dismissed at once. ${ }^{38}$ Evidently this is not wholly accurate since two of the prosecutions-against Barzillai Hudson and George Goodwin-were taken to the Supreme Court (no trial was ever held) on a certificate of division between the District Judge and the Circuit Justice, Brockholst Livingston. ${ }^{39}$ Moreover, there is considerable evidence indicating that Jefferson ordered some of the dismissals only after news of the nature of the alleged libel reached him, and he realized that the defendants could probably prevail on a defense of truth. ${ }^{40}$ In any event, the charges against Hudson and Goodwin-their newspaper had claimed that Jefferson had conspired to grant Napoleon two million

commenced a prosecution in a court of common law for libel." Id. at 77.

Federalists did not make the case into a major issue; they did, however, point out the obvious partisan overtones. The district judge, the marshall, Joseph Wilcox, and one of the prosecutors, Alexander Wolcott, were all prominent members of the Republican establishment in Connecticut. Edwards and Wolcott had been principal organizers of the 1800 Jeffersonian presidential campaign in that state, and both received their federal appointments during Jefferson's Administration. On the role of these individuals in Republican politics, see G. Clark, A Hrstory of Connecticut 344, 347, 350 (1914); R. Purcell, Connecticut in Transition 217, 232, 241, 273-74 (1918).

s8 See G. Haskins, Foundations of Power: John Marshall, 1801-1815 (Part One) 355 (1981); 1 C. Warren, The Supreme Court in United States HistoRy 435-36 (1932). In an 1809 correspondence, Jefferson asserted his lack of involvement: "Certain it is, that the prosecution had been instituted, and had made considerable progress, without my knowledge, that they were disapproved by me as soon as known, and directed to be discontinued." Letter from Thomas Jefferson to Wilson Cary Nicholas (June 13, 1809), supra note 33. Professor Crosskey has demonstrated, however, that a letter from Jefferson on February 11, 1807 indicates the President's knowledge and approval of the prosecutions. 2 W. Crosskey, supra note 34, at 772-73. Crosskey suggests that the prosecutions started as a means to harass prominent Connecticut Federalists. The state was still in Federalist hands, and only recently several Republicans had been subjected to criminal actions under Connecticut's sedition act. Id. at 770-71. Subsequently, the Jeffersonians saw Hudson as a vehicle for an authoritative repudiation of federal common-law jurisdiction: A series of unusual postponements in the case does offer some evidence that the proceedings were delayed until the Republicans had a safe majority on the Supreme Court. See id. at 775-82.

so See 2 W. Crosskey, supra note 34 , at 781 .

40 One of the indictments related to a statement made from the pulpit by Reverend Azel Backus, who had brought up the "Walker affair," which involved Jefferson's alleged attempt to seduce the wife of his former best friend, John Walker. As the evidence compiled by William Crosskey tends to establish, Backus had a good chance of proving his remarks to be truthful; further, the sequence of events in the Backus prosecution indicates that the dismissal was probably prompted by Jefferson's realization of what the slander entailed. See 2 W. Crosskey, supra note 34, at 779-81; see also L. Levy, Jefrerson and Civil Liberties: The Darker Side 65-66 (1963). Jefferson claimed that "the clergyman . . . solemnly declar[ed] he had never uttered the words charged." Letter from Thomas Jefferson to Wilson Cary Nicholas (June 13, 1809), supra note 33. 
dollars ${ }^{41}$-went before the Court with all the appearances of a feigned controversy. No oral argument was held as Attorney General William Pinkney and defense counsel Samuel W. Dana declined to proceed. ${ }^{42}$ Instead of dismissing the case for failing to present a live dispute, the Court proceeded to a summary decision announced by Jefferson's first appointee, William Johnson. ${ }^{43}$

One might cynically conclude that Hudson was written deliberately to mislead later generations. Whatever the majority intended, in some respects Hudson did accomplish that end. At a minimum, Justice Johnson evidently tried to produce a sweeping decision. In Johnson's own words, he "broadly"44 stated the question presented as "whether the circuit courts of the United States can exercise a common-law jurisdiction in criminal cases. . . . [the resolution of which would] apply to every case in which jurisdiction is not vested in those Courts by statute."45 This was a "simple, obvious" issue, Johnson wrote, one "long since settled in public opinion." other case, for many years, has this jurisdiction been asserted; and the general acquiescence of legal men shows the prevalence of opinion in favor of the negative of the proposition." 47

At least some have taken Hudson to state accurately the history

4 See J. McClellan, Joseph Story and the American Constitution 171 n.31 (1971). Jefferson had asked Congress in 1805 to appropriate a secret fund to bribe the French government into pressuring the Spanish to relinquish West Florida. See J. Broussard, The Southern Federalists 1800-1816, at 70 (1978).

12 See 2 W. Crosskey, supra note 34, at 782. An odd note on Pinkney's involvement with the case was recorded by Henry Wheaton: "I am told that Mr. Pinkney had formed, and frequently expressed, a very decided opinion that the courts of the Union possessed a common law jurisdiction; though I have not been able to learn what were the grounds of this opinion, or the limitations he would have admitted . . . H. Wheaton, Some account of the Life, Writings, and Speeches of William PinkneY 114 (Philadelphia 1826).

ts See $2 \mathrm{~W}$. Crosskey, supra note 34, at 782. It is possible that Justice Johnson did not actually write the opinion. In the early years of the Marshall Court, opinions typically were delivered by the most senior Justice present-even if he was not the author. See White, The Working Life of the Marshall Court 1815-1835, 70 VA. L. REv. 1, 36 (1984). If the seniority system were operating, however, it would at least imply that Marshall and Washington dissented since both were senior to Johnson. As Johnson was the most senior of the remaining justices and was surely in the majority, it appears reasonable to think that Johnson may have been the author, especially since the reasoning in Hudson accorded with his overall philosophy. An interesting feature of the Marshall Court's processes is that the other Justices in the majority would not necessarily have endorsed the specific opinion delivered by Johnson. See id. at 38-39. But this is all quite speculative as it is difficult to determine how well the seniority principle was operating in 1812 or how it was modified in the rare cases of nonunanimous results. See id. at 37.

14 Hudson, 11 U.S. (7 Cranch) at 32.

4 Id.

4s Id. at $32-33$.

47 Id. at 32. 
involved-that "the United States has never had a federal common law of crime." 48 The matter of the status of federal common-law crimes was actually much more involved than Johnson's opinion indicates. For one thing, the decision was not unanimous-although the vote was not reported, it was most likely a four-to-three split. ${ }^{48}$ More critically, prior to the Republican ascension to the federal judiciary beginning in the first Jefferson Administration, the virtually unanimous opinion of federal judges-all of whom were Federalists-was that indictments could be sustained in federal court under the common law for crimes against the United States. ${ }^{50}$ According to Justice Story, "every Judge that ever sat on the Supreme Court Bench, from the adoption of the Constitution until 1804," with one exception, looked favorably upon federal courts assuming this jurisdiction. ${ }^{\text {s1 }}$ Three of the Justices who endorsed federal common-law jurisdiction, Wilson, Ellsworth, and Paterson, had been prominent members of the Convention; in fact, the latter two served on the Senate committee that drafted the Judiciary Act of $1789 .{ }^{.2}$ Only the notorious Justice Samuel Chase is known to have (1982).

48 G. Calabresi, A Common Law for the Age of Statutes 245 n.39

${ }^{49}$ See 2 W. Crosskey, supra note 34, at 782 (identifying the dissenters as Marshall, Story, and Washington). The opinion indicates that a "majority" accepted its views. Hudson, 11 U.S. (7 Cranch) at 22. A year after Hudson, a judge sitting on circuit in Charleston wrote about the case: "I am confident that Judge Washington alone, if any one, at that time dissented from the opinion." Trial of William Butler for Piracy 12 (1813) [original pamphlet in Harvard Law School Library; copy on file with the University of Pennsylvania Law Review]. Although the publication actually has no author indicated, Morton Horwitz attributes authorship of this otherwise unreported opinion to Justice William Johnson. See M. Horwitz, The Transformation of AMERICAN LAw 1780-1860, at $271 \mathrm{n} .39$ (1977). While Charleston was part of Johnson's circuit assignment, the district judge could have held the proceedings by himself. Extensive research, including a reading of all extant Charleston newspapers from the period, has failed to uncover any records for the case. In any event, the statement about Hudson is unreliable. For example, Justice Story's views are not even mentioned; as will be developed in Part Two, he almost surely supported jurisdiction in Hudson.

so See Ex parte Grossman, 267 U.S. 87, 114-15 (1925); M. HorwITZ, supra note 49 , at 9; L. LeVY, supra note 40 , at $201 \mathrm{n} .72 ; 1$ C. WARREN, supra note 38 , at 433-34; Von Moschzisker, The Common Law and Our Federal Jurisprudence (pt. 1), 74 U. PA. L. REv. 109, 123 (1925). The district court in Hudson charged the grand jury that it was "the sentiment of a great majority" of the Supreme Court that indictments for common-law libel could be brought in federal court. Reprinted in The Witness (Litchfield, Conn.), Apr. 30, 1806, quoted in 2 W. CRosskey, supra note 34, at 771.

51 Life AND LetTers of JosePh Story 299 (W. Story ed. Boston 1851).

s2 See Warren, New Light on the History of the Federal Judiciary Act of 1789, 37 Harv. L. Rev. 49, 50 (1923). According to Warren, "[i]n the early years of the Court, Chief Justices Jay and Ellsworth, and Judges Cushing, Iredell, Wilson, Paterson and Washington had each delivered opinions or charges in support of the existence of such jurisdiction." 1 C. WARREN, supra note 38, at 433; See, e.g., Ex parte Grossman, 267 U.S. 87, 115 (1925). On the views of Wilson, Jay and Iredell, see infra text accompanying notes 181-193; for a discussion of Marshall's position, see Part Two of 
thought the contrary. ${ }^{53}$

Evidence exists showing that Jefferson's Administration utilized federal common-law prosecutions aside from $\mathrm{Hudson-for} \mathrm{instance,}$ when it enforced the embargo. ${ }^{54}$ For the most part, however, Republicans had opposed such federal proceedings for years, and this was not simply because those in their camp were the subjects of the indictments. Pragmatism of a different sort played a leading role in their reaction to the Federalist assertions about the legality of federal common-law crimes. The issue of federal common-law powers implicated the much larger question of how much power was possessed by the national government. The Republican viewpoint on that issue had been forged while they were an emerging opposition. Justice Johnson's opinion in Hudson, appearing years after Jefferson's party became dominant, succinctly expressed the partisan Republican stance about federal power that had been developed in the political wars of the 1790's.

Justice Johnson made no pretense that his opinion in Hudson followed from an analysis of precedents or a study of the Framers' intent. It was pure assertion, based largely on what he referred to as "public opinion" and "the general acquiescence of legal men." Vs Viewed in

this Article, 133 U. PA. L. Rev. 1231, Appendix B. Like Charles Warren, Leonard Levy has claimed that Paterson "accepted jurisdiction of common law crimes," $L$. Levy, Legacy of Suppression: Freedom of Speech and Press in Early AmeriCAN HISTORY 241 (1960); but after reviewing the evidence, John E. O'Connor was unable to find "incontrovertible proof of [Paterson's] action on a common-law indictment in a federal jurisdiction." J. O'ConNOR, William Paterson, LAWYer and StaTESMan 1745-1860, at 330 n.55 (1979). Nevertheless, O'Connor surmised from "Paterson's broad interpretation of federal authority in his grand jury addresses . . . [and the Justice's] defence of the common law in New Jersey [that he] would have admitted common law indictments had they been presented to him." Id. While it is true that no records have been found showing Paterson as the judge in a federal commonlaw prosecution, he did record his firm acceptance of the jurisdiction. See infra text accompanying notes 400-403. For an illustration of Ellsworth's philosophy in support of common-law jurisdiction, see his Grand Jury Charge reprinted, infra, in the Appendix. Finally, Justice Washington is the clearest case: "I have often decided," he wrote, "that the federal courts have a common-law jurisdiction in criminal cases . . . " United States v. McGill, 26 F. Cas. 1088, 1090 (C.C.D. Pa. 1806) (No. 15,676). This encompassed "many crimes and offences against the authority of the United States, which have not been specifically defined by law." Id.

ss See United States v. Worrall, 28 F. Cas. 774 (C.C.D. Pa. 1798) (No. 16,766) (Chase, J., dissenting); see also infra notes 324-32 and accompanying text.

44 See H. Johnson, Foundations of Power: John MARShall, 1801-1815 (PART Two) 638-39, 640-41 (1981). In 1802 Jefferson's Attorney General Levi Lincoln ordered common-law prosecutions against individuals in Kentucky who allegedly forcibly rescued from jail a man accused of Indian murders. After the United States Attorney protested to the Administration, averring to "the public heat [the Republican] party had raised about the common law," the indictment was dismissed. See $M$. Tachau, Federal Courts in the Early Republic 130-131, 131 n.27 (1978) (quoting the memoirs of the United States Attorney, Joseph H. Daveiss).

ss Hudson, 11 U.S. (7 Cranch) at 32. See also Presser, A Tale of Two Judges: 
light of the political transition that had occurred with the success of the Jeffersonian campaign, those remarks can be construed as a thinly disguised reminder of which side had won-in the public's eyes-a longstanding political struggle. Nonetheless, Johnson's opinion has the formal appearance of an easy deduction from first principles, starting with what may seem an uncontroversial observation: "The powers of the general Government are made up of concessions from the several states-whatever is not expressly given to the former, the latter expressly reserve." ${ }^{\text {"Bs }}$ From this view of the vertical distribution of power in a federal structure, Hudson proceeds to quite a different contention, one that modern readers would see as rooted in the separation of powers at the federal level:

The judicial power of the United States is a constituent part of those concessions; that power is to be exercised by courts organized for the purpose; and brought into existence by an effort of the legislative power of the Union. Of all the courts which the United States may, under their general powers, constitute, one only, the supreme court, possesses jurisdiction derived immediately from the constitution, and of which the legislative power cannot deprive it. All other courts created by the general government possess no jurisdiction but what is given them by the power that creates them, and can be vested with none but what the power ceded to the general government will authorize them to confer. ${ }^{57}$

A two-step delegation is envisioned: certain powers were transferred by the original compact from the states to the federal government; the federal courts were recipients of the judicial aspects of those powers, but the lower federal courts actually received only so much as Congress granted them. Regarding "cases similar to the present"-probably a reference to the crime of seditious libel-" it is enough that such jurisdiction has not been conferred by any legislative act ...." Johnson did not specifically address whether the Judiciary Act of 1789 had in fact conferred on the circuit courts jurisdiction over common-law crimes by virtue of granting them "exclusive cognizance of all crimes and offences cognizable under the authority of the United States, . . . except where this act otherwise provides, or the laws of the

Richard Peters, Samuel Chase and the Broken Promise of Federalist Jurisprudence, 73 Nw. U.L. REv. 26, $71-72$ (1978) (explaining that the federal common law of crimes was more a political than a legal problem).

bo Hudson, 11 U.S. (7 Cranch) at 22.

${ }^{87}$ Id.

SB Id. 
United States shall otherwise direct."

Even assuming that the first step in Johnson's reasoning is correct (that all federal powers are derived from the states, as opposed to the American people), the separation of powers conclusion does not necessarily flow from it. One could maintain, as Justice Story did four years later in Martin v. Hunter's Lessee, ${ }^{80}$ that article III's grant-utilizing the language "shall be vested"-was meant to be mandatory on Congress. ${ }^{61}$ Although Story's interpretation no longer commands adherents, ${ }^{62}$ and was implicitly rejected by the first Congress in drafting the $1789 \mathrm{Act}^{63}$ it reminds us of a now accepted distinction between arguments based on federalism and others springing from intergovernmental relations at the federal level. That Johnson would blur the two was a natural product of the way in which the matter of federal common-law powers had been played out in the years prior to Hudson.

\section{The Setting for Decision: Politics of the Early REPUBLIC}

\section{A. The Political Climate of the Immediate Post-Confederation Period}

For any political history of the early Republic, the issue of the common-law powers of the federal judiciary is an indispensable chapter, a part of the turbulent years dominated by the partisan contest between entrenched Federalists and the emerging Republican party.

69 The Judiciary Act of $1789, \S 11,1$ Stat. 73,79 (current version at 28 U.S.G. $\S$ 1652 (1982)). An early authority thought the Act had conferred such jurisdiction, see W. Rawle, A View of the Constitution of the United States of America 271 (2d ed. Philadelphia 1829) (1st ed. Philadelphia 1825), as did Justice Story, see United States v. Coolidge, 25 F. Cas. 619, 619-20 (C.C.D. Mass. 1813) (No. 14,857). Charles Warren also supported the existence of common-law criminal jurisdiction under the Act, noting that Congress had eliminated the qualifying clause, "and defined by the laws of the land," from the provision in $\$ 11$ quoted in the text. Warren, supra note 52, at 77. Julius Goebel, on the other hand, considered this issue open to doubt and thought that the Congress's excision was explainable on other grounds. See J. Goebel, History of The Supreme Court of THE UNITEd States: ANTECEDENTS AND BEGINNINGS TO 1801, at 495-96 (1971).

6014 U.S. (1 Wheat.) 304 (1816).

-1 Id. at 351-54. While Justice Story was writing for a majority, his view on mandatory article III jurisdiction was dictum, which he appeared to repudiate shortly thereafter. See White v. Fenner, 29 F. Cas. 1015 (C.C.D. R.I. 1818) (No. 17,547). Nevertheless, this view has had supporters at various times. See 1 W. GrosskeY, supra note 34, at 615-17; Warren, supra note 52, at 68.

-2 See Sager, Foreword: Constitutional Limitations on Congress' Authority to Regulate the Jurisdiction of the Federal Courts, 95 HARv. L. Rev. 17, 25 n.22 (1981).

es See C. WRIGHT, supra note 2, at 4. 
Hudson was a piece in an elaborate mosaic of issues. While numerous elements comprised the overall picture, there was an essential image on the minds of everyone with an interest in America's political and social future. That image was the nature of the Union itself. But it was an image of associated concerns, not a defined portrait of the new nation, and the form of the image depended very much on the mind of the viewer. One cannot read the pamphlets, letters, recorded speeches, and other writings from this period without being left with the sense that the United States was a concept in formation, not an agreed-upon state of affairs. Vehement disagreements existed over what the Constitution meant, and though traces of the clash persist, they bear little resemblance to their origins. The question of the federal judiciary's relation to the common law took on a definite cast due to the character of the political clashes in this country during the first twenty years of its existence.

A key aspect of political life was a constitutional argument over the relationship between the new federal government and the existing states. Americans were entirely unaccustomed to the idea of dominance by a central government formed from the populace living on their own soil. Most had long associated remote government with tyranny, and political office with personal ambition. Nevertheless, it would be wrong to assume that "democracy" in our modern sense of popular control of the state was uniformly seen as the antidote for excessive government. To the American elite of the Revolutionary period, democracy usually signified "the lowest order of society . . . [which] was generally associated with the threat of civil disorder and the early assumption of power by a dictator." From the time of ratification to the close of the century American politics were "peculiarly violent." nation with the leading actors of the era tends to gloss over the fact that the vast majority of the people lived a simple, isolated rural life hardly varying from that of a century before. ${ }^{66} \mathrm{Few}$ wanted any government at all, much less a federal one. George Haskins succinctly describes their social world: "[L]arge sectors of the population were improvident and antisocial; they did not take kindly to any form of authority, which to them inevitably meant order, limitations on freedom of action, mutual obligations, and worst of all, taxes."167 (1967).

See Howe, Republican Thought and the Political Violence of the 1790s, 19

AM. Q. 147, 147 (1967).

See G. HASKINS, supra note 38 , at $42-43$.

${ }^{67} I d$. 
We need to be conscious of the rudimentary level of eighteenth century American society when thinking of the constitution planned by the Framers, who were hardly typical representatives of the people whose government they charted. For most of the Framers, the events of the Confederation had brought the young country to the brink of premature death, primarily because power had been placed in the hands of those who were thought not competent to wield it. ${ }^{88}$ State constitutions of the post-Revolutionary period, they believed, shared a uniform defect "in that the balance of power was destroyed through a preponderance in favor of the legislature." ${ }^{\prime \prime 9}$ Yet it was not so much the constitutional structures then in place that were seen as being at fault. Rather, in Gordon Wood's words, it was "the large number of obscure, ignorant and unruly men," after the Revolution. ${ }^{71}$ This new leadership had introduced a host of popular measures abhorrent to the sensibilities of the dominant classes, including property confiscations, issuance of paper money, tender laws, and a variety of devices to prevent debt collections. ${ }^{72}$ In addition to these problems, America's history of extra-governmental action, through various forms of mob activity, was continuing with vigor. ${ }^{73}$ The fresh memory of Shay's Rebellion was not the least of the weights that the Framers carried with them to Philadelphia. ${ }^{\text {"4 }}$

What came from the Convention in the form of our Constitution was, in the context of those days, an "intrinsically . . . aristocratic document." ${ }^{\prime \prime 6}$ Throughout its main parts, power was distributed-as the Antifederalists bitterly recognized ${ }^{26}$ - so as to locate federal author-

es See G. Wood, The, Creation of the American Republic 1776-1787, at 424-25 (1969).

69 W. Carpenter, The Development of American Political Thought 71 (1930).

$70 \mathrm{G}$. Wood, supra note 68 , at 507.

71 See id. Prior to the Revolution, political power was largely monopolized by small groups of aristocratic men. During the post-Revolutionary War period, elections became more important, and individuals perceived as demagogues were able to obtain positions of power. See R. Ellis, The JefFersonian Grisis: Courts and Polrtics IN THE Young RePUBlic 268-69 (1971).

72 See G. Woon, supra note 68, at 404.

${ }^{73}$ See id. at 319-28. As Wood explains, riots motivated by both economic and political concerns were common occurrences during the colonial period and the early years of the Republic. State governments were often too weak to respond, and thus counter-mob organizations were formed, escalating the public disorders of the Confederation. Id. at 320 .

${ }_{74}$ See Corwin, The Progress of Constitutional Theory Between the Declaration of Independence and the Meeting of the Philadelphia Convention, 30 AM. HIST. REv. 511, 533-34 (1925).

${ }^{75} \mathrm{G}$. Wood, supra note 68 , at 513.

${ }^{76}$ See, e.g., Letters of Cato (V), reprinted in 2 The Complete ANTI-FederalIST 116-19 (H. Storing ed. 1981). As Cato complained, "It is a very important objec- 
ity in the hands of a few. What the Antifederalists failed to perceive was that the Framers were well imbued with an ideological distrust of concentrated power, and accordingly "adopted every conceivable device to protect the people from their rulers."77 Federal power would be dominated by a minority, but their power was dispersed and checked. These were checks born of pragmatic compromises at every turn, ${ }^{78}$ a process unlikely to produce a system of government whose principles of operation would be obvious and uncontroversial. Large areas of critical importance were deliberately left to later resolution by the imprecision of the language employed.

Virtually from the moment the Constitution was released by the Convention, conflicting views emerged over its essential elements. When the new government formed, it was immediately apparent that there were fundamental rifts in opinion as to the powers that had been transferred to the central government. ${ }^{79}$ An opposition gradually arose, not always sharing a set of program objectives, but dominated by the obsession that the seemingly inevitable tendency of power to corrupt was at work in many who were a part of Federalist Administrations. ${ }^{80}$ As the key events of the 1790's unraveled-associated with, in succession, Hamilton's economic program, the neutrality debate, Jay's Treaty, and the crisis powers assumed by Federalists in 1798 and 1799-the Republican position became a cohesive ideology. ${ }^{81}$ By the end of the decade, even moderates such as Madison and Jefferson would be pushed into the more extreme camp of Republican partisans.

Republicans differed on numerous issues, and there were clear differences among the diverse groups that eventually would be associated with the figure of Thomas Jefferson. ${ }^{82}$ Uniting them ideologically were beliefs in inalienable personal rights, equality of participation in government, and above all, the principle that government must rest on consent. ${ }^{83}$ In practice, these principles translated into a decided preference for legislative authority over the other branches of government. By

tion to this government, that the representation consists of so few; too few to resist the influence of corruption, and the temptation to treachery, against which all governments ought to take precautions." Id. at 119. Although Paul Leicester Ford identified Cato as George Clinton, the Governor of New York, there continues to be dispute over the true author of Cato's letters. See 2 The CoMPLETE ANTI-Federalist, supra, at 102-03.

77 L. Banning, The Jefrersonian Persuasion: Evolution of a Party IdeOLOGY 116 (1978).

78 See C. Warren, The Making of the Constitution 733-34 \& 733 nn.1-2 (1928).

20 See L. BANNING, supra note 77, at 115-23.

so See id. at $117,126-29$.

81 See id. at 246-47.

${ }^{82}$ See Teton, The Story of Swift v. Tyson, 35 ILL. L. REv. 519, 521 (1941).

${ }^{83}$ See G. HASKINS, supra note 38 , at 65-66. 
stressing majority rule, many Republicans had taken a strange turn-quite a few in their ranks had helped construct a constitution inspired by a fear of excessive democracy and legislative domination. Behind the opposition lay an older view rooted in revolutionary ideology, that saw "[h]istory . . . as comprising a continuing struggle between liberty and tyranny, between liberty and power." 84 Attack focused on "the motives of the governors, not [on] the government itself," darkest of purposes." J8 Jefferson set the tone in correspondence to Washington, calling Hamilton's programs "adverse to liberty" and charging him with "calculat[ing] to undermine and demolish the republic." ${ }^{\text {8z }}$ Federalists generally were accused by Jefferson of attempting to "accomplish a monarchy peaceably, or force a resistance which with the aide of an army may end in monarchy."'88

For their part, Federalists were equally capable of seeing a conspiracy in every move of their rivals. Among other things, they labeled Republicans as "Jacobin[s]," "foreign intriguers," "ambitious popular Demagogues," "vicious and corrupt,"88 and associated them with "faction, intrigue, private ambition and desparate fortunes." changes were unlikely to produce a climate of rational discussion. Instead, America's first political parties formed themselves in an atmosphere of often intense personal animosities. Alexander Dallas reminded a jury in a 1799 sedition prosecution that "there are many gentlemen in this country who, from the occasion of the times, and the combination of circumstances . . . wear sword-canes. . . . [T] of party yet preserves a disposition to assassination . . . ."91 Jefferson lamented that "[m]en who have been intimate all their lives, cross the street to avoid meeting, and turn their heads another way lest they

84 Howe, supra note 65, at 160; see also G. STOURzH, AleXANDer Hamilton AND THE IDEA OF REPUBLICAN GOVERNMENT 124-25 (1970) (describing the themes of the literature of the period as the lust for power and corruption).

${ }^{85}$ L. BANNING, supra note 77, at 284.

${ }^{88}$ Howe, supra note 65, at 149.

${ }^{87}$ Letter from Thomas Jefferson to George Washington (Sept. 9, 1792), reprinted in 6 THe WRItINGs OF ThOMAS JefFerson 102 (P. Ford ed. 1895). The personal element was unmistakable: "I was duped . . . by the Secretary of State and made a tool for forwarding his schemes ...." Id.

${ }^{88}$ Letter from Thomas Jefferson to Charles Pickering (Oct. 29, 1799), reprinted in 9 The Works of Thomas Jefrerson 87 (P. Ford ed. 1905).

80 Letter from Stephen Higginson to Timothy Pickering (Aug. 29, 1795), reprinted in 1 AMERICAN Historical Association, ANNUAL REPORT 794 (1897).

${ }^{90}$ Letter from John Quincy Adams to Abigail Adams (May 16, 1795), reprinted in 1 The Writings of John Quincy Adams $340 \mathrm{n} .1$ (W. Ford ed. 1913).

91 Closing Argument, Trial of Duane, Reynolds, Moore and Cuming (Pa. Ct. Oyer \& Terminer 1799), reprinted in F. Wharton, State TrIals of ThE UNTTED States 376 (Philadelphia 1849). 
should be obliged to touch their hats." in saying that, by the middle of the 1790's, "American political life had reached the point where no genuine debate, no real dialogue was possible for there no longer existed the toleration of differences which debate requires. Instead there had developed an emotional and psychological climate in which stereotypes stood in the place of reality."9s

Aside from the earliest portion of the first Washington Administration, this was not a period in which constitutional principles were worked out through a process of reasoned articulation, persuasion, and accommodation. Nevertheless, this was the time when important issues of constitutional interpretation were initially exposed to the public consciousness. Some were to be resolved in a manner that would affect the development of our law for years to come. One of these was the question that we now refer to as federal common law.

\section{B. Politics and Constitutionalism}

It would require considerable space and take us far beyond the immediate purpose to detail all of the events of America's first decades as they related to the federal judiciary. This was a complicated period, and it resists easy generalization. In great part that is due to the intertwining of disputes over personalities, national policy, and constitutional interpretation. Distrust of the characters designing and conducting a national program would be related to assessments of its merit (and vice-versa), and those opposing-or supporting-a given policy might use any argument available. A constitution replete with openended phrases, deliberately reserving resolution of many matters to the political processes, was a particularly likely place to turn for authority, albeit an unlikely source of authoritative resolution. When questions reached the federal courts, they were often resolved by strongly partisan Federalist judges, whose opinions frequently incensed their Republican opponents. ${ }^{94}$

By carrying the discussion to the level of constitutionality, the stakes were raised along with the rhetorical heat. While the issues arose in the context of specific policy disputes, Americans ordinarily understood them in relation to their larger quest for societal definition. All sides spoke in terms of dedication to a "republican" form of society, a word that for many went beyond government to embrace the habits

92 Letter from Thomas Jefferson to Edward Rutledge (June 24, 1798), reprinted in 2 The Life of Thomas Jefferson 24 (G. Tucker ed. 1873).

93 Howe, supra note 65, at 150 .

of See R. ELIIS, supra note 71 , at 14 . 
and virtues of the people. Although the members of the new national polity were required by events to formulate theories to justify their political positions, the development of constitutional principles occurred amidst the intellectual torrents of the remarkable late eighteenth century. Gerald Stourzh has commented on the difficulties they faced:

The Founders' quest for the principles and the form of good government in America derives much of its poignancy from the fact that they were exposed to the conflicting claims of ancient and modern ways of thought and, even more baffling, to the ideas of those thinkers who made a last, desperate attempt to bridge the cleavage between antiquity and modernity. There was no agreement, and much groping in the dark among the Americans of the first generation of the Republic with respect to the substance of the liberty that was the object of their search. To the theoretical intricacies of the issue, there were added the problems of persuasion inherent in a democracy-the need for simplifying issues less than clear even to the most learned and brilliant. ${ }^{95}$

Hamilton's economic program, which was viewed by many as a danger to farm interests, raised simultaneously the basic issue of the federal government's (or any government's) involvement with economic planning. ${ }^{96}$ It came to be discussed as an issue of states' rights under the Constitution, although it also had significant ties to the rift between generally Federalist mercantile concerns and their agrarian opponents. ${ }^{97}$ More fundamentally, contrasting visions of the society were implicated. Jefferson cast the dispute as one between those like himself, who he said saw "no definite limits . . . to . . . progress," and others ("enemies of reform") inclined toward "steady adherence to the principles, practices, and institutions of our fathers."

If nothing else, Jefferson's stated ambition for the society is striking in its simplicity. His expression displays easy confidence in the ideological dichotomy it presents, as if a choice of societies had been presented, and the people were thereby given a short menu of possibilities. For Jefferson the spirit of republican virtue could persist only while the society remained "chiefly agricultural. . . . When [people] get piled upon one another in large cities, as in Europe, they will be-

9s G. STOURzH, supra note 84 , at 74 .

- See G. HASKINS, supra note 38, at 66-68.

or See id.

98 Letter from Thomas Jefferson to John Adams (June 15, 1813), reprinted in 2 The AdAMS-JefFerson LetTers 332 (L. Cappon ed. 1959). 
come corrupt as in Europe."99 Disagreeing, Hamilton and his supporters imagined the United States following Britain's model of a great industrial and trading society. ${ }^{100}$ Whether one or the other was more inclined toward some abstract notion of progress is rather beside the point. What is important is the difference between the two men in their evaluation of the potential for change in society and the role the national government should play. At a time when modern technology such as steam power had scarcely arrived in America, ${ }^{101}$ Hamilton was more astute in recognizing the inevitability of industrialization, and that "[c]ommerce and industry will still increase the disparity"102 in wealth among the population. He realized that these circumstances would create tensions, testing the national commitment to a free society; Hamilton warned the ratifying convention in New York:

As riches increase and accumulate in few hands; as luxury prevails in society; virtue will be in a greater degree considered as only a graceful appendage of wealth, and the tendency of things will be to depart from the republican standard. This is the real disposition of human nature: It is what, neither the honorable member nor myself can correct. $^{103}$

For Hamilton, the answer to the dangers presented by a society at once increasing its wealth, while moving away from a traditional economic base, was to actively shape its future. Government in the Hamiltonian scheme could play an integral part in helping the culture adjust to the strains of yet unimagined growth. Hamilton was not thinking in terms of a modern state with a vast and intricate interrela-

99 Letter from Thomas Jefferson to James Madison (Dec. 20, 1787), reprinted in 12 The Papers of Thomas Jefferson 442 (J. Boyd ed. 1955). Jefferson wrote:

Those who labour in the earth are the chosen people of God, if ever he had a chosen people, whose breasts he has made his peculiar deposit for substantial and genuine virtue. . . . Corruption of morals in the mass of cultivators is a phanomenon of which no age nor nation has furnished an example.

T. Jefferson, Notes on the State of Virginia, reprinted in Thomas JefferSON, Writings 290 (M. Peterson ed. 1984).

100 See G. STOURzH, supra note 84, at 7, 168.

101 See $1 \mathrm{H}$. Adams, History of the United States of America During THE AdMinistration OF Thomas JeFFerson 71 (1889).

102 A. Hamilton, Speech at the Federal Convention (June 26, 1787), reprinted in 1 The Records of the Federal Convention of 1787, at 432 (M. Farrand ed. 1911) (notes taken by Robert Yates).

103 A. Hamilton, Speech at the New York Ratifying Convention (June 21, 1788), reprinted in 5 The PaPers of Alexander Hamilton 42 (H. Syrett ed. 1962). For an analysis of these remarks, see G. STOURzH, supra note 84 , at 70-71. 
tionship of government and economy, but he did envision America becoming an empire that would rival the powers of Europe. ${ }^{104}$ Judged by the standards of his own day, he was decidedly more inclined toward state intervention in the economy than was Jefferson, and favored expansive readings of executive authority.

Again, however, attitudes depended to a large extent on whether the person actually had the responsibilities of office. Jefferson's first inaugural address reads as if it were a libertarian manifesto, advocating "a wise and frugal government, which shall restrain men from injuring one another, shall leave them otherwise free to regulate their own pursuits of industry and improvement, and shall not take from the mouth of labor the bread it has earned."105 We may not entirely agree with Hamilton's famous assessment of his rival: "Nor is it true that Jefferson is zealot enough to do anything in pursuance of his principles which will contravene his popularity, or his interest. He is as likely as any man I know to temporize-to calculate what will be likely to promote his own reputation and advantage . . ."108 But unquestionably the purity of Jeffersonian ideology suffered from the necessity of being implemented in a real world of political crisis and international intrigue. ${ }^{107}$ A longstanding obsession of Republicans was undue executive influence on the legislative branch. Yet Jefferson turned out to be a more active and forceful President than either Washington or Adams, even at the price of alienating some of his Republican followers. As a result of events like the Embargo of 1807, and the subsequent efforts to strengthen its enforcement, Americans found government intruding into their lives to an unprecedented degree. ${ }^{108}$ Although Jefferson never abandoned his commitment to the primacy of agriculture, his Adminis-

104 See G. STOURZH, supra note 84, at 192-201.

105 Inaugural Speech of President Jefferson (Mar. 4, 1801), reprinted in 1 american State Papers: Foreign Relations 57 (W. Lowrie \& M. Glarke eds. Washington, D.C. 1832).

${ }^{108}$ Letter from Alexander Hamilton to James A. Bayard (Jan. 16, 1801), reprinted in 25 The Papers of Alexander Hamilton 320 (H. Syrett ed. 1962). Hamilton added that Jefferson was "crafty \& persevering in his objects, that he [was] not scrupulous about the means of success, nor very mindful of truth, and he [was] a contemptible hypocrite." Id. at 319. Nevertheless, Hamilton acknowledged that there was "no fair reason to suppose him capable of being corrupted, which is a security that he will not go beyond certain limits." Id. at 320 .

107 Jefferson reflected after the experience of Presidency was past, "To lose our country by a scrupulous adherence to written law, would be to lose the law itself, with life, liberty, property and all those who are enjoying them with use; thus absurdly sacrificing the end to the means." Letter from Thomas Jefferson to John B. Colvin (Sept. 20, 1810), reprinted in Thomas JefFerson, Writings, supra note 99, at 1231.

${ }^{108}$ See L. Banning, supra note 77, at 280. 
tration came to encourage manufacturing, ${ }^{109}$ which Jefferson later characterized "as necessary to our independence as [it is] to our comfort."110

To a large extent Jeffersonians were the heirs of the radical Whig tradition that demanded that rulers be the mere instruments for executing the will of the people; at the same time they believed that the power of office necessarily corrupted the politician. ${ }^{111}$ When combined with Jefferson's conviction that virtue could be fostered only in an agrarian culture, the resulting philosophy stressed the necessity of a minimalist government as a prerequisite to liberty. This explains Jefferson's advocacy of Western expansion, which would assure-"with room enough for our descendants to the thousandth and thousandth generation"112 - a seemingly limitless territory for the cultivation of an egalitarian society in which the individual could be left alone by the state. It was not so much an appeal to some innate goodness of humans, as it was a belief that social conditions could raise insurmountable obstacles to virtue-or be instrumental to their attainment. ${ }^{113}$ A cornerstone of Jefferson's vision was the independence of the individual: "Dependence begets subservience and venality, suffocates the germ of virtue, and prepares fit tools for the designs of ambition."114 Use of credit, particularly when the government was involved, was to Jeffersonians a potent engine for personal destruction and a sure avenue to disproportionate wealth in the hands of "paper men"-an expression used frequently by Jefferson, who spent much of his life entangled in debts to distant creditors. ${ }^{115}$ Moreover, legislators would become holders of the public debt

108 See G. HAskins, supra note 38, at 68.

110 Letter from Thomas Jefferson to Benjamin Austin (Jan. 9, 1816), reprinted in 10 The Writings of Thomas Jefrerson 387 (P. Ford ed. 1899); see also A. Koch, The Philosophy of Thomas Jefrerson 172-74 (1943) (explaining that Jefferson's encouragement of manufacturing was motivated by his desire to ensure the use of domestic raw materials).

111 See G. STOURZH, supra note 84, at 184.

57.

112 Inaugural Speech of President Jefferson (Mar. 4, 1801), supra note 105, at

113 Gerald Stourzh writes: "The Jeffersonian conception of human nature predicated the possibility of human goodness on the equality not of legal rights only, but of material conditions and social status as well. Jeffersonian political theory had no remedy for a stratified society except the advice to do away with stratification." G. SrouRZH, supra note 84, at 181. An example of Jefferson's philosophy in practice would be his advocacy of public education, which had particular meaning to one whose home state's population was "uneducated to a degree that shocked their own native leaders." $1 \mathrm{H}$. ADAMS, supra note 101, at 137. 91.

114 T. Jefferson, Notes on the State of Virginia, supra note 99, at 290-

115 See D. Malone, JefFerson and the Ordeal of Liberty 176-79, 529-30 (1962). 
and directors of the national bank, leading inexorably to a corrupt affiliation with executive officers. ${ }^{116}$

Hamilton, on the other hand, was not unduly troubled by what he perceived as the tendency of "[m]en [to] pursue their interests," since "[a] wise legislator will gently divert the channel, and direct it, if possible, to the public good."117 Individuals were "neither . . . actuated by generosity nor reasons of state," and thus "to their interest alone we must appeal."118 A system of public credit, the establishment of a national bank, and the assumption of debts would play upon the selfinterest of "the monied interest of every State"119 and foster support of the government upon which their investments depended. ${ }^{120}$. Without harboring illusions about the character of "men of property," Hamilton believed they were nonetheless "enlightened about their own interest," ${ }^{21}$ and better candidates for leading the society:

Look through the rich and the poor of the community; the learned and the ignorant. Where does virtue predominate? The difference indeed consists, not in the quantity but kind of vices, which are incident to the various classes; and here the advantage of character belongs to the wealthy. Their vices are probably more favorable to the prosperity of the state, than those of the indigent; and partake less of moral depravity. ${ }^{122}$

Pronouncements of this sort did little to dampen Hamilton's reputation as an aristocrat who held the common person in high contempt-surely an irony in light of Hamilton's humble origins. He was prone to call democracy "our real disease, . . . the poison of which, by a subdivision, will only be the more concentrated in each part, and con-

11 See L. Banning, supra note 77 , at 168, 170-71.

117 A. Hamilton, Speech at the New York Ratifying Convention (June 25, 1788), supra note 103 , at 85 .

118 Continental Congress Report on a Letter from the Speaker of the Rhode Island Assembly (Dec. 16, 1782), reprinted in 3 The Papers of AlEXANDER HAMILTON, 216 (H. Styrett ed. 1962); see also G. STOURZH, supra note 84, at 188 (noting Hamilton's regard for the force of private interests).

118 Notes on the Advantages of a National Bank, reprinted in 8 THE PAPERS OF AleXander Hamilton 223 (H. Syrett ed. 1962).

120 See L. Banning, supra note 77, at 138-39.

121 Letter from Alexander Hamilton to Robert Morris (Apr. 30, 1781), reprinted in 2 The Papers of Alexander Hamilton 621 (H. Syrett ed. 1962); see also G. STOURzH, supra note 84, at 90-94 (explaining that Hamilton's desire to place "men of property" at the top of the political and social pyramid can be partly understood in terms of Hamilton's belief that these individuals were fairly rational).

122 Speech at the New York Ratifying Convention (June 21, 1788), supra note 103 , at 43. 
sequently the more virulent."123 Examined in light of the typical Federalist association of democracy with mob rule, Hamilton's view was not meant as a denial of any representative voice to the people. Rather it reflected a social conservatism that preferred a stable society to an open one, a state of affairs that was believed to be impossible to attain if the illiterate rabble were included directly in governance. Federalism in many parts of the United States-especially New England-was closely (although not invariably) associated with social class. ${ }^{124}$ The excesses of the French Revolution struck the reactionary Federalists as a grim reminder that the rude, gullible masses were easily susceptible to the lead of demagoguery.

However significant the Federalist contribution was in setting the country on course, maintaining the peace, and establishing the public credit, the party lost touch with the farmers and laborers that Jeffersonians artfully courted. ${ }^{125}$ Odd as it was for a slave-holding landed gentleman to become the champion of the ordinary person, the emergence of Republicanism itself was natural in a predominantly agricultural society whose people prided themselves in their presumed equality as vehemently as they opposed Federalist taxes.

These observations on the divisions in American society that resulted in the country's first great political parties may seem irrelevant to a study of an issue that is now almost exclusively the province of the legal community. Understanding the early relationship between the common law and the federal government involves an exercise in constitutional history, a field that professional historians have disparaged on

${ }^{123}$ Letter from Alexander Hamilton to Theodore Sedgwick (July 10, 1804), reprinted in 10 The Works of AleXANDER Hamilton 458 (H. Lodge ed. 1904).

${ }^{134}$ The reaction to Jefferson's election amongst those in the upper classes in New England illustrates the connection between class and politics. As the Beards noted, upon hearing of Jefferson's election: "Federalist ladies . . . shuddered with horror as they spoke of the 'atheist and leveler from Virginia.' Federalist politicians and conservative gentlemen stood aghast: all the grace and dignity of life, everything founded on knowledge and morals seemed destroyed in a flash." 1 C. BEARD \& M. BEARD, The Rise of American Givilization 380-81 (1927).

But the issue of class and politics was complex as was shown by the South. See J. Broussard, supra note 41, at 5-9. Professor Broussard notes that, in that region, "[o]pposed to the conservatives was a 'radical' or 'democratic' element, led often by persons of wealth but supported by small farmers in the Piedmont and mountains and occasionally by urban artisans and mechanics." Id. at 9 .

${ }^{123}$ Henry Adams's description of the politics in the early 1800's is still valid:

Federalism was already an old-fashioned thing; a subject of ridicule to people who had no faith in forms; a half-way house between the European past and the American future. The mass of Americans had become democratic in thought as well as act; not even another political revolution could undo what had been done.

2 H. ADAMS, supra note 101 , at 76 . 
occasion as "sterile and meaningless." "126 To avoid that criticism we must, at a minimum, approach the constitutional questions with an eye toward the manner in which the subject was treated by the first generation to live under the Constitution. As a process, constitutional inquiry assumed quite a different meaning in those days than it does now. Not only were constitutional arguments phrased in terms of a debate over the concept of republicanism, and presented by individuals who consciously identified themselves as revolutionaries; they were also frequently made for the sake of winning immediate political prizes.

For example, most of the important domestic issues that arose in the twenty years after 1794 were involved in one way or another with international affairs, and both parties exhibited a crude tendency to further "the popular image of the political struggle as a contest between 'French' and 'British' interests."127 And in the fashion of their times, each side characterized the events as an intricate interlocking web of conspiracy allegedly masterminded by their rivals. Federalists typically were accused of seeking national consolidation or, worse yet, a return to the British fold. Their constitutional arguments about national powers were portrayed, in the words of Albert Gallatin, as a move

to assimilate our government to a monarchy. Every measure seems to squint towards this darling object, and hence irredeemable debts, excise systems, national banks, loans, federal cities, reports for raising revenue by an officer unknown to the Constitution and dependent on the executive-hence the plan to excite the Western Insurrection to increase the national debt, to furnish a pretext for a standing army, and to supply arguments against the cause of republicanism. ${ }^{128}$

That Federalists engaged in similar reveries of free association by discerning French plotting behind various domestic events did little to cool the air. Federalists did not stop with strong language; they were capable of taking such measures as bringing treason charges, prosecuting for the common-law offenses of sedition and violating neutrality, and enacting the despised Alien and Sedition Acts. ${ }^{120}$

Once in power, however, most Republicans proved quite flexible when it came to previously sacrosanct constitutional positions. Jefferson

128 Cannadine, No Entrance (Book Review), N.Y. REv. Books, Dec. 20, 1984, at 64 (quoting Lawrence Stone).

${ }_{127}$ See L. BANNING, supra note 77, at 233.

128 A. Gallatin, An Examination of the Conduct of the Executive of the United States Towards The French Republic 41 (Philadelphia 1797), quoted in L. BANNING, supra note 77, at 242 (footnote omitted).

129 See Presser, supra note 55, at 94-95. 
himself was prepared to deal with the British in order to temper Napoleon's influence over Louisiana. When this proved unnecessary due to France's decision to sell Louisiana, Jefferson then agreed to the purchase, notwithstanding the fact that it violated "every canon of interpretation [of the Constitution] by the Virginia Republicans." Constitution did not specifically authorize what was then a massive expenditure. The doctrine of enumerated powers was at the core of the Republican creed; to concede authority beyond those powers specifically listed in the Constitution would allow for open-ended federal absorption of state sovereignty. ${ }^{131}$ Republican prognostication on the last point turned out to be right, even if the full implications for federal power would not be realized until more than a century later. In the meantime, the Louisiana Purchase threatened to alter radically the political composition of the nation and heightened the convictions of certain New England Federalists who urged secession from the Union. ${ }^{132}$ These Federalists defended their move on the ground that the Constitution was a compact of states, united by a federal government of limited powers-not terribly different than the theory underlying the Virginia and Kentucky Resolutions. Even less extreme Federalists in New England held to some version of "interposition," under which a state might insist in various ways on its own constitutional interpretation. ${ }^{133}$

1301 S. Morison \& H. Commager, The Growth of the American RepubLIC 1703-1805, at 392 (1942) (footnote omitted). Jefferson originally urged a constitutional amendment to obtain the purchase, explaining: "The general government has no powers but such as the constitution has given it; and it has not given it a power of holding foreign territory, \& still less of incorporating it into the Union. An amendment of the Constitution seems necessary for this." Letter from Thomas Jefferson to John Dickinson (Aug. 9, 1803), reprinted in 8 The Writings of ThOMAS JefFerson 262 (P. Ford ed. 1897). Shortly thereafter, he relented, telling a correspondent:

I confess, then, I think it important, in the present case, to set an example against broad construction, by appealing for new power to the people. If, however, our friends shall think differently, certainly I shall acquiesce with satisfaction; confiding, that the good sense of our country will correct the evil of construction when it shall produce ill effects.

Letter from Thomas Jefferson to Wilson Cary Nicholas (Sept. 7, 1803), reprinted in 4 The Writings of Thomas Jefrerson 507 (H. Washington ed. New York 1856). Putting the constitutional obstacle aside, Jefferson had good reason to move without the amendment: "Jefferson abandoned scruple . . . with reluctance and because there seemed some danger that the Emperor of France might change his mind about a bargain that could guarantee the nation's peace while promising indefinite postponement of the day when overcrowding and development might put an end to its capacity for freedom." L. BANNING, supra note 77, at 279.

131 See G. Haskins, supra note 38, at 66-68.

192 See J. Banner, To the Hartford Convention: The Federalists and the Origins of Party Politics in Massachusetts, 1789-1815, at 111-21 (1970) (discussing some Federalists' belief that the nation would, and should, divide at the Appalachians).

$13 s$ See id. at 118-19. 
It is one thing to point out inconsistencies in legal or philosophical stances, and quite another to claim that the asserted doctrines were conscious subterfuges for advancing a political program. Honest people have been known to change their minds in the face of experience and reasonable rebuttals. In any event, it would take a great deal more evidence than is presently available to show that the issue of common-law authority for federal courts was purely a creature of partisan politics. Nonetheless, in assessing the first decades of American constitutional development, a principled account of the Constitution's key provisions cannot be separated from the public affairs of the day. Those in and out of office were formulating a view of the Constitution as the realities of the federal experiment unfolded.

This last statement is not meant as merely another version of Chief Justice Marshall's oft-quoted expression, "we must never forget that it is a constitution we are expounding." cussion, nothing resembling our present nation was in place. At best the country remained a "loose federation of States,"135 whose future as a functioning unit was largely open to question. Particularly when Hudson was decided, a breakdown of the federal system was a distinct possibility. ${ }^{136}$ Constitutionalism in 1812 was not remotely similar to the process we now experience. No established national society existed that would lend stability to a course of constitutional construction. Dissatisfied players might well go home and remain there. And this was a real threat ${ }^{137}$ - the position of actual strength enjoyed by states is difficult for Americans of today to imagine.

These were not abstract disputes or arguments based on accumulated experience in a federal system. Preciously little from the past could be relied upon in resolving the chief dilemmas. English common law might afford clues to the meaning of some terms in the Constitution, ${ }^{138}$ but the absence of any close federal model was recognized even

134 McCulloch v. Maryland, 17 U.S. (4 Wheat.) 159, 200 (1819).

135 G. HASKINS, supra note 38 , at 15.

136 See L. BANNING, supra note 77, at 296-97. Dissenting Federalists were not the only ones who were equivocal in their support of the existing nation. Jefferson wrote in 1804 that it was "not very important" if "we remain in one confederacy, or form into Atlantic and Mississippi confederacies." Letter from Thomas Jefferson to Joseph Priestley (Jan. 29, 1804), reprinted in 8 The Writings of ThOMAS JeFrerSON 295 (P. Ford ed. 1897).

${ }_{137}$ See G. HASKINS, supra note 38, at 313. As Haskins explains, "In the early national period, arguments on behalf of the States could be made from a position of real strength; the new government was unsure of itself, and the States exercised a great deal more de facto power than they could after the 1820s." Id.

138 Many provisions of the Constitution employed common-law terms, and common-law principles were expected to provide guidance, as is indicated by various statements made during the ratification process. See, e.g., 3 The Debates IN THE Several 
at the Convention. ${ }^{138}$ Nor would models have been particularly useful. State sovereignty was a historical reality, not merely a philosophical theory. ${ }^{140}$ State governments were the primary political focus, and many recalled the established wisdom of the Revolution, that a republic could flourish only in a limited territory among people who shared common interests. ${ }^{141}$ States may have been perceived as "the accursed thing[s] which will prevent our being a nation," 142 but recognition of their sovereign power had been the price paid for the Union. ${ }^{143}$

Similarly, on the most important disputes over separation of powers, the infant nation had little guide save the lessons of revolutionaryera state constitutions, which generally were thought defective by the Framers in their allocation of dominant authority to the legislatures. Nothing in the colonial experience would have informed the Framers of the appropriate division of authority in a tripartite system distributing power among three independent functional units. ${ }^{144}$

With respect to the role of the federal judiciary, lawyers such as Attorney General Edmund Randolph were well versed in the ambiguities permeating article III. Randolph was also aware that the judici-

State Conventions on the Adoption of the Federal Constitution 530-31 (J. Elliot ed. 1836) (James Madison, Virginia Convention) (hereinafter cited as ELLIOT'S Debates]; 4 id. at 210 (Richard D. Spaight, North Carolina Convention). English common law has been turned to throughout our history as a source of constitutional meaning. See, e.g., Smith v. Alabama, 124 U.S. 465, 478-79 (1888) ("The interpretation of the Constitution of the United States is necessarily influenced by the fact that its provisions are framed in the language of the English common law, and are to be read in light of its history."); Minor v. Happersett, 88 U.S. (21 Wall.) 162, 167 (1874) (Since the Constitution is silent as to who shall be natural-born citizens, the meaning of the term must be found in the common law, "with the nomenclature of which the framers of the Constitution were familiar."). Moreover, in some places, the Framers deliberately avoided language that might invoke a common-law construction of terms. See, e.g., 2 ThE ReCordS OF THE FEDERAL Convention OF 1787, at 316 (M. Farrand ed. 1911) (statement of James Madison objecting to using the term "felony" because it was vaguely defined in the common law).

82 (1942).

199 See Coker, Commentary, in Federalism as a Democratic Process 79, 81-

140 See J. Goebel, supra note 59, at 723.

141 See G. WooD, supra note 68 , at 356-57.

142 Letter from General Henry Knox to Rufus King (July 15, 1787), reprinted in 1 The Life and CoRrespondence of Rufus King 228 (C. King ed. 1894) (stating that acceptance of the Constitution by the small states rested on the assurance that states' rights would be protected).

143 See W. CARPENTER, supra note 69, at 95-96.

144 See B. BAILYN, supra note 64 , at 70-73. The colonists had greatly admired the English model of separated powers, which envisioned the best State as one comprised of a mixture of three types-monarchy, aristocracy, and democracy-represented in their respective estates in society-royalty, nobility, and the commons. See id.; G. Woon, supra note 68, at 197-202. The American Constitution's system of separated powers, however, had "no place in the common law." Radin, The Doctrine of the Separation of Powers in Seventeenth Century Controversies, 86 U. PA. L. REv. 842, 844 (1938). 
ary's role was more than a question of power distribution among federal branches; it implicated states' rights, and the lack of jurisdictional clarity was a source of ire for state judges. ${ }^{145}$ The fit of common law in article III's framework and its relation to state law will be explored in Part Two of this essay. For our present purposes, the use of highly generalized language concerning the role of federal courts is what is important. ${ }^{148}$ Article III came about through a process of known compromises, ${ }^{147}$ still, few aspects of the debate (if any) on federal jurisdiction are documented. ${ }^{148}$ Probably the language chosen was deliberately vague, as many have suspected since, ${ }^{149}$ and to which Gouverneur Morris essentially confessed. ${ }^{150}$ An independent judiciary was undoubt-

145 Randolph told Washington by letter of August 5, 1792: "So crude is our judiciary system, so jealous are State judges of their authority, so ambiguous is the language of the constitution, that the most probable quarter, from which an alarming discontent may proceed, is the rivalship of these two orders of judges." Letter from Edmund Randolph to President Washington (Aug. 5, 1792), reprinted in 10 THE Writings of George Washington 513 (J. Sparks ed. Boston 1836). During the Virginia ratification debates, Randolph complained that article III should have "been more clearly expressed. What do we mean by the words arising under the Constitution? What do they relate to? I conceive this to be very ambiguous. . . . [T] arising will be carried so far that it will be made use of to aid and extend the federal jurisdiction." 3 Elliot's Debates, supra note 138, at 572.

146 One commentator has noted:

[W] must remember that there was a substantial amount of uncertainty in regard to the specific content of American law in the first half of the century of national existence. What is legal? What may the courts do? What are the limits of their powers and initiative? The vagueness of the judiciary article in the Constitution served to increase the frequency and heighten the seriousness with which these questions, natural to any new nation and new legal system, were asked.

L. Kerber, Federalists In Dissent 138 (1970).

147 See J. Schmidhauser, The Supreme Court as Final Arbiter in FedERAL-STATE Relations 1789-1957, at 7-8 (1958). According to Schmidhauser, the wording of article III was a result of a series of compromises between strong nationalists and states' rights advocates. One such compromise was the placing of lower federal court jurisdiction under congressional control. This was a compromise between states' rights interests who wanted to rely solely on state courts, and nationalists who wanted the lower federal judiciary defined in the Constitution. See id. at 13.

148 See C. WRIGHT, supra note 2 , at 2.

148 See, e.g., D. Sharpe, The Origins of American Admiralty and Maritime Law 268 (1969) (unpublished S.J.D. thesis, Harvard Law School); Forrester, The Nature of a "Federal Question," 16 Tul. L. REv. 362, 367 (1942).

${ }^{150}$ That instrument [the Constitution] was written by the fingers, which write this letter. Having rejected redundant and equivocal terms, I believe it to be as clear as our language would permit; excepting, nevertheless, a part of what relates to the judiciary. On that subject, conflicting opinions had been maintained with so much professional astuteness, that it became necessary to select phrases, which expressing my own notions would not alarm others, nor shock their selflove, and to the best of my recollection, this was the only part which passed without cavil.

Letter from Gouverneur Morris to Timothy Pickering (Dec. 22, 1814), reprinted in 3 
edly supported; the Framers knew that state courts had suffered in the Confederation period from legislative dominance. ${ }^{151}$ In terms of providing a system to implement such independence, however, they went into more uncharted waters. Judicial power had long been associated with the executive. ${ }^{\mathbf{1 8 2}}$ Explaining-much less forecasting-the eventual role of the judiciary in a constitutional order giving it co-equal status with the other branches of the government, while cabining the courts through vague jurisdictional grants subject to ultimate political control by Congress, was simply not possible. ${ }^{153}$

Given the ambiguities of the Constitution and the overall fragility of the political setting in the years under consideration, it was virtually inevitable that the federal judiciary would become entangled in the partisan exchange. During the 1790's a series of important disputes between the two camps came to the Supreme Court or before Justices on circuit. In addition to the important issue of whether the English common law was a part of federal law under article III, federal courts took on such questions as the constitutionality of the Alien and Sedition Acts, ${ }^{154}$ various controversies concerning American neutrality, ${ }^{155}$ and a number of matters directly implicating states' rights. ${ }^{156}$ From the Republican perspective, these disputes were virtually always decided wrongly, and the decisions thus revealed the tendencies of federal judges toward national consolidation, invasion of states' rights, and favoritism for the British at the expense of the French. ${ }^{167}$

Federalist judges were also directly implicated in Administration policies. Chief Justice Jay's negotiation of the treaty that bears his name is the best instance of this. From the very beginning of Jay's

The Records of the Federal Convention of 1787, at 420 (M. Farrand ed. 1911).

151 See F. Aumann, The Ghanging American Legal System: Some SeLected Phrases 161-65, 171-72 (1940); G. WoOd, supra note 68, at 155-56; Corwin, supra note 74, at 515-16.

152 See G. Woon, supra note 68, at 159-60 (discussing the coincidence of judicial and executive responsibilities and the review of colonial courts by the English Privy Council operating in the colonies).

${ }_{153}$ See Eliot, The Common Law of the Federal Courts, 36 AM. L. Rev. 498, 503 (1902) (noting that participants in the Constitutional Convention lacked a clear view of what the Constitution's effect would be with respect to judicial power). As Julius Goebel pointed out, "[t]he experience of most of the lawyers present [at the Convention] was not such as to stir an awareness of the import of what had been done." J. GoeBeL, supra note 59, at 244 .

154 See G. HASKINS, supra note 38, at 190.

156 See H. JoHNSoN, supra note 54, at 456-66.

${ }^{158}$ A leading example of this was Ghisholm v. Georgia, 2 U.S. (2 Dall.) 419 (1793). As Charles Warren related it, Chisholm "fell upon the country with a profound shock." 1 G. WARREN, supra note 38, at 96.

167 See G. Haskins, supra note 38, at 126, 159. 
mission to England, his role as emissary was widely attacked as violating the principle of separation of powers. Republican newspapers suggested that the President was making the judiciary an arm of the executive, and noted that Jay might have to construe as a judge the very treaty he negotiated. Others darkly reminded readers that without the Chief Justice's presence, impeachment charges against the President could not be tried. When the terms of the treaty were made known by leaks in the Republican Aurora, the reaction among the opposition was vehement, and the treaty was rebuked in the press and at popular meetings as a surrender of national honor to British insolence. Throughout the entire episode the character of Jay was thoroughly vilified, and Republicans repeatedly portrayed him as aristocratic and biased toward England. ${ }^{108}$

Republicans related almost every issue regarding the federal courts to some overall conspiracy. The Federalists' claim of a French threat was seen as a pretext to justify increased expenditures for the military during the Adams Administration, which in turn was linked to the personal aspirations of Hamilton. ${ }^{159}$ An increased defense establishment required massive sums, a permanent bureaucracy (with Federalist patronage), and a federal court system to augment collection efforts. Opposition could then be stifled by actions brought in federal court under the common law or the Sedition Act. ${ }^{\mathbf{1 6 0}}$

Many of these apprehensions were plausible. Under the Sedition Act, the mere "bad tendency" of an utterance was punishable ${ }^{161}$-including published criticism of the Administration or its laws. ${ }^{162}$ Prosecutions under the Act were aimed at leading Republican newspapers, causing a number to close. ${ }^{163}$ Membership in a Democratic Society was considered criminal because meetings were secret and the organizations lambasted the government. ${ }^{104}$ One man was prosecuted for simply claiming that the Federalists had created a standing army, ${ }^{185}$ and others were indicted for petitioning to repeal the Sedition Act. ${ }^{106}$ No deportations occurred under the Alien Acts, yet their threat,

168 See D. Stewart, The Opposition Press of the Federalist Period $177-$ 235 (1969).

169 See id. at 281-83.

180 See L. Banning, supra note 77, at 255-62, 264-67; Turner [now Preyer], Federalist Policy and the Judiciary Act of 1801, 22 WM. \& MARY Q. 3, 7-8 (1965). 161 See J. Smith, Freedom's FetTers: The Alien and Sedition Laws and AMERICAN Civil LiberTies 145 (1956).

162 See N. Schachner, The Founding Fathers 465-66 (1954).

163 See L. BANNING, supra note 77, at 256-57.

104 See N. SCHACHNER, supra note 162 , at 465.

165 See J. SMITH, supra note 161 , at 380 .

${ }^{186}$ See L. Banning, supra note 77, at 257. 
coupled with the seemingly real possibility of a declaration of war, caused numerous French immigrants to leave the country. ${ }^{\mathbf{1 6 7}}$

Further engendering hostility over the sedition actions was the conduct of federal judges in those cases and others with political overtones. Charges of overt prejudice abounded against judges said to be "[o]ften rude, frequently partisan or intemperate."168 Compounding the animosity was the use by federal judges of grand jury charges as a device to educate the public on matters they viewed as embracing community morality. Although the practice was not out of the ordinary for this period, Federalist jurists took the opportunity in charges to voice strong opinions on a variety of controversial subjects, and did not hesitate to excoriate partisan rivals from the bench. ${ }^{\mathbf{1 6 9}}$ Some openly participated in the campaigns of candidates for public office, ${ }^{170}$ and one sitting federal judge was elected to the Massachusetts Senate. ${ }^{171}$ John Sullivan, the "President" of New Hampshire, refused to resign that post after being appointed a federal district judge. ${ }^{172}$

Not all federal judges can fairly be accused of playing politics with their offices. ${ }^{173}$ A sizeable amount of the berating that they received reflected animosities toward courts in general. ${ }^{174}$ Other watchers of the

167 See id. at 255-56.

${ }^{168}$ G. Haskins, supra note 38, at 140; see also H. Ford, The RISE AND Growth of American Politics 112 (1898) (describing the actions of Federalist judges as "an amazing exhibition of headlong and reckless partisanship").

${ }^{169}$ See G. HASKINS, supra note 38, at 140,160, 221-22. See also Charge to the Grand Jury for the District of Virginia (Nov. 23, 1798) (Cushing, J.), reprinted in Federal Gazette (Baltimore), Dec. 6, 1798 (protesting "the clamors of faction, the unaccountable rage of PRETENDED PATRIOTS to subvert the government and general interest of this country, . . . slandering all REAL PATRIOTS with whom the constitution and the people have entrusted the management of their affairs . . . ."); Charge to the Grand Jury for the District of North Carolina (June 1, 1798) (Iredell, J.), reprinted in State Gazette of North Carolina (Edenton), July 4, 1798 (warning that "[w]e have a government formed and calculated to cherish, and with the best Intentions to preserve [peace and independence;] but in vain are all the efforts of the government if the people do not co-operate each in his several station in its support.").

$170 \mathrm{See}$ G. HASKINS, supra note 38, at 161.

171 See D. STEwART, supra note 158, at 454 . The Massachusetts Senate refused to seat the judge-senator, David Sewall, after Republicans denounced a man serving "two masters." Id.

172 See id. at 453-54. Sullivan made matters worse in his case by claiming that the New Hampshire Constitution was no longer in force after ratification of the federal Constitution. Republicans attacked Sullivan's conclusion that the state was no longer "sovereign and independent." Id.

${ }_{173}$ See Presser, supra note 55, at 38 (noting Judge Richard Peters's "unwillingness to embroil his district court in issues that would inflame popular opinion"). But Peters was only partially successful, as his role in United States v. Worrall, see infra text accompanying note 333, and the Bache libel cases, see infra text accompanying note 352 , demonstrate.

174 See F. AumanN, supra note 151, at 173-189; G. HASKINS, supra note 38, at 156-57. 
judiciary rightly reacted against what Edmund Randolph called the crudeness of the federal judiciary system. ${ }^{175}$ The practice of Supreme Court justices riding circuit, for example, produced interminable delays, cancellations, and expenses to suitors. ${ }^{176}$ Still, the antipathy was in large measure personal to the judges themselves and to the class they represented. A man like Jefferson, long an advocate of a vigorous and independent judiciary, ${ }^{177}$ would come, through observation of federal judges in office, to call them "the subtle corps of sappers and miners."178

\section{A Political History of the Early Debate over FEDERAL COMMON-LAW AUTHORITY}

Hostility to the invocation of common-law criminal jurisdiction by federal courts became increasingly acute as the decade of the 1790's unfolded. In the early years, there was little if any public notice of these prosecutions. ${ }^{178}$ In part, the lack of attention paid to these cases was probably a function of the scarcity of criminal cases that were even arguably within federal competence. ${ }^{180}$ Those that were, such as bribery, counterfeiting, and piracy, would not have implicated defendants who enjoyed public sympathy.

A review of grand jury charges by Justices on circuit reveals a minimum of overt effort, until the middle of 1793, to push for indictments without a statutory foundation. These charges were usually very general, and the Justices often spent most of their effort on indoctrinating the citizenry about the political theory of America's new Constitution. Cast in extravagant language, the charges were also reminders of the need for patriotic support of the national government. ${ }^{181}$

178 See Letter from Edmund Randolph to George Washington (Aug. 5, 1792), reprinted in 10 The WRITINGS OF GeORGE WASHINGTON 513 (J. Sparks ed. Boston 1836).

176 See G. Haskins, supra note 38, at 161.

177 See R. Ellis, supra note 71 , at 26.

178 Letter from Thomas Jefferson to Thomas Ritchie (Dec. 25, 1820), reprinted in 12 The Works of Thomas Jefrerson 177 (P. Ford ed. 1905).

178 See Presser, supra note 55, at 53-57.

180 During this period, federal judges often remarked on the scarcity of criminal business for the grand juries. See Charge to the Grand Jury for the District of Pennsylvania (Apr. 12, 1790) (Wilson, J.), reprinted in Pennsylvania Gazette (Philadelphia), Apr. 14, 1790; Charge to the Grand Jury for the District of Georgia (Apr. 26, 1792) (Iredell, J.), reprinted in Georgia Gazette (Savannah), May 3, 1792; Charge to the Grand Jury for the District of Massachusetts (Oct. 12, 1792) (Iredell, J.), reprinted in Columbian Centinel (Boston), Oct. 20, 1792.

182 See J. GoEBEL, supra note 59, at 620-21. Justice Jay's charges were usually relatively short, and were accompanied by stern reminders of patriotic duty:

It cannot be too strongly impressed on the minds of us all how greatly our 
Justice Jay's charges spoke sweepingly of "all offences committed against the law of the United States in this District, or on the high seas by persons now in this District." $182 \mathrm{He}$ instructed the jury to "[d]irect your attention also to the conduct of the national officers \& let not any corruptions, frauds, extortions or criminal negligences . . . pass unnoticed."183 In using such broad charges he apparently was including common-law offenses; at the time he gave this charge, there were few statutory crimes. Moreover, Jay voiced the expression that would soon become the centerpiece of nonstatutory prosecutions: "[T] he laws of nations make part of the laws of [the United States], and of every other civilized nation." 184 The jury responded with indictments for piracy, which was not then a statutory offense. ${ }^{185}$

In contrast with Jay's approach, Justices Wilson and Iredell would read or paraphrase the texts of criminal statutes to the juries. ${ }^{188}$ Nevertheless, Wilson did charge a grand jury on the law of treason prior to the passage of the first treason statute. ${ }^{187}$ Like Jay, Justice Wilson discussed the universal obligation imposed by the law of nations, including maritime law, and stated that much of the law of nations could not be altered by legislation or treaty because it was

individual prosperity depends on our national prosperity; and how greatly our national prosperity depends on a well organized, vigorous government, ruling by wise and equal laws, faithfully executed ... [ [and] irrefutably bearing down arbitrary power and licentiousness .....

Charge to the Grand Jury for the District of New York (Apr. 4, 1790), reprinted in New Hampshire Gazette (Portsmouth), June 3, 1790. Both Iredell and Wilson, on the other hand, were inclined toward lengthy and rather scholarly charges-with discussions of political theory and legal history, illustrated with numerous cites and quotations. See, e.g., Charge to the Grand Jury for the District of Virginia (May 23, 1791) (Wilson, J.) [original at Library of Congress, Washington, D.C.; copy on file with the University of Pennsylvania Law Review]; Charge to the Grand Jury for the District of Georgia (Oct. 17, 1791) (Iredell, J.), reprinted in Augusta Chronicle, Oct. 22, 1791; Charge to Grand Jury for the District of Maryland (May 7, 1793) (Iredell, J.), reprinted in 2 LIFE AND CoRRESPONDENCE OF JAMES IREDELI 386-94 (G. McRee ed. New York 1857).

${ }^{182}$ Charge to Grand Jury for the District of New York (Apr. 4, 1790), supra note 181.

183 Id.

184 Id.

188 The defendants were convicted, whipped and imprisoned. See J. GoEBEL, supra note 59, at 622-23. Justice Cushing and Judge James Duane sat with Jay. See id. at 622 .

${ }^{188}$ See, e.g., Charge to the Grand Jury for the District of Pennsylvania (Feb. 21, 1791) (Wilson, J.), reprinted in General Advertiser (Philadelphia), Mar. 15-17, 1791; Charge to the Grand Jury for the District of Georgia (Oct. 17, 1791), supra note 181.

${ }_{187}$ See Charge to the Grand Jury for the District of Pennsylvania (Apr. 20, 1790), supra note 180. Treason was codified in An Act for the Punishment of Certain Crimes against the United States on April 30, 1790, 1 Stat. 112, $\S 1$. 
grounded "in principles of natural law."188 Wilson further noted that to obtain the definitions of particular statutory crimes, the jurors should refer to the "pre-existing law . . the COMMON LAw" by which they could "ascertain, with precision, the true nature and qualities of such facts and transactions as shall become the objects of your consideration and research."189

Of the grand jury charges preserved from this period, only those of Justice Iredell appear expressly to exclude the use of nonstatutory prosecutions in federal courts. He pointedly told the grand jurors that "crimes committed against the United States . . . are defined, and the punishments prescribed, in certain Acts of Congress, passed in virtue of powers contained in the Constitution of the United States."180 In another charge he asserted that "it is peculiarly proper that the right of defining, and prescribing the punishment of such crimes should be vested in the Legislature . . . ."181 He even applied this "same observation ... to other violations of the Law of Nations as well as the particular instances of piracies and felonies committed on the high seas ...." "182

Justice Iredell would soon change his tune on this matter. ${ }^{193}$ Whatever reservations his colleagues on the federal bench may have felt on the question of federal common-law crimes, most would put them aside and endorse this type of prosecution. Not coincidentally, they would do so in cases that implicated hotly contested political issues. Debate over the common-law powers of the federal judiciary intensified after 1797 when the question came to be associated with the Sedition

188 Charge to Grand Jury for the District of Virginia (May 23, 1791), supra note 181 , at 16.

189 Id. at 13-14. Wilson gave the jurors numerous references to English authorities and cases to describe the elements of certain offenses. See also Charge to Grand Jury for District of Pennsylvania (Feb. 21, 1791), supra note 186 ("To the Common Law, then, recourse must be had for the definition and description of those crimes which have been mentioned ....."). In both charges, Wilson called the question of what law to refer to as "of immense importance and extent" and said that he could not "assign [his] reasons for [his] answer ... to the CoMmon LAw." Id., reprinted in General Advertiser (Philadelphia), March 16, 1791; Charge to Grand Jury for the District of Virginia (May 23, 1791), supra note 181, at 13.

190 Charge to the Grand Jury of the District of Massachusetts (Oct. 12, 1792), supra note 180 . note 181 .

101 Charge to Grand Jury for the District of Maryland (May 7, 1793), supra 102 Id.

193 See Charge to the Grand Jury of the District of South Carolina (May 12, 1794), reprinted in Gazette of the United States (Philadelphia), June 12-14, 1794 (explaining that although he once had doubts, he was now convinced that federal courts could exercise jurisdiction over common-law prosecutions); infra notes 248-50 and accompanying text. 
Act and the expansion of the federal court system under the short-lived 1801 Judiciary Act. But the origin of the controversy is earlier than these events. It first emerged as a rallying point for the nascent opposition when the Washington Administration used nonstatutory prosecutions to further foreign policy objectives.

\section{A. Beginning the Debate on Federal Common Law}

\section{The Neutrality Controversy}

During 1793, Washington was struggling to maintain America's neutrality in the ongoing European war, a goal shared by many leaders of the opposition. ${ }^{194}$ Americans were generally inclined to be sympathetic to France and hostile to Great Britain, sentiments manifested by activities ranging from street protests to active assistance for the French. Republican newspapers raged against American impotence in the face of British naval transgressions and the purported incitement by the British of Indian attacks on the frontier. ${ }^{195}$

Although Washington formally declared the country's noninvolvement on April 22, 1793, ${ }^{196}$ the French Minister to the United States-the outrageous Edmond C. ("Citizen") Genêt-actively enlisted Americans for the new Republic's cause. Among other schemes, Genêt commissioned privateers out of Charleston to cruise against vessels of France's rivals in the war, ${ }^{187}$ and he authorized the local French consul to hold proceedings against captured prizes. ${ }^{198}$ Reacting quickly, Britain's minister to the United States, George Hammond, wrote Thomas Jefferson (then Secretary of State) on May 8 to complain of the privateering. ${ }^{190}$ Although Hamilton advised Washington on May 15 that under the law of nations "[f]oreign recruiters are hanged immediately, and very justly," the Secretary of Treasury recommended

104 For accounts of the neutrality controversy and the Washington Administration's handling of relations with the European powers, see generally G. LYCAN, ALEXander Hamilton \& American Foreign Policy 206-25 (1970), and C. Thomas, supra note 32 , at $13-52$.

105 See D. STEWART, supra note 158 , at $143-58,177-87$.

108 For the text of the proclamation, see 1 American State Papers: Foreign RELATIONS, supra note 105 , at 140.

197 See Letter from Thomas Jefferson to Gouverneur Morris (Aug. 16, 1793), reprinted in 4 THE WRITINGS OF ThOMAS JeFFERSON 32-33 (H. Washington ed. New York 1856); G. Thomas, supra note 32, at 118-20.

188 See G. LyCAN, supra note 194, at 146; C. Thomas, supra note 32, at 206-07. Genêt also recruited Americans for military action against the Spanish in Louisiana and Florida. See G. LyCAN, supra note 194, at 146; G. Thomas, supra note 32, at 180.

190 See Letter from George Hammond to Thomas Jefferson (May 8, 1793), reprinted in Henfield's Case, 11 F. Cas. 1099, 1100 n.1 (C.C.D. Pa. 1793) (No. 6360). 
only that restitution of seized vessels be ordered and appropriate assurances be given to the British. ${ }^{200}$ The same day Jefferson sent two letters, one of which was a note to the United States Attorney in Philadelphia that was accompanied by reports of prizes being taken to that city. ${ }^{201}$ Referring to alleged participation of American citizens in the Genêt-instigated captures, Jefferson expressed "the desire of the government, that [the United States Attorney] would take such measures for apprehending and prosecuting them as shall be according to law."202 $\mathrm{He}$ also replied to Hammond that the United States

condemns in the highest degree the conduct of any of our citizens, who may personally engage in committing hostilities at sea against any of the nations, parties to the present war, and will exert all the means with which the laws and constitution have armed them to discover such as offend herein and bring them to condign punishment. ${ }^{203}$

Despite Jefferson's partiality for the French cause, his correspondence evidently was more than the mere fulfilling of the President's bidding. He wanted noninvolvement, yet he was uncomfortable with this position. Remaining neutral played directly into Hamilton's hand since his economic program depended upon vigorous trade with Britain, and implied a weakening of American support for France. ${ }^{204}$ Meanwhile, Federalists were making much of Genêt's plottings, and accused those criticizing the neutrality declaration of attacking the widely venerated figure of Washington. Actually many were attacking Washing-

200 See Letter from Alexander Hamilton to George Washington (May 15, 1793), reprinted in 4 The Works of Alexander Hamilton 410, 415 (H. Lodge ed. 1904); see also C. ThомAS, supra note 32, at 168-69.

${ }_{201}^{20}$ See Letter from Thomas Jefferson to William Rawle (May 15, 1793), reprinted in Henfield's Case, 11 F. Cas. 1099, 1101 n.1 (C.C.D. Pa. 1793) (No. 6360). 202 Id.

${ }^{203}$ Letter from Thomas Jefferson to George Hammond (May 15, 1793), reprinted in 6 THE WRITINGS OF ThOMAS JEFFERSON 252-53 (P. Ford ed. 1895). That day Jefferson sent Hammond's complaint to Jean de Ternant, Genêt's predecessor as French Minister to the United States; Jefferson cautioned the French ambassador: "[w]e will exert all the means with which the laws and constitution have armed us, to discover such offenders and bring them to condign punishment." Letter from Thomas Jefferson to Jean de Ternant (May 15, 1793), reprinted in 1 AMERICAN STATE PAPERS: Foreign Relations, supra note 105, at 147-48. He also warned against French consuls exercising prize jurisdiction, stating that this "could not be deemed an act of indifference." Id. at 147.

${ }_{204}$ See D. MALONE, supra note 115, at 69-73. Although Jefferson questioned the propriety of a "neutrality" declaration, which he thought was Congress's responsibility, he was nevertheless satisfied by the omission of the word "neutrality" from the proclamation. See id. at 69-70; see also G. LyCAN, supra note 194, at 164-67 (explaining Jefferson's fears that strong action against the French might lead to war with that nation). 
ton, in the form of demonstrations organized by Democratic Clubs that assembled in the open air of Philadelphia in 1793 and 1794 to denounce the Administration. Years later, when almost an octogenarian, John Adams reminisced (and exaggerated) to Jefferson that, according to friends in Philadelphia, only the outbreak of yellow fever in the capital "saved the United States from a fatal revolution."

Recognizing that Genêt "will sink the republican interest if they do not abandon him," the country from Americans privateering for France. He realized, however, that no statute in this country prohibited such activities. Genêt told him so directly in a letter of June 22, 1793: "Do not punish the brave individuals of your nation, who arrange themselves under our banner, knowing perfectly well, that no law of the United States gives to the Government the sad power of arresting their zeal by acts of rigor."207 Disregarding the French minister's request, Jefferson wrote James Monroe on July 14 that "the case is punishable, and that, if found otherwise, Congress ought to make it so . . ..2208 Explaining his position, Jefferson said to Monroe:

Treaties are law. By the treaty with England we are in a state of peace with her. He who breaks that peace, if within our jurisdiction, breaks the laws, and is punishable by them. And if he is punishable he ought to be punished, because no citizen should be free to commit his country to war. ${ }^{209}$

${ }^{205}$ Letter from John Adams to Thomas Jefferson (June 30, 1813), reprinted in 10 The Works of John Adams, Second President of the United States 47 (C. Adams ed. Boston 1856). For an account of the various street disturbances in Philadelphia, see generally G. LYCAN, supra note 194, at 173-74. Adams wrote that "Washington's house was surrounded by an innumerable multitude, from day to day, hurraing, demanding war against England, cursing Washington, and crying success to the French Patriots and virtuous republicans." CoRRespondence BETWEen HoN. John Adams and the Late WM. Cunningham, EsQ. 36 (E. Cunningham ed. Boston 1823), quoted in F. WHARTON, supra note 91 , at 5 n.*. Francis Wharton commented that, based on statements of William Rawle, "it appears that, so far as the 'innumerable multitude' is concerned, Mr. Adams' memory had failed him, yet there is no doubt that in the material point involved, the great party violence of the day, the statement was correct." See F. WHARTON, supra note 91, at 5 n.*; see also Howe, supra note 65, at 147-48 \& n.4 (noting a letter from John Adams to Thomas Jefferson in which Adams recalled that Washington smuggled arms into his home in response to the presence of mobs in the streets).

${ }^{208}$ Letter from Thomas Jefferson to James Madison (Aug. 3, 1793), reprinted in 7 The Works of Thomas Jefferson 464 (P. Ford ed. 1904); see also L. Banning, supra note 77 , at $217-18$.

${ }^{207}$ Letter from Edmond C. Genêt to Thomas Jefferson (June 22, 1793), reprinted in 1 American STATE PAPERS: Foreign Relations, supra note 105, at 156. ${ }^{203}$ Letter from Thomas Jefferson to James Monroe (July 14, 1793), reprinted in 4 The Writings of Thomas Jefferson 19 (H. Washington ed. New York 1856). $200 \mathrm{Id}$. at 18. 
This stance, he remarked, "coincided with all our private opinions; and the lawyers of this State [Pennsylvania], New York and Maryland, who were applied to, were unanimously of the same opinion."210

The Administration's posture on neutrality violations outlined in Jefferson's correspondence had already been enunciated by Chief Justice Jay, who had charged a federal grand jury in Richmond on May 22 that the United States was bound under the law of nations to honor its treaty commitments and that these required the country to remain uninvolved in the European conflict. ${ }^{211}$ It would be "criminal and wicked," he declared, for Americans to engage in hostilities: "[T]hey who commit, aid, or abet hostilities . . . offend against the laws of the United States, and ought to be punished . . . ."212 Included in the "laws" of the United States, he stressed, were treaties, the law of nations, the Constitution, and statutes of the United States. ${ }^{213}$ The thrust of Jay's remarks was that violators of neutrality harmed the nation itself, since " $[t]$ he peace, prosperity, and reputation of the United States, will always greatly depend on their fidelity to their engagements."214

The High Federalist Jay was certainly aware that the Republican press had been railing against the Neutrality Proclamation; the $\mathrm{Na}$ tional Gazette, only a week before, had accused the Administration of deserting the cause of liberty (and went on to urge an invasion of Canada). ${ }^{215}$ In part, Jay's grand jury charge appears to be an answer to these critics:

[I]n every nation individuals will always be found who, impelled by avarice or ambition, or by both, will not hesitate to

210 Id. at 19. Jefferson wrote Genêt on June 17, 1793:

For our citizens then to commit murders and depredations on the members of nations at peace with us, or to combine to do it, appeared to the Executive, and to those whom they consulted, as much against the laws of the land, as to murder or rob, or combine to murder or rob, its own citizens; and as much to require punishment, if done within their limits, where they have a territorial jurisdiction, or on the high seas, where they have a personal jurisdiction, that is to say, one which reaches their own citizens only ....

Letter from Thomas Jefferson to Edmond C. Genêt (June 17, 1793), reprinted in 1 AMERICAN STATE PAPERS: Foreign Relations, supra note 105, at 155.

211 Henfield's Case, 11 F. Cas. 1099, 1102-03 (C.C.D. Pa. 1793) (No. 6360)

(Grand Jury Charge of Jay, Gircuit Justice C.C.D. Va. 1793).

212 Id. at 1103-04.

213 See id. at 1100-01.

214 See id. at 1101. See also id. at 1103 ("If a sovereign who might keep his subjects within the rules of justice and peace, suffers them to injure a foreign nation, either in its body or its members, he does no less injury to that nation than if he injured them himself" (quoting a "celebrated writer on the law of nations")).

${ }^{215}$ See L. BANNING, supra note 77, at 212 (quoting National Gazette (Philadelphia), May 15, 1793). 
gratify those passions. at the expense of the blood and tears even of those who are free from blame. Such men are to be restrained only by fear of punishment. . . . It is not certain that the irritability of the belligerent powers, combined with some indiscretions on our part, will not involve us in war with some of them. Prudence directs us to look forward to such an event, and to endeavor not only to avert, but also to be prepared for it. Among our preparations, there can be none more important than union and harmony among ourselves. It is very desirable, that such an event do [sic] not find us divided into parties, and particularly into parties in favour of either foreign nation. Should this be the case, our situation would be dangerous as well as disgraceful. . . . [I]t is sincerely to be wished that our citizens will cheerfully and punctually do their duty to every other nation, but at the same time carefully avoid becoming partisans of any of them. There is not a history of any nation which does not record the mischiefs they experience from such parties, and they rarely present us with an instance of a nation being conquered and subjugated, without the detestable aid of its own degenerate or deluded citizens. [I]f such parties should arise among the people, they will find their way into every department of government, and carry distrust and discord with them-dark and dreary would then be the prospect before us, and we should in vain look for the speedy return of those happy days, when the government was peacefully, wisely and prosperously administered, under the care and auspices of a patriot, in whom the United States have by repeated unanimity in their suffrages, manifested a degree of confidence, no less reputable to their own wisdom and virtue than to his. 216

Some decoding is needed to catch the full spirit of these words. A reference to "parties" was aimed at those disparaging the "patriot" who had pronounced the neutrality. More basic was a concern for partisan division, which during the Revolution had been acknowledged repeatedly as a disease on the polity. ${ }^{217}$ Jay would have also reminded listeners that faction and dissension were widely perceived as prime flaws in the Confederation. ${ }^{218}$ Similarly, John Adams had warned that

216 Henfield's Case, 11 F. Cas. 1099, 1104-05 (C.C.D. Pa. 1793) (No. 6360).

217 See G. Wood, supra note 68, at 58-59.

218 As Gordon Wood explains: 
republics must always be wary of the inevitable tendency for parties to rise. ${ }^{219}$ In short, Jay triply accused Republicans-whose political strength in Congress was substantial by now-of disloyalty to the Revolution, the Constitution, and to Washington himself. And he insinuated that partisan division would find its "way into every department of government" - an undisguised reference to the rift between Hamilton on the one hand, and Jefferson and Madison on the other. ${ }^{220}$

\begin{abstract}
Many were now prepared to conclude that the great danger to republicanism was not magisterial tyranny or aristocratic dominance but "faction, dissension, and consequent subjection of the minority to the caprice and arbitrary decisions of the majority, who instead of consulting the interest of the whole community collectively, attend sometimes to partial and local advantages." Indeed, it was this factious majoritarianism, an anomalous and frightening conception for republican government, ... that was at the center of the Federalist perception of politics.
\end{abstract}

Id. at 502 (quoting Francis Corbin, Virginia Convention, 3 Eluror's Debates, supra note 138 , at 107$)$.

219 See $3 \mathrm{~J}$. Adams, A Defence of the Constitutions of Government of THE UNITEd States of AMERICA 432-33 (Philadelphia 1787). As a revolutionary, Adams had led his generation in espousing hopes for the "regenerative effects of republican government" on public virtue. See G. Woon, supra note 68 , at 570 . Though he then thought that education and spirited leadership could bring out the best in a republican people, by the late 1780's he was convinced "of the viciousness of his countrymen." Id. at 571. Adams spoke increasingly on the inherent division in society between the interests of the few and the many, a view that was steadily gaining adherents. See id. at 576. In the Defence, Adams wrote that "[t]he people, in all nations, are naturally divided into two sorts, the gentlemen and the simplemen," the distinction being based on whether the person had obtained a "liberal education," as opposed to knowledge of "trades or pursuits." $3 \mathrm{~J}$. ADAMS, supra, at 458 . Although education was not the exclusive province of the wealthy, "generally those who are rich, and descended from families in public life, will have the best education in arts and sciences, and therefore the gentlemen will ordinarily . . be the richer, and born of more noted families." Id. at 457-58. This division "produces resentments and jealousies, contempt, hatred, and fear . . . . [T]he common people endeavour to make friends, patrons, and protectors, among the gentlemen. This produces parties, divisions, tumults, and war . . ." Id. at 459.

Adams argued that social division was desirable in a properly constructed state, and he perceived the British system as such a state: "[W]hen the three natural orders in society, the high, the middle, and the low [monarchy, aristocracy, commons], are all represented in the government, and constitutionally placed to watch each other, and restrain each other mutually by the laws, it is then only that an emulation takes place for the public good, and divisions turn to the advantage of the nation." 2 J. ADAMS, supra, at 130; see also Gorwin, supra note 74, at 520 (observing that Adams' work is both an "exhortation to constitutional reform," and a warning of the dangers presented to the republic by the "rise of parties").

220 A more fundamentally divisive issue lay in Jay's commentary. Even Adams had acknowledged the inevitability of partisan politics-the question was what to do about it. Madison's solution, expressed at the Convention, was "to enlarge the sphere" of government and "thereby divide the community into so great a number of interests \& parties," such that no majority would "have a common interest separate from that of the whole," or "be apt to unite in the pursuit of it." 1 THE Records OF THE FEDERAL Convention of 1787, at 136 (M. Farrand ed. 1911) (June 6, 1787). While Madison would later view "states' rights" as the primary vehicle for achieving such pluralism, 
Meanwhile, preparations were underway for prosecutions in Philadelphia. In May, two Americans-Gideon Henfield and John Singletary-were arrested in that city's port while on board the Genêt-commissioned privateer, Citoyen Genet. They allegedly had served on the vessel (Henfield as prize master) while it brought a British prize into Philadelphia. Genet promptly protested that the "crime laid to their charge, the crime which my mind cannot conceive, and which my pen almost refuses to state, is the serving of France, and defending with her children the common and glorious cause of liberty."221 Jefferson responded to Genêt's plea for "the immediate releasement of the . . . officers" ${ }^{\prime 22}$ by coolly (and disingenuously) observing that the matter was in the hands "of the civil magistrate, over whose proceedings the Executive has no control." ${ }^{223}$ Only the day before, Jefferson had received Attorney General Edmund Randolph's formal opinion on the case:

Henfield is punishable, because treaties are the supreme law of the land; and by treaties with three of the Powers at war with France, it is stipulated, that there shall be a peace between their subjects and the citizens of the United States. . . . He is indictable at the common law, because his conduct comes within the description of disturbing the peace of the United States. ${ }^{224}$

Henfield's Case ${ }^{225}$ had evidently been slated as the Administration's

Federalists were inclined to see the solution in a strong, united federal government. As Jay had written in The Federalist, an efficient federal government, which attracted the "best men in the country" to participate in it, "will be more wise, systematical and judicious, than those of individual States, and consequently more satisfactory with respect to other nations, as well as more safe with respect to us." THE FEDERALIST No. 3 , at 15 (J. Cooke ed. 1961).

221 Letter from Edmond G. Genêt to Thomas Jefferson (June 1, 1793), reprinted

in 1 American State Papers: Foreign Relations, supra note 105, at 151.

${ }_{222}$ See Letter from Thomas Jefferson to Edmond C. Genêt (June 1, 1793), reprinted in 1 American State Papers: Foreign Relations, supra note 105, at 151. Jefferson subsequently wrote Genêt on June 5 relaying the President's request that the privateers "depart from the ports of the United States." Letter from Thomas Jefferson to Edmond C. Genêt (June 5, 1793), reprinted in 1 AMERICAN STATE PAPERS: ForEIGN RELATIONS, supra note 105, at 150. He advised "that it is the right of every nation to prohibit acts of sovereignty from being exercised by any other within its limits, and the duty of a neutral nation to prohibit such as would injure one of the warring Powers." Id.

${ }^{223}$ Letter from Thomas Jefferson to Edmond G. Genêt (June 1, 1793), reprinted in 1 American State Papers: Foreign Relations, supta note 105, at 150.

224 Opinion of the Attorney General (May 30, 1793) (submitted to the Secretary of State), reprinted in 1 AMERICAN State Papers: Foreign ReIATIONS, supra note 105 , at 152 .

22511 F. Cas. 1099 (G.C.D. Pa. 1793) (No. 6360). 
test case for neutrality prosecutions. ${ }^{226}$

On July 27, 1793, Justice Wilson called a special federal grand jury to investigate the matter. His charge was in form a learned, rather disconnected discourse, which among other things outlined the development of the common law throughout English history. Wilson also managed to answer some of these questions that Washington had put to the Court only nine days earlier, ${ }^{227}$ and which Chief Justice Jay would formally decline to answer on August $8 .{ }^{228}$

No offense was detailed as to its elements, but Wilson indicated that capturing British prizes was an infraction against the law of nations (which he said was based on natural law) and a violation of a citizen's duty to the United States. Under the former the United States was obligated not to lend the use of its ports to privateers, and this law of nations was binding on country and citizen alike. If the United States refused to prosecute violators, reprisals might be expected, war would be probable, and millions of people would be affected. No citizen could be allowed to place the country at this risk: "The constitution of the United States says no," inasmuch as the powers of war and granting letters of marque and reprisal were lodged exclusively in Congress. ${ }^{228}$

Five days after Wilson's charge, Henfield was indicted. The in-

${ }^{228}$ See C. Thomas, supra note 32 , at 173 . The Administration had planned in advance to use prosecutions for the implementation of the policies behind the Neutrality Proclamation. Jefferson wrote Attorney General Randolph on May 8, 1793, two weeks after the Proclamation was issued:

The Judges having notice of the proclamation, will perceive that the occurrence of a foreign war has brought into activity the laws of neutrality, as a part of the law of the land. This new branch of the law they will know needs explanation to the grand juries more than any other. They will study $\&$ define the subjects to them $\&$ to the public. . . . It will be easy to suggest this matter to the attention of the judges, \& that alone puts the whole machine into motion.

Letter from Thomas Jefferson to Edmund Randolph (May 8, 1793), reprinted in 7 The Works of Thomas JefFerson 318 (P. Ford ed. 1904). Julius Goebel commented that this passage gives "reason to believe that the content of [Jay's] charge had been the result of some conferring with members of the executive department." J. GoEBEL, supra note 59, at 624 .

227 See Henfield, 11 F. Cas. at 1105-09; see also J. GoEbel, supra note 59, at 626 ("Iredell's general charge of June 2,1794, was even more responsive" to the questions on neutrality submitted to the Court.)

${ }^{228}$ See J. GoEBEL, supra note 59, at 626 n.68 (explaining that Jay's refusal was "grounded in the separation of powers and in the impropriety of extrajudicial decision of the questions proferred"); Letter from Chief Justice John Jay and Associate Justices to George Washington, Aug. 8, 1793, reprinted in 3 The CoRREsPondence AND Public Papers of John Jay 488-89 (H. Johnston ed. 1891).

${ }^{220}$ See Henfield, 11 F. Cas. at 1108 (Grand Jury Charge of Wilson, Circuit Justice). 
dictment appears to have been drawn by the United States Attorney, William Rawle, the Attorney General, Edmund Randolph, and the Secretary of Treasury, Alexander Hamilton. ${ }^{230}$ It asserted that Henfield had violated various treaties that the United States had with France's European enemies; he was charged several times with infringing the law of nations, and each count ended by claiming that his deeds were in violation of the laws and Constitution of the United States, as well as "against the peace and dignity of the said United States."231

Henfield was tried before Justices Wilson and Iredell, and District Judge Richard Peters. After listening to the defense (financed by Genêt ${ }^{\mathbf{2 s 2}}$ presented by three prominent lawyers associated with Republican causes-Peter Du Ponceau, Jared Ingersoll, and Jonathan Dickinson Sergeant ${ }^{238}$ - the judges instructed the jury of their unanimous opinion that the defendant's "acts of hostility ... . [were] an offence against this country, and punishable by its laws." defense's contention that there was no law defining the crime, Wilson gave the court's conclusion to the jury:

It has been asked by his counsel, in their address to you, against what law has he offended? The answer is, against many and binding laws. As a citizen of the United States, he was bound to act no part which could injure the nation; he was bound to keep the peace in regard to all nations with whom we are at peace. This is the law of nations; not an ex post facto law, but a law that was in existence long before Gideon Henfield existed. There are, also, positive laws, existing previous to the offence committed, and expressly declared to be part of the supreme law of the land. The constitution of the United States has declared that all treaties made, or to be made, under the authority of the United States, shall be part of the supreme law of the land. I will state to you, gentlemen, so much of the several treaties in force between America and any of the powers at war with France, as applies to the present case. ${ }^{235}$

Summarizing the various treaties involved, the court stressed that these

230 A draft of the indictment appears in the handwriting of Randolph, with marginal corrections "apparently" by Hamilton. See Henfield, 11 F. Cas. at 1115 n.3.

${ }^{281}$ Id. at 1109-15.

282 See G. Thomas, supra note 32, at 171.

2ss See D. MALONE, supra note 115 , at 120 . At the time, Ingersoll was Attorney General of Pennsylvania.

2st Henfield, 11 F. Cas. at 1120.

285 Id. 
"were in the most public, the most notorious existence, before the act for which the prisoner is indicted was committed."238

Henfield was acquitted by the jury, much to the chagrin of the Administration, which worried that the verdict would be taken by the English as a sign that private Americans could aid the French with impunity. Genêt indeed proclaimed exactly that, while he busily continued to recruit Americans to the French cause-even to the point of taking out advertisements in newspapers. ${ }^{237}$ On August 16, 1793, Jefferson wrote Gouverneur Morris, the American Minister to England, in part to rebut the claims being made by Genêt that "no law of the United States authorizes their government to restrain either its own citizens or the foreigners inhabiting its territory, from warring against the enemies of France."238 $\mathrm{He}$ enclosed copies of Jay's and Wilson's grand jury charges and gave an account of Randolph's "official opinion" on the case, all of which established that these actions were "punishable by law."239 With respect to the acquittal, Jefferson ventured that Henfield was absolved on the facts-arguably the defendant had "been ignorant of the unlawfulness of his undertaking," and in any event he was a man who "had rendered meritorious services during the late war" and now showed "real contrition" for his actions. ${ }^{240}$

${ }^{258}$ Id. The conduct of the Henfield judges in declaring the defendant guilty was not an isolated occurrence. In one of the Whiskey Rebellion trials, for example, Justice Paterson summarized the evidence against one John Mitchell for the crime of high treason; he then concluded: "Upon the whole, ... the prisoner must be pronounced guilty. The consequences are not to weigh with the jury: it is their province to do justice; the attribute of mercy is placed by our constitution in other hands." United States v. Mitchell, 26 F. Cas. 1277, 1282 (C.C.D. Pa. 1795) (No. 15,788). Mitchell was then convicted, but subsequently pardoned. See $i d$.

237 See G. LYCAN, supra note 194, at 163-64.

${ }^{238}$ Letter from Thomas Jefferson to Gouverneur Morris, reprinted in 4 THE Writings of Thomas JefFerson 38 (H. Washington ed. New York 1856).

230 See id.

${ }^{240}$ See $i d$. There is some plausibility to Jefferson's account as Henfield apparently testified that his motive for service on the privateer was to gain passage to Philadelphia-where the prize was brought. When he went before the magistrate in Philadelphia, Henfield declared his lack of knowledge of Washington's proclamation and protested that he would not have served if he knew it was contrary to the President's wishes; he professed to being "an American, that as such he would die." See Henfield, $11 \mathrm{~F}$. Cas. at 1116. On the other hand, there is evidence that the jury may have been swayed by the possibility that Henfield had relinquished his American citizenship prior to the capture. See id. at 1122 . A month after his first appearance before the magistrate, Henfield "declared he had espoused the cause of France, that he now considered himself as a Frenchman, and meant to move his family within their dominions." Id. at 1116. Throughout the trial, Genêt referred to Henfield and John Singletary, who was captured with him, as "officers in the service of the Republic of France," $i d$. at 1123 n.7, and Henfield promptly re-enlisted for privateering duty after his acquittal. See G. LYCAN, supra note 194 , at 163 . Henfield was then captured by the British. See Henfield, 11 F. Cas. at 1123 n.7.

It is also possible that the jurors were coerced into making their decision, see $1 \mathrm{C}$. 
Whatever the actual explanation for the jury's decision, the Republican press greeted the acquittal with what John Marshall later called "extravagant marks of joy and exultation."241 Federalists were accused of "introducing motives of policy" into "the decisions of our courts," and as Marshall recorded, the Republican newspapers "universally asked, "what law had been offended, and under what statute was the indictment supported?" "242 This was distinctly a party reaction. Francis Wharton's account of the case notes that, although the case "was not reviewed by the court in banc, ... the ruling of the court at the trial . . . received the assent ... of all the judges of the Supreme Court but one. Chief Justice Jay . . . announce[d] the jurisdiction in advance with great solemnity, in a charge which exhibit[ed] grave deliberation."24s Nevertheless, Washington's address to Congress the following December contained a plea to extend federal jurisdiction over Americans acting in violation of the country's neutrality. ${ }^{\mathbf{2 4 4}}$ By June of 1794 Congress had complied with Washington's request, ${ }^{245}$

WARREN, supra note 38, at 144 n.1; Presser, supra note 55, at 55; alternatively, the jurors may have been influenced by French sympathizers who were on the jury, see id. at 55-56.

${ }^{241}$ Henfield, 11 F. Cas. at 1123 n.7 (quoting J. Marshall, Life of WashingTON 273-74 (Philadelphia 1807)).

212 Id. Marshall thought that prosecutions of this sort were constitutional. See infra appendix.

${ }^{243}$ F. Wharton, supra note 91 , at 87 . n. , reprinted in Henfield, $11 \mathrm{~F}$. Cas. at 1122 n.6. Wharton did not document his conclusion about the Justices' near unanimous opinion-beyond the obvious that Jay, Iredell and Wilson were in favor of jurisdiction. Nor was Wharton alive at the time to have received direct accounts of the case. We do know, however, that Justice William Cushing had already participated with Jay in a trial for piracy, in which the charges were justified in part under the law of nations. See supra note 185. As for Justice William Paterson, there is an undated entry in a section of his papers entitled "Opinions on the Bench" that reads:

Suppose the U[nited] States to be at peace with G[reat] Britain and 'France, while they are at war with each other; and that, during such a state of things, a citizen of the U[nited] S[tates] should enlist in the army of G[reat] Britain and faight ag[ains]t France. This is an offence-How? By the law of nations, or, in other words, by the common law, which comprehends the law of nations. It is too an offence arising under the const[itutio]n, as distinct from an offence arising under the law of the U[nited] States; because we have no stat[ute] on the subject. How is it to be proceeded ag[ains]t and punished? By indict[men]t at com[mon] law, which, on conviction, annexes a sanction or penalty of a fine and imprisonment.

W. Paterson, William Paterson Papers 1783-1804, at 563 [original in New York Public Library; copy on file with the University of Pennsylvania Law Review]. This must have been written prior to June 1794 when the neutrality statute was passed, see infra note 245 .

24 See 2 P. Smith, John Adams 842-43 (1963).

245 See Act of June 5, 1794, ch. 50, 1 Stat. 381, repealed by Act of April 20, 1818, ch. 88,3 Stat. 450 . 
and prosecutions soon followed. ${ }^{\mathbf{2 4 6}}$

\section{The Common Law and the Nature of Judicial Power}

Henfield represents an important dividing point in the history of the federal common law. Cases had previously been entertained by federal judges without statutory basis, but Henfield was the first that required extensive justification. Furthermore, the prosecution drew the approval of a wide range of important political figures, from Hamilton and Jay to Jefferson and Randolph. For some supporters, the neutrality cases would require a reformulation of previously held beliefs on federal judicial power. A good example is Justice Iredell, who had been insisting to grand juries as late as May 1793 that federal criminal indictments be supported by statute. ${ }^{\mathbf{2 4 7}}$ One year later, Iredell informed a grand jury in Columbia, South Garolina, that citizens were indictable under the law of nations for acting in violation of the Neutrality Proclamation. After confessing to having doubted at one time the propriety of such actions, he advised that in light of the "very able arguments in an important case," prosecutions are "maintainable for such offences..., though no act of Congress expressly prescribes it ...."248

Iredell was undoubtedly referring to Henfield. The events surrounding that case had exposed for him "the ridiculous and contempti-

${ }^{216}$ See, e.g., United States v. Guinet, 26 F. Cas. 53 (C.C.D. Pa. 1795) (No. 15,270). In Guinet two individuals were found guilty of "fitting out and arming" a vessel for use against the British. Justice Paterson's jury charge interpreted the evidence in a manner heavily favorable to the prosecution. See id. at 57-58. In its argument, the defense alluded to a Boston grand jury's refusal to indict persons for similar acts in service to France; it is not clear from the report whether this refusal to indict occurred before Congress authorized neutrality violation prosecutions. See id. at 55 .

${ }^{247}$ See supra text accompanying notes 190-92.

248 Charge to Grand Jury for the District of South Carolina (May 12, 1794), reprinted in Gazette of the United States (Philadelphia), June 14, 1794. Iredell continued:

Consequently, if there be a principle in the Common Law (as there unquestionably is) which subjects a man to a public prosecution for a contempt of his duty to the community, this must be understood as one of those cases comprehended within that class of public offences, and may be proceeded against accordingly.

Id. Iredell repeated this position in a 1796 charge. See Charge to the Grand Jury for the District of Pennsylvania (Apr. 12,1796), reprinted in Claypoole's American Daily Advertiser (Philadelphia), Apr. 18, 1796. But he preferred legislatively declared crimes; he told a grand jury in 1797 that the neutrality act had "substitute[d] a precise and positive direction as to punishments" for the common-law offence, which was "too vague and indefinite to be regarded with equal confidence and respect." Charge to the Grand Jury for the District of Pennsylvania (Apr. 11, 1797), reprinted in Philadelphia Gazette, Apr. 17, 1797. 
ble spectacle"248 of citizens betraying the neutrality policy of the country. Iredell described the issue as simply a question of "what reason dictates, that attribute which the Almighty has bestowed upon all mankind for the ultimate guide and director of their conduct."250 This expression, however, was a perfectly ordinary way for judges in the middle 1790's to characterize their activity. Iredell and the other judges associated with Henfield were involved in a situation that required them to formulate and defend constitutional principles about judicial power while carrying out an immediate political task.

The subsequent history of federal common-law jurisdiction before Hudson is an interplay of political motivations and theoretical constitutional arguments. To appreciate the essential forces that would shape the controversies in the years to come, it is necessary to pause momentarily from the chronological account to discuss how the issue of the common law was related to the subject of federal judicial power in Henfield.

Wilson's grand jury charge in Henfield reveals a theory of law that would prove to be remarkably resilient in American legal thought. The case technically did not involve a "common-law" crime-if that expression is taken to mean the nonstatutory law of Great Britain. ${ }^{251}$ Wilson's charge should be read as enunciating a theory of common-law adjudication, a means by which judges-who were usually unguided by statutes-would arrive at a conclusion. He saw the common law as a "social system of jurisprudence," which "receives other laws and systems into a friendly correspondence." 252 After reciting this passage, Wilson turned to the law of nations, which he labeled "[t]he law of nature when applied to states or political societies."253 Sandwiched in between these two statements is a telling observation on the sources of law and their proper choice:

Does a contract bear a peculiar reference to the local laws of any particular foreign country? By the local laws of that foreign country the common law will direct the contract to be

249 See Charge to the Grand Jury of the District of South Carolina (May 12, 1794), reprinted in Gazette of the United States (Philadelphia), June 12, 1794.

$280 \mathrm{Id}$.

261 See J. GoEBel, supra note 59, at 626-27; Anonymous, The Extent to Which the Common Law is Applied in Determining What Constitutes a Crime, and the Nature and Degree of Punishment Consequent Thereupon (pt. 2), 6 AM. L. REG. 129, 131-32 (1867). The prosecution in Henfield did contend, however, that the defendant was indictable at common law. See infra note 433.

${ }^{262}$ Henfield, 11 F. Cas. at 1107 (citing Calvin's Case, 77 Eng. Rep. 377, 7 Coke 1 (1608)).

25s Id. 
interpreted and adjusted. Does a mercantile question occur? She determines it by the law of merchants. Does a question arise before her, which properly ought to be resolved by the law of nations? By that law she will decide the question. For that law in its full extent is adopted by her. The infractions of that law form a part of her code of criminal jurisprudence. $^{254}$

Most of us would find this a strange appendage to a grand jury charge. That Wilson apparently saw relevance to its inclusion reflects some of the differences between his view of the law and our more modern assumptions. His instructions basically followed Blackstone's system of division for the English common law. According to Blackstone, each part of the common law was a form of established custom. Blackstone first identified "general customs, or the common law properly so called," as the "universal rule of the whole kingdom," which formed the foundation of the jurisprudence for "the king's ordinary courts of justice"-Chancery, King's Bench, Common Pleas, and the Exchequer. ${ }^{255}$ Second, "particular customs" were those used by "particular counties, cities, towns, manors, and lordships" in departure from general customs. ${ }^{28 B}$ Finally, there were "those peculiar laws, which by custom are adopted and used only in certain peculiar courts . . . [as with] the civil and canon laws."257 This separation of laws into those of general applicability and others that relate to particular local circumstances would pervade American legal thought for years, as is illustrated by Swift $v$. Tyson' ${ }^{258}$ use of a similar demarcation. ${ }^{258}$

To describe the common law as containing a significant branch of general law, derived from principles of natural justice, however, was not to claim the existence of a uniformly recognized body of legal principles. Julius Goebel has pointed out that Americans hardly "were be-

284 Id. (citing 4 W. Blackstone, Commentaries 67 (7th ed. Oxford 1775).

${ }^{253}$ See 1 W. Blackstone, Commentaries, supra note 254, at 63, 67, 68; $\mathbf{R}$. Bridwell \& R. Whitten, The Constitution and the Common law: The Decline of the Doctrines of Separation of Powers and Federalism 16 (1977). ${ }^{258}$ See $1 \mathrm{~W}$. Blackstone, supra note 255 , at 74.

257 Id. at 79.

25841 U.S. (16 Pet.) 1 (1842).

200 This will be discussed in Part Two. See also T. Freyer, Harmony \& DisSONANCE: The SwifT \& ERIE Gases In American Federalism $37-38$ (1981); Heckman, The Relationship in Swift v. Tyson to the Status of Commercial Law in the Nineteenth Century and the Federal System, 17 AM. J. LEGAL HIST. 246, 247-48 (1973); Hollingsworth, Comments on Charles A. Heckman's Paper "The Relationship of Swift v. Tyson to the Status of Commercial Law in the Nineteenth Century and the Federal System," and Donald Roper's Paper, "James Kent and the Emergence of New York's Libel Law," 17 AM. J. Legal Hist. 256, 258 (1973). 
guiled into believing that they lived by a hierarchy of customs that was law the world over."260 For one thing, the various states differed greatly in the degree and manner to which they adopted the English common law. ${ }^{261}$ Furthermore, hostility to English institutions was sufficiently intense to make it highly unpopular in many areas to contend that English law had been incorporated as a body of recognizable rules. ${ }^{262}$

Notwithstanding these sentiments, Americans of this time did not generally reject that part of their English heritage of law that, in Bernard Bailyn's words, consisted of a belief in "God-given, natural, inalienable rights, distilled from reason and justice," and was expressed partially "in the common law of England."263 Discovering the principles of this natural law required an investigation of inherited custom. James Kent in his Commentaries would quote Matthew Hale as saying that natural law was " "not the product of the wisdom of some one man, or society of men, in any one age; but of the wisdom, counsel, experience, and observation of many ages of wise and observing men." "264 Cases were merely the best evidence of the principles of the common law, ${ }^{268}$ the same point made years later in Swift. ${ }^{268}$

Morton Horwitz has demonstrated that this attitude toward law

${ }^{260}$ Goebel, Ex Parte Clio, 54 Colum. L. Rev. 450, 457 (1954).

261 Justice Jay said in a 1790 grand jury charge that at the time the nation was formed, "[o]ur jurisprudence varied in almost every State, and was accommodated to local, not general convenience-to partial, not national policy." Charge to the Grand Jury for the District of New York (Apr. 4, 1790), reprinted in New Hampshire Gazette (Portsmouth), June 3, 1790.

282 See L. Friedman, A History of American Law 94 (1973); see also A. Howard, The Road From Runnymede: Magna Carta and ConstitutionalISM IN AMERICA 260 (1968) (discussing various American attitudes towards English common law); Pound, The Place of Judge Story in the Making of American Law, 48 AM. L. Rev. 676, 681-82 (1914) (examining popular hostility to English law); Waterman, Thomas Jefferson and Blackstone's Commentaries, in EsSAYS IN THE HISTORY OF EARLY AMERICAN LAW 451, 453 n.12 (D. Flaherty ed. 1969) (describing the hostility felt with regard to English law). As will be explained in Part Two, however, in practice most American courts in this period followed English law rather closely.

263 B. BAILYN, supra note 64 , at 77 .

294 J. Kent, Commentaries on AMERican Law 439-40 (New York 1826).

205 See, e.g., Hunter v. Blodget, 2 Yeates 480, 481-82 (Pa. 1799) (recognizing that opinions of English judges since the Revolution are received as evidence of the law, although not authoritative of themselves). This "best evidence" principle has been recognized by many commentators. See, e.g., $1 \mathrm{~J}$. KENT, supra note 264, at $473 ; 1 \mathrm{Z}$. SWIFT, A SYSTEM of THE LAWS OF THE STATE OF ConNECTICUT 40-41 (Windham, Conn. 1795). See also Kempin, Precedent and Stare Decisis: The Critical Years, 1800 to 1850, 3 AM. J. LEGAL HIsT. 28, 30-31 (1959) (discussing the "best evidence" principle as the classical English view); Pope, The English Common Law in the United States, 24 HARv. L. REv. 6, 7 (1910) (examining the two views of common law-judge-made and judge-discovered).

${ }_{266}$ See 41 U.S. (16 Pet.) 1, 18 (1842) ("[D]ecisions of courts . . . . are, at most, only evidence of what the laws are, and not, of themselves laws."). 
was under attack in Wilson's time and would eventually be replaced by a view of judges as instrumental decisionmakers who were making rules, not discovering them. ${ }^{28 z}$ Still, the older conception of objectively discernible principles underlying judicial decisions persisted in many circles throughout the next century ${ }^{288}$ It did so despite its being at odds with the fundamental ideological shift occasioned by the Revolution. The Revolution had not merely been a series of battles culminating in a peace treaty; rather, it was more an alteration of consciousness. John Adams wrote that "the real American revolution [was the] radical change in the principles, opinions, sentiments, and affections of the people . . .."269 Ideologically, this was a new world: gone was the sovereignty of Kings and in its stead was placed the sovereignty of popular consent. ${ }^{270}$ Applied to the judiciary, this new attitude required a complete reformulation of the foundation for judicial authority. ${ }^{271}$ The trial court's charge in Henfield illustrates a preoccupation with justifying the court's power-specifically the authority of judges to declare criminal offenses.

"Judges have no power to frame laws-they can only expound them,"272 maintained Zephaniah Swift, a Federalist who would later become the Chief Justice of Connecticut. The point he made in this 1795 writing was the same one that pervaded the political thinking at the time: liberty must be eternally guarded from the designs of those claiming power. Hamilton said that " $[\mathrm{t}] \mathrm{o}$ avoid an arbitrary discretion in the courts, it is indispensable that they should be bound down by strịct rules and precedents, which serve to define and point out their duty in every particular case that comes before them . . . ."273

These were old views-extending well back into the colonial period-that judges should have limited discretion and not purport to be legislators. ${ }^{274}$ Much the same rhetoric persists today, and one occasion-

${ }^{267}$ See M. HoRwITz, supra note 49, at 1-30.

${ }^{288}$ See Bowman, The Unconstitutionality of the Rule of Swift v. Tyson, 18 B.U.L. REv. 659, 662 n.9 (1938). By the first half of the 19th century, however, the view of cases as evidence of law was coming under increasing attack. See Kempin, supra note 265 , at 36 .

${ }^{269}$ Letter from John Adams to Hezekiah Niles (Feb. 13, 1818), reprinted in 10 The Works of John Adams, Second President of the United States 283 (C. Adams ed. Boston 1856).

270 See W. CARPENTER, supra note 69, at 34-36.

271 See J. Goebel, Gases and Materials on the Development of Legal INSTITUTIONS 432 (1937).

2721 Z. SWIFT, supra note 265, at 93-94.

273 The Federalist No. 78, at 529 (A. Hamilton) (J. Cooke ed. 1961).

224 See M. HorwITZ, supra note 49, at 12-13. Horwitz argues that the distinguishing feature of the earlier American period was the lack of a perception that the common-law process "endowed judges with the power to be arbitrary." Id. at 13. 
ally doubts whether real theoretical advancement has been made since the days of the early Republic. The problem is inherent to the judicial process in a liberal democracy, and was appreciated then as now. At least in nonconstitutional cases, judges are purportedly controlled by the force of legislative superiority and-in the words of Guido Calabresi- " $[t]$ he incremental nature of common law adjudication."27s

Concerned with justifying judicial decisionmaking, Republican James Sullivan (whose career included being Attorney General, Governor, and Associate Justice of Massachusetts) wrote in 1801:

And who is to decide on the question, whether a principle, urged as law, has heretofore been in practice? The judges are to decide; but yet not in an arbitrary manner. The records of the courts of law will generally witness whether a principle has been in practice in the country; tradition comes in with its aid, and the judges are at all times surrounded with men conversant in the courts of justice, and whose habits start at every new theory that is proposed. In addition to this, the Supreme Judicial Court is always composed of learned, wise and prudent men, who have but one common interest with their fellow citizens, and who have no temptation to do wrong, in a matter of general practice. ${ }^{276}$

Adhering to principles is not the same as acting according to the dictates of the people, who may have expressed themselves through democratic processes. With this in mind, jurists of the late eighteenth century began articulating a new justification, one that, as Horwitz details, was exhibited in diverse writings of the period. ${ }^{277}$ Judicial legitimacy was asserted to rest on popular consent to the process of common-law decisionmaking; in Sullivan's words, the common law was "adopted and established by the common consent of the people."278

Consent is a slippery concept, and this is especially the case when one is using it to legitimize the role of the judiciary. Consent cannot mean popular acceptance of particular decisions. Rather, the consent is to a system that develops principles over time. Recognizing judges as lawmakers-which was being done with increasing frequency in the

278 See G. Calabresi, supra note 48 , at 4 . ton 1801).

276 J. Sullivan, The History of Land Titles in Massachusetrs 340 (Bos-

277 See M. HoRwITz, supra note 49, at 19-22.

278 J. Sullivan, supra note 276 , at 17 . See also 1 Z. SwIFT, supra note 265 , at 40 ("The Common Law derives its force and authority, from the universal consent and immemorial practice of the people."). 
early nineteenth century ${ }^{278}$-is not at all inconsistent with the older view that the decisions of the past have an enormous and influential impact on judges making decisions in the present. After becoming a judge, Swift wrote in 1810:

It is impossible for the wisest Legislature, or ablest Prince, to frame statutes, or edicts, adapted to the circumstances of every case that will occur in the various changes of society. But by this mode, the law grows out of the case, and must be adapted to similar cases. A Legislature must establish a general, unbending rule: Courts possess a discretion of shaping their rules to every possible variety of circumstance. Here then is a vital principle, inherent in the constitution of the judiciary, perpetually operating on cases as they occur, correcting the errors of past ages, borrowing improvements from all countries, and furnishing remedies according to the growing wants, and varying circumstances of men, in their progress from the rudest, to the most civilized stages of society, without waiting for the slow progress of Legislative interference. $^{280}$

Some might read this as a flat endorsement of the instrumental role of judges; ${ }^{281}$ Swift, however, was still very much a man of the past, as evidenced in this next passage:

Though in some cases at first view, it might seem that a more perfect rule than the Common Law might be adopted; and this has sometimes seduced Courts to depart from it; yet when such new rule came to be traced through all its consequences, and applied to the various cases that occurred, the wisdom of the Common Law has been soon discovered, and generally acknowledged. ${ }^{\mathbf{2 8 2}}$

Swift was referring to

[t]he Common Law, [which] has usually been called the

270 See M. HoRwIT, supra note 49, at 1-30.

${ }^{280}$ Z. Swift, A Digest of the Law of Evidence, in Civil and Griminal Cases, and a Treatise on Bills of Exchanges and Promissory Notes, at v-vi (Hartford 1810).

${ }^{281}$ See, e.g., M. HoRwITz, supra note 49, at 23. Horwitz stresses Swift's apparent acceptance of the overruling of precedents, an acknowledgement that had also appeared in Swift's 1795 treatise on Connecticut law. See id. at 25 (citing 1 Z. SwIFT, supra note 265, at 41,46 ). Nevertheless, Swift thought that precedents should rarely be overruled, and that judicial opinions were evidence of what the law is. See infra text accompanying notes $282-84$.

${ }_{282}$ Z. SWIFT, supra note 280 , at viii. 
Common Law of England, to designate its origin; but it may with equal propriety be called the Common Law of America: for our progenitors brought it with them from England, and made it, by adoption, their own, as much as the language they spoke. ${ }^{283}$

As for the process of developing that common law, Swift invoked the traditional idea of law as subject to discovery:

The opinion of able Judges, who have devoted their lives to the study and practice of the law, may be deemed good evidence of what the law is; and it is but truth to say, that the Courts of Westminster Hall have long been adorned by the most eminent characters; and that few cases occur where their descisions [sic] will not be found, on the fullest examination, to be correct deductions from the Common Law, and conformable to the principles adopted in both Countries. ${ }^{284}$

In a broad sense, the ambiguity in Swift's formulation parallels the dilemmas now confronted by writers in legitimizing judicial authority. For example, a popular assertion today is that the judicial process, by relying on formalistic modes of reasoning, moves slowly and incrementally, inevitably retarding responsiveness to social change. ${ }^{285} \mathrm{Ber}-$ nard Bailyn has noted that in the post-colonial period, Americans still appealed to precedent and tradition and assumed that "the accumulation of ages, the burden of inherited custom, contained within it a greater wisdom than any man or group of men could devise by the power of reason." ${ }^{286}$ At the same time, the very notion of relying on

283 Id. at vii.

${ }^{284}$ Id. at ix. Horwitz isolates Swift's remarks on the law of evidence: "The rules of evidence are of an artificial texture, not capable in all cases of being founded on abstract principles of justice. They are positive regulations founded on policy; and . . . they do not profess to be always able to arrive at the truth . . . " Id. at xi, quoted in M. HoRwrTZ, supra note 49, at 25-26. Whether Swift's comment was something that "no jurist would have perceived a quarter of a century earlier," M. HoRwITz, supra note 49 , at 25 , is hard to say and certainly not supported by Horwitz. It is not at all clear that Swift was using "policy" as a 20th century lawyer would; in any event, he was not referring to "all cases" of evidence, and he appeared to assume that many were "founded on abstract principles of justice." Swift may have focused on the law of evidence since most of the rules in that area were of comparatively recent origin-dating to the acceptance of juries as factfinders in the sixteenth century. See 9 W. HoLDsWORTH, A History of ENGish LAw 126-33 (3d ed. 1944). Important changes in evidence law came with the reception of proof of mercantile customs by Lord Mansfield in the late 18 th century. See id. at 132-33.

${ }^{28 s}$ See G. Calabresi, supra note 48 , at 75.

288 B. BAILYN, supra note 64 , at 33. 
tradition was entirely alien to the Enlightenment rationalists whom the early Americans quoted, as we still do, "with equal enthusiasm."28z

A similar problem for both the 1790's and today was the association of judicial lawmaking with ex post facto legislation. The petit jury charge in Henfield stressed that the defendant was guilty of a crime that had been recognized for many years. ${ }^{288}$ Soon thereafter, Swift-who hardly had Republican leanings-wrote that punishment by way of a common-law criminal "proceeding manifestly partakes of the odious nature of an ex post facto law, and subjects a man to an inconvenience which he could not possibly foresee, or calculate upon, at the time of doing the act." ${ }^{\text {"289 }}$ Although he could not demonstrate any abuse of "this discretionary power" in Connecticut, Swift nevertheless considered it more prudent to leave the task of defining crimes to the legislature:

There certainly is danger to be apprehended from the exercise of such power in times of convulsions, when the spirit of party runs high: for then it is very possible that courts, influenced by political prejudice, might punish with great severity, actions which are very innocent in a moral view. ${ }^{290}$

${ }^{287}$ Id. An excellent example of the combination of Enlightenment optimism in human rationality with an appeal to tradition is this excerpt from a 1794 grand jury charge by Justice Iredell:

We have the happiness to live in an age when human knowledge in all its branches has been carried to a great perfection. The Law of Nations, by which alone all controversies between nation and nation can be determined, has been cultivated with extraordinary success. In its main principles, as stated by many able writers all civilized nations concur. . . . Within these few years this law has not only been stated with peculiar accuracy and conciseness, but all its principles have been traced to their sources with a power of reasoning which has commanded universal assent, and with a spirit of freedom and an enlarged liberality of mind entirely suited to the high improvements the present age has made in all kinds of political reasoning.

Charge to the Grand Jury for the District of South Carolina (May 12, 1794), supra note 249.

${ }^{288}$ See Henfield, $11 \mathrm{~F}$. Cas. at 1120.

289 2 Z. SwIFT, supra note 265, at 365-66.

$290 \mathrm{Z}$. SwIFT, supra note 280 at vii. Horwitz is quite right in reading Swift's argument as indicative of an awareness of the lawmaking powers of judges. See HoRwITZ, supra note 49 , at 14 . Horwitz also correctly cautions that "Swift clearly did not abandon the natural law framework within which common law crimes traditionally had been understood." Id. Horwitz, however, thinks that historians have not fully appreciated the underlying change in the conception of law by the early jurists due to "an excessive preoccupation with the political and constitutional dimensions of the struggle over common law crimes." Id. at 11. Separating causes from effects is not that easy. Swift, for example, was obviously concerned with judicial discretion because of its possibility for political abuse. 
Further complicating the jurisprudential question of retrospective rulemaking was the uncertainty over the content of American law, ${ }^{291}$ a difficulty engendered by the lack of case reports ${ }^{292}$ and the unresolved debate over how much English law had been received in the new country. ${ }^{283}$

The dilemma in Henfield is one inherent in a system that is devoted simultaneously to consensual politics and rational decisionmaking. In any era, relying solely on majoritarianism will hardly be conducive to the systematic planning and coordination of governmental functions. Most of the nation's leaders who had lived through the 1780 's were not inclined to give the people such a significant voice in decisions. Nonetheless, the people could not be ignored, and the literature of the period was rife with tributes to popular governance. Eventually this conflict advanced to an inquiry into the nature of judicial power itself. For a citizenry disposed by years of hard experience to believe that power inevitably corrupted, and that political actors tended toward conspiracy, the early Americans were especially likely to link a judicial act with the public affairs of the day. This is certainly what the opposition press did in reaction to the Henfield prosecution. Arguments about the degree of connection between the judicial and political processes have continued to this day. Ordinarily it is the particular judicial decision, made by a certain group of judges, that provokes public controversy.

To understand the issue of the common-law jurisdiction of federal courts, however, attention must not be focused exclusively on the in-

291 See L. KERBER, supra note 146, at 138. See also Hall, The Common Law: An Account of Its Reception in the United States, 4 VAND. L. REv. 791, 805 (1951) (noting that all of the states adopted the rule that they would recognize only the principles of common law that were applicable to local situations). A common complaint of judges in those days was the lack of authoritative guidance. See 2 H. Flanders, The Lives and Times of the Chief Justices of The Supreme Court of the United STATES 119 (2d ed. 1881) (quoting the preface to Kirby's Reports on the uncertainty of the state law of Connecticut when Oliver Ellsworth was appointed to the Superior Court of Connecticut); 1 W. CROSSKEY, supra note 61, at 606 (quoting James Kent on his career as chancellor in New York: "I had nothing to guide me \& was left at liberty to assume all such English chancery powers and jurisdiction as I thought applicable under our constitution.").

292 See 2 A. Chroust, The Rise of the Legal Profession in America 72-75 (1965); R. Ellis, supra note 71, at 191; J. Sullivan, supra note 276, at 19.

${ }^{293}$ See E. Brown, British StatuTeS in American Law 1776-1836, at 30-31 (1964); Howe, The Process of Outlawry in New York: A Study of the Selective Reception of English Law, in Essays IN THE History of EARLy AMERICAN LAw 433, 433-38 (D. Flaherty ed. 1969); Pope, supra note 265, at 6-7. Zephaniah Swift complained in 1795 that "for want of some general rule" to establish when British law was received, "[t]he student . . . finds himself forever embarrassed with doubt and uncertainty ..." $1 \mathrm{Z}$. SwIFT, supra note 265 , at 2 . 
creasing perception that judges were in fact making the rules. The common-law process would dominate American law until well into the nineteenth century, notwithstanding the frequent cries for codification. ${ }^{294}$ Blackstone would be read widely by lawyers and cited by judges throughout the century, ${ }^{208}$ and states continued to prosecute common-law crimes long after Hudson. ${ }^{286}$ In so doing, the states were supported by jurists such as Chancellor Kent, who said in 1826:

It is impossible to define expressly and literally every offence that ought to be punished; and if you ask me what is the evidence of its being an offence if not defined in the code, I answer, the laws of nature, of religion, or morality, which are written on the heart of every son and daughter of Adam, declare the offence ....297

That the reaction to Henfield was mainly a product of its political subject matter is further demonstrated by United States $v$. Ravara. ${ }^{288}$ Joseph Ravara, the consul from Genoa, was indicted in the Circuit Court in Philadelphia one day before the true bill was returned in Henfield, and tried a year later on a charge of attempting to extort money from the British Minister, Hammond. ${ }^{289}$ While some commentators have assumed that the prosecution was based solely on the common law, ${ }^{300}$ a statutory basis for the prosecution could have been found in a 1790 criminal statute that made it an offense to "assault, strike, wound, imprison, or in any other manner infract the law of nations, by

204 Representative John Stanley remarked before Congress in 1802 that "[n]inetenths of the decisions in our State courts and Federal courts turn on questions of common law ...." 11 ANNALs of Cong. 573. Many commentators have recognized that this factor (along with a dislike of the common-law method itself) was behind the call for codification in the 1820's and later. See F. AumanN, supra note 151, at 121 n.5; 2 A. Chroust, supra note 292, at 52-54.

205 See R. Summers, Instrumentalism and American Legal Theory 13940 (1982).

208 See Anonymous, The Extent to Which the Common Law is Applied in Determining What Constitutes a Crime, and Nature and Degree of Punishment Consequent Thereupon (pt. 1), 6 AM. L. Rev. 65, 77 (1866); Anonymous (pt. 2), supra note 251, at 339. Even in the case of statutes that expressly proscribed a crime, such as murder, the definition of the crime was frequently left to the common law in 19th century prosecutions. See, e.g., id. at 323-24.

${ }^{297}$ Letter from James Kent to Edward Livingston (Mar. 13, 1826), reprinted in 16 AM. JuRIST 363 (1837). In his Commentaries, Kent wrote that "the common law, under the correction of the constitution and statute law of the United States, would seem to be a necessary and safe guide, in all cases, civil and criminal, arising under the exercise of [federal] jurisdiction, and not specially provided for by statute." $1 \mathrm{~J}$. KENT, supra note 264 , at $320-21$.

20827 F. Cas. 713 (C.C.D. Pa. 1794) (No. 16,122).

${ }^{299}$ See J. GoEbel, supra note 59, at 627 \& nn. 72-75.

soo See, e.g., L. LEVY, supra note 52, at 276; Presser, supra note 55, at 56. 
offering violence to the person of an ambassador or other public minister ."301 The defense objected in part that the act alleged was "not a crime by the common law, nor is it made such by any positive law of the United States." federal jurisdiction to the case. Justice Wilson and Judge Peters ruled against a motion to quash the indictment for lack of jurisdiction, and Justice Iredell dissented on the ground that the case was within the exclusive original jurisdiction of the Supreme Court. ${ }^{303}$ At the trial, Chief Justice Jay and Judge Peters instructed the jury that "the offense was indictable," and Ravara was convicted. ${ }^{304}$ Although Ravara is most accurately read as a case in which the elements of a broad criminal statute were particularized through a common-law process, ${ }^{305}$ there seems to have been little adverse comment on the judicial lawmaking that was occurring in the trial. ${ }^{306}$ The defense apparently accepted the necessity to argue that there had been no common-law crime committed. To the extent that the issue of federal common-law adjudications became a public issue, it arose when the case itself involved a political

s01 Act for the Punishment of Certain Crimes against the United States $\S 28,1$ Stat. 112, 118 (1790); see J. GoEBEL, supra note 59, at 627. The odd thing, however, is that the prosecutor-William Rawle-later argued in United States v. Worrall, 28 F. Cas. 774, 778 (C.C.D. Pa. 1798) (No. 16,766), that Ravara, "although he held the office of a consul, . . . was indicted and punished at the common law." Since Rawle was citing Ravara to support a nonstatutory prosecution, see infra text accompanying notes $322-23$, he at least was insisting to the Worrall court that the earlier case was entirely a common law prosecution. The district judge-Richard Peters-was the same in both cases, but in Worrall he made no mention of Ravara. See Worrall, 28 F. Cas. at 779-80. Apparently Rawle meant that the statute required a common-law definition for the elements of the offense.

${ }^{302}$ Ravara, 27 F. Cas. at 714.

sos Id.

so4 Id. at 715.

sos For a similar interpretation of Ravara, see Anonymous (pt. 2) supra note 251 , at 132-33 (stating that "the question of the national courts having a common-law jurisdiction where offenses were not otherwise created or declared by the constitution or by statute, was not one adverted to in Ravara").

${ }^{308}$ Another case of a federal common-law prosecution after Henfield that seems to have provoked little public outcry is United States v. Smith, 27 F. Cas. 1147 (C.C.D. Mass. 179[7]) (No. 16,323). Chief Justice Ellsworth was on the panel with Judge John Lowell. Smith was an action for counterfeiting bills of the Bank of the United States, an action which was not covered by a statute. In discussing jurisdiction, the case as reported seems to indicate that the court based its authority solely on the Constitution:

The Court held . . . that by the constitution of the United States the federal courts had jurisdiction of all causes or cases in law or equity arising under the said constitution and the laws of the United States; that this was a case arising under those laws, for those bills were made in virtue thereof, though there was no statute describing or punishing the offense of counterfeiting them; and therefore to counterfeit them was a contempt of and misdemeanor against the United States, and punishable by them as such.

Id. at 1147-48. 
controversy:

To be sure, the Henfield judges were preoccupied with justifying what they were doing. A more important objective, however, was to articulate a federal role in controlling foreign relations. There was an interesting convergence of the positions taken by the Administration and the various federal judges involved in the neutrality prosecutions. Aside from formal action, Chief Justice Jay took the step (along with Senator Rufus King) of giving the press a notice to the effect that Genêt had threatened "to appeal from the President to the people."soz None of this is surprising considering the gravity of the issues involved and the fact that the country was hardly in a position to take part in the European war. A primary motivation for calling the constitutional convention had been the lack of unity in foreign affairs, a critical aspect of which was the failure of many states to honor the Confederation's treaty obligations. This had been an extremely serious issue, for many felt that renewed war was inevitable if the flaws of the Articles of Confederation were not dealt with decisively. ${ }^{308}$ There was even a proposal before the Congress in 1786 to amend the Articles and create a federal court of appeals to resolve disputes between states and foreign countries by applying the law of nations. ${ }^{300}$

As Madison explained to the Virginia Convention, a central purpose of the federal judiciary was to provide "exclusive jurisdiction" over matters respecting treaties such that they would receive a "uniform" exposition. ${ }^{310}$ Since the actions of citizens directly risked involving America with the European conflict, it was not at all extraordinary for a Federalist judiciary to assist the Administration through the accepted route of common-law prosecutions. When the judges asserted that the law of nations had defined Gideon Henfield's offense before he was born, they were saying the same thing as George Nicholas had argued during the ratification debates-"the law of nations was permanent and general."s11

The reaction of the opposition press was consistent with long-

${ }^{307}$ See D. MALONE, supra note 115, at 135.

${ }^{308}$ See F. Marks, Independence On Trial: Foreign AfFairs and the Making of The Constitution 1-51 (1973). The Confederation Congress was unable to enforce states' compliance with treaties, as it lacked both the "exclusive control of foreign relations" and "an independent source of revenue." See id. at 47.

${ }^{309}$ See id. at 15.

s10 See 3 Elliot's DeBates, supra note 138, at 532. Hamilton had similarly identified cases involving "the PEACE of the ConfeDeracy, whether they relate to the intercourse between the United States and foreign nations, or to that between the States themselves," as one of the main objects of federal judicial authority. See THE FEDERALIST No. 80, at 534 (J. Cooke ed. 1961).

s11 3 Ellior's Debates, supra note 138, at 502 (Virginia Convention). 
standing traditions. The court's explicit charge that Henfield was guilty prompted a flood of ink alleging that "policy" was being introduced into judicial affairs ${ }^{312}$-an entirely reasonable conclusion. The opposition's real complaint, however, was with the policy itself, one that in practice favored what it saw as detrimental to the interests of America's natural ally, France. That the opposition may have been more concerned with foreign affairs than the role of the judiciary is evidenced by Republican efforts to advance their own causes in the courts. One of Henfield's attorneys, Jared Ingersoll, who was also the Attorney General of Pennsylvania, presented a bill of indictment to a Philadelphia County grand jury in 1797, charging William Cobbett, the editor of the Federalist (and stridently anti-Jeffersonian) Porcupine's Gazette, with common-law criminal libel. ${ }^{313}$ The Federalist majority on the grand jury refused to indict, while Republican members asked for a true bill. ${ }^{314}$

312 See supra text accompanying notes 241-43.

s13 See F. Wharton, supra note 91 , at 322,326 (Pa. Oyer \& Terminer 1797) (Trial of William Cobbett). Cobbett was charged with libel against the Spanish King and his minister to the United States. Chief Justice Thomas McKean of the Pennsylvania Supreme Court (a leading Republican who was to become the father-in-law of the Spanish envoy in question) charged the Grand Jury:

Every one who has in him the sentiments of either a Christian or gentleman, cannot but be highly offended at the envenomed scurrility that has raged in pamphlets and newspapers, printed in Philadelphia for several years past, insomuch, that libelling has become a kind of national crime, and distinguishes us not only from all the States around us, but from the whole civilized world. Our satire has been nothing but ribaldry and Billingsgate: the contest has been, who could call names in the greatest variety of phrases; who could 'mangle the greatest number of characters; or who could excel in the magnitude and virulence of their lies. Hence the honour of families has been stained; the highest posts rendered cheap and vile in the sight of the people, and the greatest services and virtue blasted. This evil, so scandalous to our government, and detestable in the eyes of all good men, calls aloud for redress. To censure the licentiousness is to maintain the liberty of the press.

At a time when misunderstandings prevail between the Republics of France and the United States, and when our General Government have appointed public ministers to endeavour their removal, and restore the former harmony, some of the journals or newspapers in the City of Philadelphia, have teemed with the most irritating invectives, couched in the most vulgar and opprobrious language, not only against the French nation and their allies, but the very men in power with whom the ministers of our country are sent to negotiate. These publications have an evident tendency not only to frustrate a reconciliation, but to create a rupture, and provoke a war between the sister republics, and seem calculated to vilify, nay, to subvert all republican governments whatever.

Id. at 324-25.

314 See id. at 329 (Wharton's notes). A libel prosecution was also brought against Cobbett in federal court, but again the grand jury refused to indict. See id. at 329 (quoting Porcupine's Gazette). For Attorney General Charles Lee's opinion that Cob- 
When Henfield came down, the controversy over federal commonlaw jurisdiction was still in an embryonic stage. Yet the suggestion had been made that the court was exceeding its power under the Constitution; Federalists responded to the attack, and from there a constellation of issues began to form. And the players changed roles as the events unfolded. Thomas Jefferson and Edmund Randolph themselves would turn against nonstatutory prosecutions, at least by the federal government. Jefferson, who had endorsed the trial of privateers such as Henfield, would react quite differently when subsequent prosecutions turned toward those more dear to his own interests.

\section{Justice Chase and the Worrall Prosecution}

The only known dissenting voice among Federalist judges after 1793 to federal common-law jurisdiction was that of Justice Chase. Chase made his view known in United States $v$. Worrall, ${ }^{315}$ which came to the circuit court at Philadelphia in April of 1798. Robert Worrall had been indicted for attempting to bribe Tench Coxe, the commissioner of the revenue, for the purpose of obtaining a contract on a federal construction project. One of Worrall's defense counsel, Alexander J. Dallas, contended that the jury's verdict of guilty should be arrested since there had been no asserted "violation of some constitutional or legislative prohibition." ${ }^{316} \mathrm{He}$ then anticipated the government's argument, that the crime was punishable at common law; the Constitution, Dallas reasoned, contained

no reference to a common-law authority: Every power is [sic] matter of definite and positive grant; and the very powers that are granted cannot take effect until they are exercised through the medium of a law. Congress had undoubtedly a power to make a law, which should render it criminal to offer a bribe to the commissioner of the revenue; but not having made the law, the crime is not recognized by the federal code, constitutional or legislative; and, consequently, it is not a subject on which the judicial authority of the Union can operate. ${ }^{317}$

bett was indictable in federal court, see Letter from Charles Lee to Philip Fatio (July 27, 1797), reprinted in 1 Official OpINIONS OF THE ATtORNEYs GeNERAL OF THE UNITED States 71-74 (B. Hall ed. Washington, D.C. 1857).

${ }^{315} 28$ F. Cas. 774 (G.C.D. Pa. 1798) (No. 16,766). A thorough account of Worrall is found in Presser, supra note 55, at 58-72.

s16 Worrall, $28 \mathrm{~F}$. Cas. at 776.

s17 Id. at 777-78. 
In response, William Rawle candidly admitted that he was supporting the indictment "solely at common law."318 The United States Attorney's address concentrated mainly on the necessity for the prosecution. Rawle characterized it as a matter that "struck at the root of the whole system of the national government; for, if opposition to the pure, regular and efficient administration of its affairs could thus be made by fraud, the experiment of force might next be applied; and doubtless, with equal impunity and success." ${ }^{319}$ With respect to Dallas' constitutional objection, he replied that there was no problem, "for the offence was strictly within the very terms of the constitution, arising under the laws of the United States." ${ }^{320}$ By this he meant that if the office held by the commissioner had not

been created by the laws of the United States, no attempt to corrupt such an officer could have been made; and it is unreasonable to insist, that merely because a law has not prescribed an express and appropriate punishment for the offence, therefore, the offence, when committed, shall not be punished ... upon the principles of common law punishment. $^{321}$

Rawle cited Henfield and Ravara for authority, claiming that both had involved punishments imposed under the common law. ${ }^{322}$ Finally, without federal competence to proceed via common-law prosecutions, these cases would go unpunished: they were "not cognizable before any state tribunal."323

Justice Chase interrupted Rawle's presentation and launched into a speech that, as Francis Wharton later recounted, "appear[ed] to have greatly surprised not only the bar but the community." 324 Chase flatly denied that the indictment could "be maintained in this court."325 To understand Chase's opinion in Worrall, it must be remembered that he was once a strident Antifederalist who had opposed ratifying the Constitution. ${ }^{328}$ Although by the time in question he had turned to the Fed-

${ }^{318} I d$. at 778 . The quoted words are actually part of a question from Justice Chase, which Rawle answered "in the affirmative."

sig $I d$.

320 Id.

321 Id.

$322 I d$.

323 Id. Although Rawle cited no authority for this proposition, he was referring to the provisions for exclusive federal jurisdiction over criminal cases under the $1789 \mathrm{Ju}$ diciary Act. See supra note 59.

324 F. WHARTON, supra note 91, at 199 n.*.

328 Worrall, 28 F. Cas. at 778.

${ }^{328}$ See J. GoEBEL, supra note 59, at 368-69 (Chase "was a confederation man 
eralist party, his Worrall opinion reflected a deep-seated states' rights philosophy. ${ }^{327}$

Many of Chase's arguments in Worrall would be reiterated by the Court in Hudson with only slight modification. Chase began with an account of the narrow sweep of federal authority: "[T]he constitution of the Union is the source of all the jurisdiction of the national government; so that the departments of the government can never assume any power, that is not expressly granted by that instrument, nor exercise a power in any other manner than is there prescribed."328 The question for Chase, then, was "when and how have the courts of the United States acquired a common law jurisdiction in criminal cases?"329 Chase succinctly listed the only ways in which the United States might possess the common law: "Now, the United States did not bring it with them from England; the constitution does not create it; and no act of congress has assumed it."

While Chase claimed that the United States had no common law and thus could not maintain indictments at common law, his position with respect to the states was entirely different. Chase's views on state

because he was passionately devoted to his state. He thought that the difficulties of the Union . . . could be resolved if the states did their duty." Id. at 369); Presser, supra note 55, at 73 ("Chase's sensitivity to Maryland popular opinion, or possibly his sincere feelings about concentrated and centralized aristocratic authority, led him to become a vehement opponent of the proposed Federal Constitution on the grounds that it too tightly constricted the sovereignty of the individual states." (footnotes omitted)). See generally 5 The Complete ANTI-Federalist 79-91 (H. Storing ed. 1981) (Chase's speeches at Maryland ratifying convention).

${ }^{327}$ See Presser, supra note 55, at 73-74 ("Chase's view in Worrall, then, rather than highlighting a new conception of jurisprudence, probably reflects Chase's old style of politics."). A new account of Chase's career by the same author emphasizes his deeply rooted Southern conservatism and religious convictions as an explanation for the Justice's siding with the Federalists despite his strong belief in state independence. See Presser \& Hurley, Saving God's Republic: The Jurisprudence of Samuel Chase, 1984 U. ILL. L. REV. 771.

${ }^{328}$ Worrall, 28 F. Cas. at 779. The use of the word "expressly" was itself very controversial. In voting on the proposed tenth amendment, Congress had deliberately omitted that exact word, which had appeared in the Articles of Confederation. See U.S. ART. Confed. art. 4, 1 Stat. 4 (1778). Representative Thomas T. Tucker of South Carolina moved on August 18, 1789, "to add the word 'expressly,' so as to read 'the powers not expressly delegated by this Constitution." "Madison then "objected ... because it was impossible to confine a Government to the exercise of express powers; there must necessarily be admitted powers by implication unless the Constitution descended to recount every minutiae." 1 ANNALS OF CoNG. 761 (J Gales ed. 1789). Tucker's amendment was defeated without recorded vote. Three days later Representative Eldridge Gerry made the same motion, and requested the yeas and nays. The motion lost, 32 to 17. Id. at 767-68. Much the same occurred on the Senate side. See Journal of the First Session of the Senate of the United States 122 (New York 1789).

${ }^{329}$ Worrall, 28 F. Cas. at 779.

s30 Id. 
common law would become a mainstay of Republican arguments in the near future:

When the American colonies were first settled by our ancestors, it was held, as well by the settlers, as by the judges and lawyers of England, that they brought hither, as a birth-right and inheritance, so much of the common law as was applicable to their local situation and change of circumstances. But each colony judged for itself what parts of the common law were applicable to its new condition; and in various modes by legislative acts, by judicial decisions, or by constant usage, adopted some parts, and rejected others. Hence, he who shall travel through the different states, will soon discover, that the whole of the common law of England has been nowhere introduced; that some states have rejected what others have adopted; and that there is, in short, a great and essential diversity in the subjects to which the common law is applied, as well as in the extent of its application. The common law, therefore, of one state, is not the common law of another; but the common law of England, is the law of each state, so far as each state has adopted it; and it results from that position, connected with the judicial act, that the common law will always apply to suits between citizen and citizen, whether they are instituted in a federal or state court. $^{\text {331 }}$

In contrast to the specific state receptions of the common law, nothing similar had transpired at the federal level. "Besides, what is the common law to which we are referred? Is it the common law entire, as it exists in England; or modified as it exists in some of the states; and of the various modifications, which are we to select . . . ?'332

All of the contentions made by Chase in Worrall revolve around a single conception of the issue presented: the common law was envisioned as a body of unwritten law, which must be received in whole or in part in order for a court to have jurisdiction over the case. An identical attitude was to be revealed in subsequent discussions by Republicans about the common law in federal courts.

$331 I d$.

392 Id. It has been contended that Chase reversed his position on common-law crimes when he presided over United States v. Sylvester, an unreported 1799 prosecution for counterfeiting. See L. Levy, EMERGence of A Free Press 278 (1985); Presser, supra note 55, at 69. But it seems likely that the case was brought under the newly passed counterfeiting statute, An Act to Punish Frauds Committed on the Bank of the United States, 1 Stat. 573 (1798). 
Judge Peters in a separate opinion in Worrall offered a competing view of the nature of the common law. This opinion summarized the Federalist position:

Whenever a government has been established, I have always supposed, that a power to preserve itself, was a necessary and an inseparable concomitant. But the existence of the federal government would be precarious, and it could no longer be called an independent government, if, for the punishment of offences of this nature, tending to obstruct and pervert the administration of its affairs, an appeal must be made to the state tribunals, or the offenders must escape with absolute impunity. The power to punish misdemeanours is originally and strictly a common law power; of which I think the United States are constitutionally possessed. It might have been exercised by congress in the form of a legislative act; but it may also, in my opinion, be enforced in a course of judicial proceeding. Whenever an offence aims at the subversion of any federal institution, or at the corruption of its public officers, it is an offence against the well-being of the United States; from its very nature, it is cognizable under their authority; and, consequently, it is within the jurisdiction of this court, by virtue of the 11th section of the judicial act. ${ }^{333}$

Peters made no mention of Chase's argument regarding the absence of a federal reception of the English common law. For Peters and other Federalists this was irrelevant. Rather than distinguish between the essential natures of federal and state governments, Peters maintained that all governments possessed the inherent power of protecting their interests-especially when self-preservation was a concern.

These conflicting stances on common-law jurisdiction of the federal judiciary would be repeated often in subsequent debates, but the clash in Worrall exposed the basic demarcation. Republicans would insist throughout the coming era that the federal government and the states were fundamentally different. They believed that only the states possessed the attributes of sovereignty necessary for the reception of the common law. Republicans would concede that state governments could recognize common-law offenses as incident to the sovereign duty of preserving order and perpetuating the government. Allowing the federal

sss Worrall, 28 F. Cas. at 779-80 (Justice Chase and Judge Peters were the only judges sitting on the case.). 
courts to take similar steps would violate the notion that the national powers were confined to those that were explicitly listed in the Constitution.

Republicans such as Alexander Dallas were quick to condemn the theory of "protective" federal common-law crimes as an illustration of "the constant disposition of power to extend the sphere of its influence." "s84 If this precedent were established, Dallas predicted, "[a] mere fiction" could be invoked to expand tremendously the jurisdiction of the circuit courts. ${ }^{\text {s95 }}$ Under English practice, "the jurisdiction of the King's Bench" was made "universal in all personal actions" through the fiction of supposing "that the defendant is in the custody of the marshal." "336 Similarly, "[a]nother fiction, which states the plaintiff to be a debtor of the crown, gives cognizance of all kinds of personal suits to the exchequer ...."ss7 If a common-law action were permitted in Worrall, "it may hereafter be sufficient to suggest, that the party is a federal officer, in order to enable this court to try every species of crime, and to sustain every description of action."388 Dallas was concerned with something larger than the immediate outcome for his client. For him and other Republicans the contest was not an isolated case, but an ongoing series of events that would continuously test the respective roles of the state and federal governments.

Chase would never completely align himself with Republicans on the theory of a radically limited federal government; he was much more willing than the typical Jeffersonian to imply powers to the national establishment. In the ensuing years, one imagines that Chase, as a fiercely partisan Federalist, was somewhat mortified to find his opinion in Worrall used by the opposition to their advantage-which it soon was. It would be wrong, however, to surmise that Chase's dissent indicated widespread disagreement among Federalists on the question of the common law. Once actions were brought on explicitly nonstatutory grounds after 1793, Chase is the only known Federalist judge to diverge from the generally accepted stance that these prosecutions were proper. ${ }^{33 \theta}$

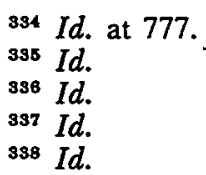

s39 According to Morton Horwitz, Chase's Worrall opinion was proof that the issue of federal common-law jurisdiction went beyond partisan politics to encompass a general "decline in the authority of the common law." M. HoRWITZ, supra note 49, at 11. In support of his position, he stresses Chase's statement "that it was 'essential that congress should define the offences to be tried, and apportion the punishments to be inflicted." Id. at 12 (quoting Worrall, 28 F. Cas. at 779) (minor discrepancies be- 
As for Worrall, he was sentenced to a fine and imprisonment when he refused the judges' suggestion that he "put [the case] into such a form, as would admit of obtaining the ultimate decision of the supreme court, upon the important principle of the discussion." 340 Given that Worrall had little hope of persuading the higher court, his disinclination to seek review is understandable. Moreover, by avoiding the Supreme Court, Alexander Dallas also prevented that body from entering an authoritative precedent on common-law jurisdiction. As fate would have it, that honor was reserved until Hudson, by which time the Court's personnel were quite different.

\section{B. Maturing of the Controversy over Federal Common Law: The Alien and Sedition Acts}

In the years between Henfield and Worrall there were a number of prosecutions for neutrality violations under the common law and law of nations, ${ }^{341}$ others were indicted on charges of treason. ${ }^{342}$ And common-law prosecutions were brought for such offenses as counterfeiting and seditious libel. ${ }^{343}$ With the passage of the neutrality legislation, however, the matter of federal common-law crimes seems to have faded

tween Horwitz's text and the original have been corrected)). The context of Chase's remark, however, indicates that he was not thinking primarily about the dangers of judicial lawmaking. His reference to congressional control was solely in regard to the manner in which the Constitution had apportioned powers to the national government. By underscoring the need for legislative action-which had to be justified under an "express" power of Congress-he was demonstrating the sharp limitations on federal sovereignty. In any event, to view Chase as a harbinger of concern for judicial instrumentalism is questionable when he was widely despised for purportedly abusing his authority in Sedition Act cases. See N. SchachNER, supra note 162, at 480-81 (describing Chase as " $[\mathrm{g}$ g]ross of feature, heavy-jowled, a furious Federalist who conceived all Republicans to be the spawn of hell . . [ [H]is bullying tactics, his violent and partisan charges, his intimidation of defendants, witnesses, lawyers and jurymen, made him the most hated judge of the time."). Further, as Professor Presser has pointed out, Chase's opinion that same year in Calder v. Bull, 3 U.S. (3 Dall.) 386, 386-95 (1798) displays the marks of one who firmly believed in the concept of natural law as a limiting force on government. See Presser, supra note 55, at 68 .

${ }^{340}$ Worrall, $28 \mathrm{~F}$. Cas. at 780 . Since the court split on a motion to arrest judgment, the imposition of sentence does not mean that Chase agreed with the conviction. n.2.

${ }_{341}$ See J. GoebeL, supra note 59, at 626; 1 C. WARREN, supra note 38, at 115

342 See, e.g., United States v. Villato, 28 F. Cas. 377 (C.C.D. Pa. 1797) (No. 16,622). Villato was accused of capturing an American vessel; Justice Iredell and Judge Peters dismissed the charges on the ground that the defendant was not an American citizen. See id. at 378-79. The Whiskey Insurgents had also been charged with treason, see United States v. Insurgents of Pennsylvania, 26 F. Cas. 499 (C.C.D. Pa. 1795) (No. 15,443), which was a statutory offense, see An Act for the Punishment of Certain Crimes Against the United States, ch. 9, § 1-2, 1 Stat. 112, 112 (1790), but one that drew heavily on common-law definition.

s43 See supra note 306 and infra notes $351-52$ and accompanying text. 
briefly from the limelight. The grand jury charges from this period usually refer to statutory offenses or vaguely invoke national law or the law of nations. ${ }^{344}$ But this was at best a momentary lull, for the federal judiciary was about to enter its most serious crisis to date.

Following the scandalous $\mathrm{XYZ}$ affair, a wave of patriotic fervor swept the country, and Republicans and their presses became the objects of verbal and physical abuse. ${ }^{345}$ Even before then, federal grand jury charges had grown progressively more strident in tone, and bitterly denounced what was perceived to be a storm of national disunity. "Let then, the man, or combination of men," said Chief Justice Ellsworth, "who, from whatever motive, oppose partial to general will, and would disjoint their country to the sport of fortune, feel their impotence and error." ${ }^{346}$ Nor did they shirk from accusation. Justice Paterson warned a grand jury:

Our own country, and indeed, all free countries, have exhibited signal and melancholy proofs, how prone the people are to be seduced, irritated, and convulsed by the misrepresentations and artifices, the wicked machinations and schemes, or the open and bold attempts and enterprizes of factions, unprincipled designing and ambitious men. ... Hence seditious language, writings, and actions. Hence riots, tumults and insurrections. ${ }^{347}$

For Iredell, the very future of the nation was at risk; he saw the partisan politics of the times as "inviting some foreign nation to foment and take advantage of our internal discords, first making us the dupe and

s4t See, e.g., Charge to the Grand Jury for the District of Connecticut (May 12, 1795) (Iredell, J.), reprinted in Connecticut Journal (New Haven), July 29, 1795 (expecting "no ... important business," and referring generally to the law of nations and the "laws of the United States"); Charge to the Grand Jury for the District of Rhode Island (Nov. 7, 1794) (Cushing, J.), reprinted in Providence Gazette and Country Journal, Nov. 15, 1794 (referring to the crime of treason, acts against treaties, "violations of the law of revenue," and "murder, piracies, felonies and violences committed upon the high seas, in prejudice of natural rights, and of the safety of the navigation and commerce, \&. \&."); Charge to the Grand Jury for the District of Delaware (Oct. 27, 1794) (Blair, J.), reprinted in The Diary (New York), Nov. 10, 1794 (mentioning only federal legislation as grounds for indictment).

s6s See L. BANNING, supra note 77, at 253-54.

s46 Charge to the Grand Jury for the District of Georgia (Apr. 25, 1796), reprinted in Columbian Museum (Savannah), Apr. 29, 1796.

347 Grand Jury Charge, W. Paterson, Paterson Papers (n.p., n.d.), [original in Rutgers University Library (quoted with permission); copy on file with the University of Pennsylvania Law Review]. Although it is unclear when or where the charge was given, or if it was merely a draft, the subject matter of the writing suggests that it dates from no earlier than 1796. 
then the prey of ambition we excited by our divisions."348 Some judges, moreover, were convinced that French-inspired insurrection was already underway, and linked the Whiskey Rebellion to the "inflammatory and impudent publications of the democratic societies, set up by Mr. Genêt to overthrow the federal union."349

One consequence of these Federalist fears was the passage of the Alien and Sedition Acts. These acts in turn would add another level to the complexity of the dispute over the relationship of the common law to the federal courts.

\section{The Alien and Sedition Acts in Congress}

The precise motivation for passage of the Sedition Act may at first seem a bit mysterious, since common-law prosecutions would accomplish the same end. As was alluded to above, ${ }^{350}$ Federalists had been bringing sedition prosecutions at common law for several years, both in federal and state courts, against well-known Republican editors, causing the demise of a number of publications. ${ }^{351}$ Only days before the Act

s48 Charge to the Grand Jury of the District of Maryland (May 8, 1797), reprinted in Maryland Gazette (Annapolis), May 18, 1797.

s49 Charge to the Grand Jury for the District of Virginia (Nov. 23, 1798) (Cushing, J.), reprinted in Federal Gazette (Baltimore), Dec. 6, 1798. Cushing's jury charge included a review of the history of the French Revolution, and he warned that other countries had fallen under France's control by "their imprudent listening to artful incendiary intrigues, to false, flattering promises of fraternity and protection held out to allure all people to revolt from their governments; thus duping them to their own destruction." Id.

Other references to the Whiskey Rebellion include: Charge to the Grand Jury for the District of Pennsylvania (Apr. 12, 1796) (Iredell, J.), reprinted in Claypoole's American Daily Advertiser (Philadelphia), Apr. 18, 1796; Charge to the Grand Jury for the District of Pennsylvania (Apr. 11, 1799) (Iredell, J.), reprinted in Claypoole's American Daily Advertiser (Philadelphia), May 17, 1799; Opinion of Justice William Paterson, W. Paterson, supra note 243, at 549.

sso See supra text accompanying note 160.

so1 See L. BANNING, supra note 77, at 256-57; J. GoeBEL, supra note 59, at 629, $632-33$; N. SCHACHNER, supra note 162 , at 477 ; J. SMITH, supra note 161 , at $188-$ 220, 385-90.

In 1794 Attorney General William Bradford issued an official opinion that the editor of Greenleaf's New York Journal could be prosecuted for libelling the British minister. See 1 Official OpINions of the AtToRneys General of THE United states 52-53 (B. Hall ed. 1857). Thomas Greenleaf was first indicted in April 1795 in the circuit court for the District of New York, with Justice Iredell and Judge John Lawrence presiding; historians have generally assumed that this case was a commonlaw proceeding. Iredell's grand jury charge, however, used language from a 1793 charge, where he said that it was "peculiarly proper" for the legislature to define crimes. Charge to the Grand Jury for the District of New York (Apr. 6, 1795), reprinted in Gazette of the United States (Philadelphia), Apr. 16-17, 1795. Iredell likely meant that the 1790 Act used in Ravara was applicable to Greenleaf. See supra note 301 and accompanying text. The 1795 charge does speak of "insult or injury" to a foreign minister as a violation of the law of nations, which conceivably could bring it 
became effective, the Republican editor Benjamin Franklin Bache was arrested for criminal libel against President Adams. ${ }^{352}$ Even Jefferson did not oppose in principle the concept of seditious libel. ${ }^{363}$ Leonard Levy explains that Jefferson accepted "the dominant view of his generation that government could be criminally assaulted merely by the expression of critical opinions that allegedly tended to subvert it by lowering it in the public's esteem." 354 Indeed, when he became President, Jefferson suggested the use of state criminal libel prosecutions against Federalist editors for personal attacks on him. ${ }^{355}$ Although some Republicans would articulate libertarian arguments against the Sedition Act, ${ }^{368}$ Jefferson couched his objections mostly in terms of its interference with the states' prerogatives. ${ }^{357}$

During the congressional debates on the Act, Republicans taunted the Federalists on the necessity for its passage. Representative Nathaniel Macon asked from the floor: "He knew persons might be prosecuted for a libel under the State Governments; but if this power exist in full force at present, what necessity can there be for this bill?"358 And there was something to this: the Sedition Act "did not propose to do more than the states had already done; nor did it alter in any way the timehonored common-law, definition of sedition."358 But it was obvious what the Federalists had in mind by statutorily securing the option of sedition prosecutions in federal courts. They were worried that in Re-

under the 1790 Act, which required showing that the libel "offer[ed] violence" to a foreign minister. At a minimum, Iredell's instructions may be seen as a common-law process of defining a crime from a vague statute. While the records do not indicate the subsequent proceedings, Greenleaf was indicted a second time in April 1797 for libelling the British Consul General; he was found guilty after a trial conducted by Chief Justice Ellsworth and Judge Robert Troup. See J. GoeBEL, supra note 59, at 629. For the 1797 prosecution, the 1790 statute would not have applied since a consul was involved, and the 1790 Act had been construed by the Attorney General to apply only to foreign ministers and ambassadors. See 1 Officral OpINIONS OF THE AtTORNEYs General of the United States 41-43 (B. Hall ed. 1857).

352 See D. StewarT, supra note 158, at 467. This arrest may have led to the introduction of the Sediton bill in its final form. See id. Justice Chase's opinion in Worrall "was cited almost immediately as a precedent by counsel" for Bache; this was to no avail as the judge in the case was Richard Peters, who had split with Chase in Worrall. $1 \mathrm{~J}$. GoEBEL, supra note 59, at 632 .

${ }^{353}$ L. LEVY, supra note 40 , at 46 . One example is the Republican attempt to prosecute William Cobbett. See supra notes 313-14 and accompanying text.

3s4 L. LEVY, supra note 40 , at 46.

sss See N. SCHACHNER, supra note 162 , at 464.

${ }^{358}$ See L. LEVY, supra note 40 , at 55.

387 See id. at 56. Many states had statutes "affirming the common-law doctrine of seditious and malicious libels-and this in spite of the strict injunction written into their constitutions providing for the freedom of the press." J. Miller, GRISIS IN FREEDOM: The Alien and Sedition Acts 80 (1951).

ss8 8 AnNals of Cong. 2106 (1798).

$358 \mathrm{~J}$. Miller, supra note 357 , at 81 . 
publican dominated areas it would be unlikely for actions to be brought under state law. With the existing controversy over federal commonlaw crimes, a situation aggravated by Justice Chase's denial of the jurisdiction, ${ }^{360}$ the Federalists insisted upon providing a federal statutory basis for seditious libel. In one way they were successful at the endeavor since the Federalist judiciary-particularly Justice Chase-took an active part in the enforcement of the Act. ${ }^{361}$ Nevertheless, federal common-law jurisdiction did not fade from the picture. On the contrary, the debates, both on the passage of the Act and then during the aborted attempt to renew it, riveted attention on the matter.

The Sedition Act issue, at least to the extent that the common-law question became embroiled in it, was dominated by a political clash over federalism principles. Republicans did charge that the prosecutions would be prejudicial to the accused: defendants would not be tried in their vicinity; Federalist marshals would hand-pick juries; judges would be appointees of the same Administration that the defendants were said to have acted against. ${ }^{362}$ These arguments notwithstanding, the opposition legislators and the Republican press would persistently return to the question of states' rights.

To justify the Sedition Act, Federalists advanced what may have appeared to be an ingenious argument. Federal courts, they said, already had jurisdiction over common-law sedition. ${ }^{363}$ What the Act accomplished was a liberalization of the harsh common-law rule of seditious libel. Under the statute, intent had to be proved, whereas at common law the mere act of publication was enough to convict. At common law punishment was discretionary with the court, whereas the Act set a definite term. Unlike the common law, truth could be offered in defense. Juries would decide both law and fact, again a departure

soo See discussion of Worrall, supra, text accompanying notes 315-40.

${ }^{361}$ See 1 C. Haines, The Role of the Supreme Court in American GovERNMENT AND POLITICS, 1789-1835, at 160 (1944); infra text accompanying notes 394-413.

382 See 8 AnNals of Cong. 2163-64 (1798) (statement of Rep. Gallatin); J. SMITH, supra note 161, at 140-41; D. STEWART, supra note 158, at 468-70.

ses See J. SMITH, supra note 161, at 139. Robert G. Harper, an erstwhile Republican who was a rising star among Federalists, qualified his position more carefully than many in the Federalist party. He thought "that there was no common-law jurisdiction in the Courts of the United States; but he believed the common-law doctrines of libels as applicable to the Government of the United States as to any other Government." 8 ANNALS OF CoNG. 2141 (1798). In later debates, however, Harper said that "he never had a doubt" that "the offense of libelling the Government was punishable in the United States without the aid of a statute." 10 ANNALS OF CoNG. 414 (1800). As a species of common law, "which our forefathers brought with them," he continued, the offense "arises under the Constitution, and in that view the judiciary power can punish libels against the Government of the United States." Id. at 414-15. 
from common law. ${ }^{364}$

Phrased in these terms, the Federalist justification for the Act immediately precipitated controversy over whether the common law was at all applicable to the federal government in the absence of statutory reception. ${ }^{366}$ Federalists took various tacks on this issue, as did their opponents-none of whom, as Julius Goebel has remarked, "resembl[ed] a searching inquiry on a professional level into what was the constitutional warrant for judicial dependence upon the common law."368

Throughout the debates on the Act, Federalists labored the Revolutionary argument that the common law was the birthright of the colonists. As to what they meant by common law, Representative Samuel W. Dana declared-during the later debates on continuing the Act-it wass "[t]hat common. law which most undoubtedly secured to every indi- . vidual its most endeared rights, and afforded security against every species of legal oppression . . . ."367 Without the common law, Representative James A. Bayard proclaimed, "there is no law," since virtually all statutes and the Constitution itself were predicated upon its existence. ${ }^{368} \mathrm{He}$ continued:

If we are governed without law, it is despotism, whether government is by the will of one or many. Were we left to the will of courts we should be in a state of uncertainty; we should be liable to suffer from caprice, vice, folly, and every weakness. The existence of the common law is of immense importance; without it, the Constitution would be a mere skeleton, devoid of sinews and nerves, and incapable of motion. ${ }^{368}$

Federalists pointed to the numerous provisions in the Constitution and national statutes containing terms that presumed reference to accepted

sot See L. LeVy, supra note 40, at 50-51; J. MrLleR, supra note 357, at 81-82. See also 10 AnNals of CoNG. 950 (1801) (statement of Rep. Bayard) (claiming that the Sedition law. "limits and softens the penalties in cases of libels"); $i d$. at 921 (statement of Rep. Griswold) (explaining that the defense of truth was not available at common law); id. at 940 (statement of Rep. Harper) (stating that the Sedition Act was more favorable for the press because it did not leave the punishment to the discretion of the court); 9 Annals of Cong. 2989 (1799) (Report of House Select Committee).

sos See D. STEWART, supra note 158, at 470.

366 J. GoEBEL, supra note 59 , at 654 .

367 10 ANNALS OF CoNG. 924 (1801); see also 8 ANNALs of Cong. 2146 (1798) (statement of Rep. Otis) (characterizing English common law as "birthright" of Americans).

36810 AnNals of Cong. 949 (1801).

seg Id. 
common-law meanings. ${ }^{\text {970 }}$

Republicans conceded part of this argument, which they were obliged to do. It "had never been denied," responded the House minority leader, Representative Albert Gallatin, "that the common law is in some measure the law of the land." "confound[ing] two very distinct ideas-the principles of the common law, and the jurisdiction over cases arising under it." sisted that there was no common-law jurisdiction. ${ }^{373}$ But in explaining this point, the Congressman diverted the argument to a peripheral issue. Gallatin asserted that there could be no national common law because " $[t]$ he common law of Great Britain received in each colony, had in every one received modifications arising from their situation ... and now each State had a common law, in its general principles the same, but in many particulars differing from each other." 374 The Constitution could not have adopted the common law, Representative John Nicholas continued, when it "is so various [among the States], that ... no man perfectly knew it at the time ....".s75

That the common law differed in content amongst the states was irrelevant, and Federalists had no trouble rebutting the contention. Representative Harrison G. Otis responded with the obvious:

We mean not the law of England in its full extent. We know that a great part of that law does not apply to the nature of our Government or the circumstances of our country. But we mean so much of that law as, being applicable to the circumstances of this people, has been adopted into practice by constant and immemorial usage. ${ }^{378}$

To illustrate, he noted that every state had unquestioned authority to punish crimes. This was

inherent in the people of every State, and had never been relinquished by any of the United States. It was a principle of common law essential to the preservation of social order and of every Government under Heaven. It was the basis of the present Constitution; a birthright to which we should

370 See, e.g., id. at 949-50 (statement of Rep. Dana); id. at 411-12 (1800) (statement of Rep. Bayard); id. at 417-18 (statement of Rep. Otis); id. at 420-21 (statement of Rep. Dana).

s71 Id. at 951 (1801).

372 8 ANNALs OF Cong. 2157 (1798) (statement of Rep. Albert Gallatin).

s7s See id. at 2137.

374 Id.

s75 8 ANnALS OF Cong. 2141 (1798).

376 10 ANNAlS of ConG. 418 (1800). 
cling as a blessing and a privilege, and not abjure as a curse. ${ }^{377}$

Federalists asked what could be the objection to the courts of the United States using the same process of common-law decisionmaking as was employed "in the courts of the different States, where they love the common law?"378 And that pinpointed the source of the division between the two camps. While Federalists were confident that commonlaw decisionmaking was an attribute of every government, Republicans adamantly held that the federal government had no such characteristic. The common law "was a complete system," Representative Nicholas reminded his Federalist opponents, which was designed "for the management of all the affairs of a country. It regulated estate, punished all crimes, and, in short, went to all things for which laws are necessary. It might be more properly considered as the measure of the powers left with the States."379 To allow federal courts this authority "was clearly the same," declared Representative Gallatin, "as setting aside at one stroke all the restrictions and limitations of power as expressed in the Constitution."

Republicans insisted on being told which provision in the Constitution gave the federal courts such authority. Surely Congress had no ability to adopt this "complete system" of laws, which would displace state power entirely. Neither could a national common law be justified as "necessary and proper" to constituting the judiciary-unless it was "intended to give them a power not necessary to their declared powers." ${ }^{\text {"31 }}$ Representative Gallatin had earlier denied that article III contained any language that might support a claim that the federal judiciary, even with the assistance of enabling legislation, could act as common-law courts:

[F]or the judicial authority of those courts is, by the Constitution, declared to extend to cases of Admiralty, or affecting public Ministers; to suits between States, citizens of different States, or foreigners, and to cases arising under the Constitution, laws, and treaties, made under the authority of that Constitution; excluding, therefore, cases not arising under either-cases arising under the common law. ${ }^{382}$

377 Id.

s78 Id. at 949 (1801) (statement of Rep. Bayard).

3709 ANNALS OF CONG. 3012 (1799) (statement of Rep. Nicholas).

s80 10 ANNALS OF CoNG. 413 (1800) (omitted portions of this quote appear supra in text accompanying note 380 ).

s81 9 ANNALS OF CONG. 3012 (1799) (statement of Rep. Nicholas).

3828 ANNALS OF CoNG. 2157 (1798) (emphasis added). 
Gallatin somewhat distorted the text of article III to serve his purpose. $^{383}$ More importantly, in presenting the issue, he revealed the real sources of contention. "The question was not," Gallatin urged, "whether the Courts of the United States had, without this law, the power to punish libels, but whether, supposing they had not the power, Congress had that of giving them this jurisdiction-whether Congress were vested by the Constitution with the authority of passing this bill?" 384 There were actually two interrelated issues here, and Gallatin elaborated on these in a speech less than two years later in which he argued against extending the Act:

[I]f it was intended to say that certain species of offences, which had been recognised as offences by the common law (perhaps) of Great Britain, were within the jurisdiction of the judiciary of the United States, merely because they were offences at common law, it was ... . giving to the judiciary a legislative power of adopting certain laws not enacted by Congress as the law of the land. Indeed it was giving a farther power: Congress had no power to legislate on any subject which was not specially granted to them by the Constitution; but, if the other doctrine was true, the judiciary could decide on subjects upon which Congress could not legislate. ${ }^{385}$

To modern readers, Gallatin's remarks may appear to blend arguments over federalism with those of separation of powers. Republicans were bothered by the judiciary's role in defining crimes; they were the ones who had experienced the effects of these prosecutions. Yet the power of state courts to convict for seditious libel under common-law authority was conceded by the Republicans, albeit grudgingly at times. $^{386}$ The prime source of dispute was not the scope of judicial

sss Article III reads: "The judicial Power shall extend to all Cases, in Law and Equity, arising under this Constitution, the Laws of the United States, and Treaties made, or which shall be made, under their Authority . . . " U.S. CoNST. art. III, \& 2 , ch. 1. The use of "made" would seem to be a reference to treaties, not to laws. Few, however, would want to stake a constitutional argument on a comma placement.

s84 8 AnNals OF CONG. 2157-58 (1798).

s8s 10 AnNals of CoNG. 413 (1800) (The omitted portions of this quote appear in text accompanying note 360 .).

${ }^{380}$ See supra text accompanying note 358 (statement of Rep. Macon). Some Republicans, such as Representative Thomas Claiborne, claimed that "the doctrine of libels was very unsettled in this country. Prosecutions of this kind have very rarely happened ... " 8 ANNals of Cong. 2135 (1798). Representative Robert G. Harper responded that the law was well settled, and noted that "[h]e had himself been witness to four or five trials of this kind in the State from which he came, and could not believe there could remain a doubt as to the power in such cases." Id. at 2136. During 
power, but rather the powers of the federal government itself.

Federalists contended that the federal judiciary was akin to state judiciaries. "No State has enacted statutes for the punishment of all crimes which may be committed,"s87 observed Representative Otis in the 1798 Sedition Act debates. Instead, "in every State . . . there was a Superior Court which claimed cognizance of all offences against good morals, and which restrained misdemeanors and opposition to the constituted authorities, under the sanction merely of the common law." Americans, he continued, were "habituated" to the common law when they adopted their national government, and thus "it will be natural to conclude that, in forming the Constitution, they kept in view the model of the common law, and that a safe recourse may be had to it in all cases that would otherwise be doubtful." 389 With regard to federal jurisdiction, Otis maintained that "one great end of this compact . . - is the establishment of justice," which he argued was the purpose of article III. ${ }^{390}$ Otis then committed himself:

Justice, if the common law ideas of it are rejected, is susceptible of various constructions, but agreeably to the principles of that law, it affords redress for every injury, and provides a punishment for every crime that threatens to disturb the lawful operations of Government. Again, what is intended by 'cases at law and equity arising under the Constitution,' as distinguished from cases 'arising under the laws of the United States?' What other law can be contemplated but common law; what sort of equity but that legal discretion which has been exercised in England from time immemorial ... ? ?891

Other Federalist leaders were just as candid in claiming that common-law jurisdiction existed by virtue of of the judicial powers encom-

the subsequent debates over continuing the Sedition Act, Representative Otis singled out a favorite Republican example of a notorious libel prosecution to point out that it had been held "upon that good old wholesome common law," and not the Sedition Act. See 10 Annals of Cong. 955 (1801). For examples of state libel prosecutions at this time, see N. SCHACHNER, supra note 162, at 479, 483; Anderson, Contemporary Opinion of the Virginia and Kentucky Resolutions, 5 AM. HIST. REv. 45, 61-63 (1899).

3878 ANNALS OF CONGRESS 2146 (1798).

s8s $I d$.

389 Id.

890 Id.

s01 Id. at 2146-47. Otis reminded his listeners and readers of the many federal common-law prosecutions, and noted the clause in the statutory admiralty jurisdiction "saving to suitors in all cases the right of a common law remedy, where the common law was competent to give it." "Id. (quoting The Judiciary Act of 1789, 1 Stat. 73, 77, ch. $20, \S 9(\mathrm{a}))$. 
passed by the Constitution. ${ }^{382}$ This reading of the Constitution is what prompted the remark from Representative Nicholas that the common law was a "complete system." "39s To the Republicans, their opponents were claiming a federal establishment of vast powers, far exceeding those enumerated in article $\mathrm{I}$.

\section{The Federal Judiciary and the Common Law During the Sedition Act Controversy}

One significant outgrowth of the Sedition Act was the consistent assertion by federal judges of "competent authority to pass upon [an Act of Congress], and to decide whether it be const[itutional] or not." Of course, the Act cleared this hurdle; as Justice Paterson said, "[I]t [is] well known, that the circuit courts of the U[nited] States have uniformly declared, that Congress were authorized to pass the law in question ... . ."395 Federal judges went beyond these pronouncements; they helped lead the charge in enforcing the Act, convinced that Republicans were "by arts of sophistry . . . inflaming the passions of weak minds, delud[ing] many into opinions the most dangerous, and conduct[ing] them to actions the most criminal." 396 Perhaps no other series of opinions better reflects the underlying social values of many on the federal bench. Consider this grand jury charge by Justice Paterson:

Seditious persons are common disturbers of public repose, and pests to society; they are bad men and worse citizens. The apostolic rule to mind our own business, and study to be quiet is an excellent guide in social life. Let us seek peace and be obedient to the laws; let us fear God, respect our government, and honor the constituted authorities of our country. ${ }^{387}$

A number of the Federalists' arguments that appeared in the con-

392 See, e.g., 10 Annals of Cong. 411 (1800) (statement of Rep. Bayard) ("He had always been of opinion ... that the common law existed under the Constitution of the United States ... . [A]ll judges united in [this] opinion with the exception of one."); see also J. Miller, The Federalist ERA 232 (1960) (explaining that in the Federalists' eyes, the Sedition Act was constitutional because the Constitution had "endowed the national government with cognizance over all cases arising under the common law").

sos 9 Annals of Cong. 3012 (1799).

sor Opinion of Justice William Paterson, W. Paterson, supra note 243, at 543.

sos $I d$.

sos Charge to the Grand Jury for the District of Pennsylvania (Apr. 11, 1799), supra note 349. For an examination of the participation of federal judges in enforcing the Sedition Act, see supra notes 168-69 \& 361 and accompanying text.

${ }^{s 97}$ Grand Jury Charge (n.d., n.p.), W. Paterson, supra note 347. 
gressional debates can also be found in the judicial writings of this period. Justice Iredell, for example, quoted extensively from Blackstone during a grand jury charge to justify his conclusion that the first amendment prohibited only prior restraints. A government must through criminal libel prosecutions, Iredell asserted, "censure the licentiousness . . . to maintain the liberty of the press." 388 Both Iredell and Paterson echoed the sentiment heard in Congress that the Sedition Act was far less restrictive of the press than was the common law. ${ }^{398}$ This line of defense was meant not only as an interpretation of the first amendment; it also introduced the question of whether the federal courts had jurisdiction over common-law libel prosecutions.

In what appears to have been the draft of an opinion, Justice Paterson addressed the issue of common-law libel actions in federal court:

I have no doubt of its extension. Throughout the constit[utio]n references are made to it. . . .

The common law extends to every state. Our ancestors brought it over with them as their birthright. It is somewhat remarkable, that the common law should extend to the states individually, and yet not to the states collectively, or in the aggregate. The const[itutio]n of the U[nited] States was intended ... to confirm, preserve, and perpetuate these rights .... The result is, that the const[itutio]n is predicated upon the com[mon] law; it assumes it as an existing rule, and is built upon it as such. ${ }^{400}$

So far this quote may seem compatible with the more modest proposition that the Constitution must be interpreted in light of common-law usage. This was part of what Paterson and others were maintaining, but it was only the foundation for a quite larger claim.

Paterson explicitly endorsed common-law prosecutions in federal courts, saying that "[t]he principle of self defense and preservation, which pervades nations, as well as individuals, renders the punishment of offences an indispensible requisite in every government."401 For constitutional authorization of the assumption of jurisdiction, Paterson relied upon article III:

s98 Charge to the Grand Jury for the District of Pennsylvania (Apr. 11, 1799), supra note 349 (quoting $4 \mathrm{~W}$. Blackstone, Commentaries, supra note 254, at 151).

398 See id.; W. Paterson, supra note 243, at 535-37.

$400 \mathrm{~W}$. Paterson, supra note 243, at 533-35.

401 Id. at 565. 
The judicial power shall extend to all cases in law and equity, \&c. All cases in law and equity have a clear and definite meaning, well understood through our whole country. All cases at law mean all cases at common law arising under the const[itutio]n.-The common law is the unwritten law, is recognized in and pervades every state of the Union. To calumniate the governm[en]t or oppose lawful acts is an offence at com[mon] law. ${ }^{402}$

During the congressional debates, this type of contention had drawn the severest of Republican denunciations-that Federalists were paving the way for a consolidated national government. Paterson did not shirk from the assault:

The const[itutio]n of the U[nited] States is sui generis; it is a mixed thing, partly consolidated \& partly federal, though in its prominent features, it has more of the former than of the latter. It must be agreed, that the United States, under the existing const[itutio]n, form a complete, sovereign, and independent nation, to which the rights of sovereigns and the law of nations attach .... The enumeration [of powers in the Constitution] is complete, and embraces all the great objects of national association. ${ }^{403}$

Nor were Paterson's comments isolated sentiments. Chief Justice Ellsworth used much the same language before a 1799 grand jury, in a charge that was widely reprinted throughout the country:

An offence consists in transgressing the sovereign will ... . Conduct therefore, clearly destructive of a government, or its powers, which the people have ordained to exist, must be criminal. It is not necessary to particularize the facts falling within this description, because they are readily perceived, and are ascertained by known and established rules; I mean the maxims and principles of the common law of our land. This law, as brought from the country of our ancestors . . . was the law of every part of the union at the formation of the national compact; and did, of course, attach upon or apply to it, for the purposes of exposition and enforcement. It is true, that the parties acting in their sovereign capacity, might have discontinued that law . . . but that they intended a discontinuance so contrary to usage in 
similar cases, and so pregnant with mischief, is certainly not to be presumed; and it is a supposition irreconcilable with those frequent references in the constitution to the common law, as a living code. ${ }^{404}$

Ellsworth was presented with the opportunity to apply this philosophy in a case that same year, United States $v$. Williams. ${ }^{405}$ This was not a sedition action, but an indictment "on one of the articles of the British treaty" for various acts of hostility against England, which included serving on a French warship and privateering. ${ }^{406}$ Williams defended on the ground that prior to these actions, to which he admitted,

406 Charge to the Grand Jury for the District of South Carolina (May 15, 1799), reprinted in Claypoole's American Daily Advertiser (Philadelphia), May 31, 1799; also reprinted in Virginia Argus (Richmond), Aug. 9, 1799; City Gazette (Charleston), July 15, 1799; Columbian Centinel (Boston), July 7, 1799; Newport Mercury (Newport, R.I.), June 18, 1799; Farmer's Museum or Lay Preacher's Gazette (Walpole, N.H.), June 17, 1799; Independent Chronicle (Boston), June 13, 1799; Federal Gazette (Baltimore), June 10, 1799; American Daily Advertiser (Baltimore), June 5, 1799; The Philadelphia Gazette, June 4, 1799; Daily Advertiser (New York), May 29, 1799.

40529 F. Cas. 1330 (C.C.D. Conn. 1799) (No. 17,708). Ellsworth sat with Judge Richard Law.

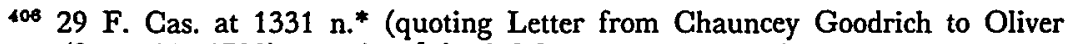
Wolcott (Sept. 28, 1799), reprinted in 2 MEMOIRS OF THE ADMINISTRATIONS OF Washington and Adams 266 (G. Gibbs ed., New York 1846)). In the Trial of William Butler for Piracy 10-11 (1813) [original pamphlet in Harvard Law School Library; copy on file with the University of Pennsylvania Law Review], a decision probably authored by Justice Johnson, it was "suppose[d]" that Williams had been "punishable under the act of June "94," inasmuch as he could not "think that the learned Judge [Ellsworth] would have referred this question to the Common Law of Great Britain, instead of placing it on doctrines of universal law." The author obviously did not have an accurate report of the case, a fact he conceded. See id. at 10. Under the statute mentioned, it was a high misdemeanor for a person "within the territory or jurisdiction of the United States [to] enlist . . . in the service of any foreign prince or state." Act of June 5, 1794, ch. 50, $\S 2,1$ Stat. 381, 383. This statute could not have reached Williams, who was charged in the indictment with accepting a commission from France at Guadaloupe, "without the jurisdiction of any particular state." Williams, 29 F. Cas. at 1330 . The only other way that Williams could have been indicted under the statute would have been to show that he had "go[ne] beyond the limits or jurisdiction of the United States with intent to be enlisted in the service" of another country. Act of June 5,1794, ch. 50, $\S 2,1$ Stat. 381, 383. Not only was the indictment not phrased in these terms, but also this statute was applicable to "any person," not merely citizens. The sole issue in the case was whether Williams was an American citizen at the time of enlistment, a point necessary to establish if the crime were based on the theory used in Henfield. As in Henfield, the indictment avers that Williams was acting against England, "contrary to . . the treaty of amity, commerce, and navigation then existing between Great Britain and the said United States." 29 F. Cas. at 1330. These allegations were irrelevant to a prosecution under the statute mentioned by Johnson. Indeed, Williams' only objection to jurisdiction was that he had renounced his American citizenship "before the ratification of the treaty." Id. Similarly, Williams could not have been indicted under $\S 1$ of the June 5th Act because he was not within the jurisdiction of the United States when he acted. 
he had relinquished American citizenship in favor of French status. Justice Ellsworth rejected the legal sufficiency of the expatriation defense:

The common law of this country remains the same as it was before the Revolution. The present question is to be decided by two great principles; one is, that all the members of civil community are bound to each other by compact. The other is, that one of the parties to this compact cannot dissolve it by his own act. ${ }^{107}$

Ellsworth denied that Williams had been granted permission to expatriate, and the defendant was convicted, fined, and imprisoned.

Charles Warren wrote of Williams that "[n]o decision by any Federal Judge had ever aroused so great and widespread resentment."408 Since the case was decided during the undeclared war at sea between France and the United States, it immediately provoked passionate feelings in the popular press. The court was accused of advocating monarchial principles, of resurrecting the principle from feudal times that one cannot expatriate, and of making Americans once again subjects of Great Britain by applying its common law..$^{\mathbf{1 0}}$

John Marshall saw the matter differently, as he explained to a correspondent in 1800:

Isaac Williams was prosecuted on two separate indictments-the one for privateering under a French commission against the British \& the other for privateering under the same commission against his own countrymen. He was found guilty on both indictments. In the one case he was guilty of an offence against a public treaty of the United States \& in the other of an offence against the United States on the high seas. . . . The defence set up, so far as I understand it, was that by taking a commission in the service of France which was itself a crime, Isaac Williams withdrew himself from the cognizance of our courts by ceasing to be an American citizen. . . .

In the case of Williams the common law was not relied on as giving the court jurisdiction, but came in incidentally as part of the law of a case of which the court had complete and exclusive possession. I do not understand you as ques-

${ }^{407} 29 \mathrm{~F}$. Cas. at 1331.

4081 C. WARREN, supra note 38 , at 161. 161-62.

109 See D. STEWART, supra note 158 , at $151 ; 1$ C. WARREN, supra note 38 , at 
tioning the propriety of thus applying the common law, not of England, but of our own country. ${ }^{410}$

These sentiments, paralleled by those in Ellsworth's opinion in Williams, expanded the inquiry over the scope of federal common-law crimes. No longer was it stated as simply as it was in Henfield, that the United States could develop its own common law to treat those who threatened national peace via the accepted route of nonstatutory prosecutions. Now the matter was put in a much broader fashion: that the principles of the common law were directly applicable to the judiciary of the United States. Marshall might insist that this was the common law "of our own country," but Ellsworth's opinion reflected the obvious-any unwritten law would necessarily use the common law of England as the most important source of reference. Certainly that is what occurred in Williams. This aspect of Williams was seized upon instantly by the opposition and turned into a rhetorical weapon of unlimited possibilities. Peter Du Ponceau would later write about the distortion of the issue: "Thus a sound doctrine by being mixed with a doubtful, and, at any rate, an unpopular principle, made a nation afraid of the common law, which they thought turned their country into a prison and preventing [sic] them from migrating withersoever they pleased."411

The remarks by Marshall, Paterson, and Ellsworth contain a potent ambiguity that pervaded the congressional discussions as well. Albert Gallatin came closest in exposing the problem when he announced that Federalists were confusing "two very distinct ideas," those being "the principles of the common law, and the jurisdiction over cases arising under it."412 Apparently finessing the question, Marshall denied that the common law gave a federal court jurisdiction; it came in "incidentally" to courts already possessing "complete and exclusive" jurisdiction. But what was the source of that jurisdiction? Those Federalists who replied "the Constitution" invited the attacks on the Sedition Act that came out in Congress. Perhaps Marshall and others meant the only other alternative: that Section 11 of the 1789 Judiciary Act had

410 Letter from John Marshall to St. George Tucker (Nov. 27, 1800) [original on file in the manuscript division of the Library of Congress; reproduced in Appendix A to Part Two]. For a discussion of Marshall's position on the question of federal commonlaw crimes, see Appendix B to Part Two.

111 P. Du Ponceau, A Dissertation on the Nature and Extent of The Jurisdiction of the Courts of THE United States 93 (Philadelphia 1824). An equally troublesome aspect of Ellsworth's position was the fact that the British used it as a justification for the impressment of American sailors. See 1 C. WARREN, supra note 38 , at 162 .

4128 Annals of Cong. 2157 (1798). 
given federal courts authority over federal common-law crimes by virtue of its grant of "exclusive cognizance of all crimes and offenses cognizable under the authority of the United States." 113 If so, that interpretation turned section 11 into an open-ended provision for commonlaw criminal jurisdiction, constrained only by the judges' discretion in deciding what was "the common law ... of our own country." Republicans were scarcely willing to entrust that responsibility to the likes of federal judges they already knew, much less the future Chief Justice.

\section{Pushed to Extremes: Jefferson and Madison on the Common Law}

It would be an understatement to characterize the Republican reaction to the Federalist position on national judicial power that emerged in the late 1790's as vehement or caustic. One consequence of the enactment of the Alien and Sedition Acts was the Virginia and Kentucky Resolutions, which in frank terms declared the Union a compact among states that gave the federal government only limited powers, "and that, in case of a deliberate, palpable, and dangerous exercise of other powers, not granted by the said compact, the states . . . are in duty bound, to interpose, for arresting the progress of the evil ...."414 Virginia's version insisted that the Alien and Sedition Acts were beyond the power delegated to the federal government. ${ }^{415}$ In an accompanying document, the House of Delegates advanced the argument another step, contending that if these acts were constitutional, "Congress will be endowed with a power of legislation in all cases whatsoever, and the states will be stripped of every right reserved, by the concurrent claims of a paramount legislature."418 The House went

413 See supra note 59 and accompanying text.

414 Virginia Resolution of 1798, reprinted in 4 Elliot's Debates, supra note 138, at 528. The Kentucky Resolution also declared that the Constitution was a "compact," the terms of which "each party has an equal right to judge for itself, as well of infractions as of the mode and measure of redress." Kentucky Resolutions of 1798 and 1799, reprinted in 4 Elliot's DeBATES, supra note 138, at 540. It went on to announce that the Alien and Sedition Acts were "altogether void, and of no force." Id. A year later, after Virginia remained the sole state willing to pass a similar resolution, Kentucky passed a second resolution, protesting " $[t]$ hat the several states who formed that instrument [the Constitution], being sovereign and independent, have the unquestionable right to judge of the infraction: and, That a nullification, by those sovereignties, of all unauthorized acts done under color of that instrument, is the rightful remedy ...."Reprinted in 4 ELLIOT's DeBates, supra note 138, at 545.

416 Extracts from the Address to the People, reprinted in 4 Elliot's Debates, supra note 138 , at 530 .

416 Id. at 531 . 
on to a litany of complaints aimed at the two Federalist Administrations, touching on familiar topics: economic regulation, "which keep[s] a host of commercial and wealthy individuals imbodied, and obedient to the mandates of the treasury," "17 military appropriations for a permanent army and navy charged with "punishing imaginary insurrections," "418 "swarms" of federal officers "act[ing] as spies over the free exercise of human reason," objections were the obligatory blasts at consolidation and monarchism.

In addition to drafting the Virginia Resolution, Madison prepared a report for the House of Delegates that linked the Federalist claims in support of the Alien and Sedition Acts with the federal common-law issue. First, Madison observed that "[i]f . . . the common law is established by the Constitution, it follows that no part of the law can be altered by the legislature. . . . [T] he whole code, with all its incongruities, barbarisms, and bloody maxims, would be inviolably saddled on the good people of the United States." common law were rejected, and Congress did have the power to alter laws, "it then follows that the authority of Congress is coextensive with the objects of common law . . . . Congress would, therefore, be no longer under the limitation marked out in the Constitution."421 Moreover, Madison charged the Federalists with attempting to incorporate "part of the unwritten law of England" into the Constitution. ${ }^{\text {422 Fi- }}$ nally, the report warned that "whether the common law be admitted as of legal or of constitutional obligation, it would confer on the judicial department a discretion little short of a legislative power." ${ }^{2423}$

The first of Madison's points-that the common law would not be modifiable by Congress if it were part of the Constitution-seems hard to take seriously, but it was frequently made at the time. ${ }^{\mathbf{2 4}}$ This argument illustrates the manner in which the Republicans had strategically transformed the Federalist position. By insisting that their opponents were actually incorporating the corpus of English common law, they powerfully manipulated the symbols of the controversy. In one bold stroke they drew upon deep anxieties about English domination, made

417 Id.

418 Id.

110 Id.

120 Madison's Report on the Virginia Resolutions (1800), reprinted in 4 ELLIOT'S DeBATES, supra note 138, at 565.

121 Id. at 566.

122 Id.

423 Id.

434 See, e.g., 8 Annals of Cong. 2142 (1798) (statement of Rep. Nicholas) ("If gentlemen say it is adopted by the Constitution, it must remain unchangeable . : . ."). 
plausible the claim that Federalists were monarchists, and traded on fears that the English common law was far too antiquated, intricate, and technical for republican sensibilities. ${ }^{425}$

One suspects that these were rhetorical flourishes to garnish the main item of complaint-that the assertion of common-law powers by federal courts was tantamount to claiming that the United States was a consolidated national government. Jefferson reiterated this theme in 1800 , warning that if the Federalist position were accepted, then the general government would be "possesse[d] . . . of all the powers of the state governments, and reduce[] . . . us to a single consolidated government." ${ }^{\text {\$26 }}$ Considering the tameness of modern discussions about federal common law, and the total lack of public controversy over the subject, it is difficult to conceive of Jefferson writing the following:

[I]f the principle were to prevail, of a common law being in force in the US, . . . it would become the most corrupt government on the earth. You have seen the practises by which the public servants have been able to cover their conduct, or, where that could not be done, delusions by which they have varnished it for the eye of their constituents. What an augmentation of the field for jobbing, speculating, plundering, office-building $\&$ office-hunting would be produced by an assumption of all the state powers into the hands of the general government. ${ }^{427}$

For Jefferson and other Republicans, the issue was a part of a much larger scheme. With respect to the common law, he had "no doubt [that Federalists had] decided to cram it down our throats," and that they were attempting to "accomplish a monarchy peaceably, or force a resistance [that] with the aid of any army may end in monarchy." 28 Jefferson wrote this in October of 1799, when "[t]he late misfortunes of France would probably render the consolidationers more enterprising and more intolerant than ever."429 It was in February of the same year that Hamilton, alarmed at the mood in Virginia and Kentucky, had proposed raising a sizeable army. ${ }^{430}$ Along with these proposals, Hamilton and other Federalists were planning a significant

${ }^{425}$ See 2 A. Chroust, supra note 292, at 56-57.

128 Letter from Thomas Jefferson to Gideon Granger (Aug. 13, 1800), reprinted in 9 The Works of Thomas Jefrerson 139 (P. Ford ed. 1905).

${ }_{127}$ Id. at $139-40$.

128 Letter from Thomas Jefferson to Charles Pinckney (Oct. 29, 1799), reprinted in 9 The Works of Thomas JefFerson 87 (P. Ford ed. 1905).

420 Id. at 88.

430 See Turner, supra note 160 , at 9. 
expansion in the size and scope of the federal judiciary through a legislative initiative that would become the 1801 Judiciary Act. ${ }^{431}$ Jefferson expressed his concern over the Federalist plans in a letter to Edmund Randolph that August:

Of all the doctrines which have ever been broached by the federal government, the novel one, of the common law being in force \& cognizable as an existing law in their courts, is to me the most formidable. All their other assumptions of un-given powers have been in the detail. The bank law, the treaty doctrine, the sedition act, alien act, the undertaking to change the state laws of evidence in the state courts by certain parts of the stamp act, \&c., \&c., have been solitary, unconsequential, timid things, in comparison with the audacious, barefaced and sweeping pretension to a system of law for the $U S$, without the adoption of their legislature, and so infinitely beyond their power to adopt. If this assumption be yielded to, the state courts may be shut up, as there will then be nothing to hinder citizens of the same state suing each other in the federal courts in every case, as on a bond for instance, because the common law obliges payment of it, \& the common law they say is their law. ${ }^{432}$

There is more than a bit of irony in this correspondence between two men who had once played key roles in the prosecution of Gideon Henfield. ${ }^{43}$ Randolph observed in a letter to Madison at this time that

431 Ch. 4, 2 Stat. 89, repealed by Act of March 8, 1802, ch. 8, 2 Stat. 132. For a discussion of the politics of the 1801 Judiciary Act, see infra text accompanying notes 454-76.

432 Letter from Thomas Jefferson to Edmund Randolph, (Aug. 18, 1799), reprinted in 9 The Works of Thomas Jefrerson 73 (P. Ford ed. 1905).

43s For a discussion of Henfield, see supra text accompanying notes 221-43. Randolph offered an explanation for his earlier theory in that case, noting that the "general question" of common-law jurisdiction "never came into consideration." Letter from Edmund Randolph to James Madison (1799), reprinted in M. Conway, OMITTED Ghapters of History Disclosed in the Life and Papers of EdMund RaNDOLPH 185 (2d ed. 1888) (1st ed. New York 1887). Rather, the basis for the indictment, Randolph explained, was Henfield's treaty violation considered in light of Section 34 of the 1789 Judiciary Act, ch. 20, 1 Stat. 73, 92 (Sept. 24, 1798) (current version at 28 U.S.C. $\$ 1652$ (1982)), which made state law the rule of decision: "[T]he laws of Pennsylvania, within those boundaries the offence was committed, comprehending the common law, would aid the treaty .... [N]amely, that when a statute forbids a thing to be done, without annexing a penalty, the common law makes it indictable and punishable, as a misdemeanor." Letter from Edmund Randolph to James Madison (1799), supra, at 185. Randolph had, however, signed the government's brief in Henfield, in which it was argued that the defendant's conduct constituted "an offence against our own country, at common law, because the right of war is vested in the government only." Henfield, 11 F. Cas. at 1117. These were not "specu- 
the trial had occurred "when party had not taken deep root, and consequences to one or the other side were not foreseen."434 This comment betrays more than the obvious fact that the whole controversy had become associated with the fortunes of partisan players. Looking back over the previous decade, an observer could appreciate how the dispute had been recharacterized, with the constitutional argument emerging ever more sharply as the political contest matured..35

Jefferson would soon occupy the highest office, and his constitutional views, as we have seen, ${ }^{436}$ would require some substantial alterations. The constitutional issues of this period must be understood in terms of the political atmosphere in which the competing interpretations of the Constitution arose. An additional chapter in the pre-Hudson story needs to be added to complete our outline of the essential political forces that shaped the form in which the issue about the common law was presented. This was the short-lived-still-born would be more accurate-1801 Judiciary Act. ${ }^{437}$

\section{Federal Common Law and the Judiciary Act of 1801}

A long-standing assumption about the 1801 Judiciary Act has

lations of the closet," since "we see them carried into effect in England in affirmation of national common law, i.e. the law of nations." Id. In response to the defense's claim that there was a lack of precedent in support of the action, the prosecution had said: "The first answer is, that it is demonstrated that the law of nations is part of the law of the land. The second answer is, that in numerous other instances, enumerated by Blackstone, the law of nations is enforced by the judiciary." Id. 185.

434 Letter from Edmund Randolph to James Madison (1799), supra note 433, at

435 Scholars of dispute resolutions have characterized the general pattern exhibited by such controversies:

[L]anguage is used as a vehicle for transformation .... To expand a dispute ... is to change the perspective from which the third party would ordinarily view the act, person, or relationship involved in the dispute by placing it in a class of objects from which it would normally be distinguished. This is a political process. Individuals and groups have vested interests in particular definitions of persons and events; changes in definition tend to meet with resistance, and thus require some basis of support if they are to succeed (e.g., linkage to a relevant public with some political or economic power). It is a linguistic process in that changes in perspective and definition involve applying new labels to familiar persons and events. These new labels act as 'a catalyst in the shaping of perception .... [P]eople potentially see an issue in several alternative lights, and the language form itself evokes some of the potentialities....?

Mather \& Yngvesson, Language, Audience and the Transformation of Disputes, 15 Law \& Soc. Rev. 775, 798-99 (1980) (quoting M. Edelman, Politics As SymBolic Action: Mass Arousal AND Quiescence 68 (1971)) (emphasis added by Mather \& Yngvesson).

438 See supra text accompanying notes $105-10$ \& 130-32.

437 Ch. 4, 2 Stat. 89, repealed by Act of March 8, 1802, ch. 8, § 1, 2 Stat. 132. 
been that it represented a "pure case of a political intrigue, of a defeated party striving to retain some semblance of power by intrenching itself in the Judiciary." 488 Republicans charged that Federalists had attempted to "entrench themselves in the event of an unsuccessful issue in the election, and continue[d] to support those favorite principles of irresponsibility which they could never consent to abandon."439 A number of new offices were created, including sixteen judgeships with lifetime tenure, and positions for clerks, attorneys, and marshalls to augment the expanded judicial system. ${ }^{\mathbf{4 0}}$

Republicans paid less attention to the provisions enhancing federal subject matter jurisdiction, which effectively gave the federal courts virtually the full scope of powers authorized by article III. ${ }^{411}$ Most importantly, these provisions expanded the jurisdiction of federal courts to include "all cases in law or equity, arising under the constitution and laws of the United States, and treaties made, or which shall be made, under their authority; and also . . . all actions, or suits of a civil nature, at common law, or in equity, where the United States shall be plaintiffs or complainants." was not enough, the Act also provided the circuit courts with jurisdiction over "all actions, or suits, matters, or things cognizable by the judicial authority of the United States, under and by virtue of the constitution thereof."

There is no explication in the recorded debates of the jurisdiction for cases "arising under the constitution and laws of the United States," or "cognizable by the judicial authority." Moreover, neither of these clauses appeared in the 1789 Judiciary Act. ${ }^{44}$ These were particularly opaque provisions, although no more so than article III itself. Considering the limited activities of the national government, the immediate utility of "arising under" jurisdiction could not have been significant. But, the statutory grant of "arising under" jurisdiction, coupled with the provision for "all actions . . . cognizable by the judicial authority,"445 suggests that the Federalists had some form of common-law process in mind. On the whole the record provides few clues, certainly

438 Sutherland, Politics and the Supreme Court, 48 AM. L. REv. 390, 394 (1914).

43811 ANNALS of Cong. 581 (1802) (statement of Rep. Giles).

440 See Farrand, The Judiciary Act of 1801, 5 Am. HIST. Rev. 682, 686 (1900).

11 See Shulman \& Jaegerman, Some Jurisdictional Limitations on Federal Procedure, 45 YALE L.J. 393, 394 n.5 (1936).

142 Judiciary Act of 1801, ch. 4, § 11, 2 Stat. 89, 92.

113 Id.

114 See Judiciary Act of 1789, ch. 20, 1 Stat. 73 (Sept. 24, 1798) (codified in scattered sections of 28 U.S.C.).

45 Judiciary Act of 1801 , ch. 4, § 11, 2 Stat. 89, 92. 
not enough to indicate any understanding of what we would call "federal common law." Most likely the Federalists were planning ahead by putting in place a judicial system that possessed all the potential powers authorized by the Constitution. It is clear that the Federalists meant to nationalize judicial activity as much as possible. In addition to expanding the subject matter of federal courts, the 1801 Act failed to contain any provision equivalent to section 34 of the 1789 Act, which had required federal courts to utilize the states' laws "in cases where they apply."

Other parts of the Act also reflected Federalist ambitions. The enforcement of federal criminal laws (including sedition) was made far more effective by expanding federal court jurisdiction and judicial enforcement mechanisms; ${ }^{416}$ tax collections, a nagging problem, were similarly enhanced;47 and federal jurisdiction over the new uniform bankruptcy system was established. ${ }^{48}$ Circuit riding by Supreme Court justices, long a source of complaint, was eliminated, and it was hoped that this measure, together with an increase in the number of federal courts, would encourage suitors to use the federal system. ${ }^{49}$ By allowing Justices more time to consider appeals, proponents of the Act expected it to provide for greater uniformity in the laws administered. ${ }^{\mathbf{4 5 0}}$

Federalists actually had been planning the Act for several years, and they envisioned it as an important aspect of their overall national program. In late 1799 Hamilton wrote to Speaker of the House Jonathan Dayton regarding a proposal the former hád made that was similar to the eventually adopted Act: "This measure is necessary to give efficacy to the laws the execution of which is obstructed by the want of similar organs and by the indisposition of the local Magistrates in some states." $\$ 451$ In claiming the necessity for an efficient program to

116 See Turner, supra note 160 , at $21,31-32$.

417 Id. at 31.

48 Judiciary Act of 1801 , ch. 4, § 12, 1 Stat. 89, 92.

419 See, e.g., 11 AnNals of Cong. 117-18 (1802) (statement of Sen. White); id. at 621-22 (statement of Rep. Bayard). These statements were made during the repeal debates, which contain the most extensive recorded discussion of the Act's purpose.

150 See, e.g., id. at 124 (statement of Sen. Ghipman); id. at 619-20 (statement of Rep. Bayard).

${ }^{481}$ Letter from Alexander Hamilton to Jonathan Dayton (Oct. or Nov. 1799), reprinted in 23 The Papers of Alexander Hammton 601 (H. Syrett ed. 1976). Earlier versions of the 1801 Act had been introduced unsuccessfully in the first session of the Sixth Congress in 1800. See Turner, supra note 160, at 7-8. For an account of these events and earlier proposals to expand the federal judiciary, see id. at 8-14. As Hamilton had suggested to Dayton, the 1800 bill-unlike the 1801 Act-divided the judicial system into 29 small districts, including multiple districts for some states. A purported summary of the bill appeared in the Philadelphia Aurora, Mar. 24, 1800; it 
apply federal laws, Federalists made use of an old slogan: that the judiciary was better suited for such purposes than the other alternative, namely the army. ${ }^{452}$ This argument could not have been too persuasive, since the tensions between the United States and France had lessened by this time, and a powerful military was less justified than in previous years. ${ }^{453}$

When the Federalists suffered defeat in the 1800 elections, they had little time left to take advantage of their congressional majority. The purpose behind the proposal for alterations in the federal judiciary promptly changed, and it became a matter of the Federalists preserving a place in the government to guard against anticipated Republican intrigues. John Rutledge, Jr., then a Congressman from South Carolina, indicated to Hamilton that the Act would "of course greatly widen the basis of government. We shall profit of our short lived majority \& do as much good as we can before the end of this session."

At the same time as Hamilton was advocating a new judicial bill, he was urging the continuance and augmentation of the permanent military establishment, which he hoped to accomplish by raising a million dollars in additional tax revenues. ${ }^{455}$ It was not possible that Republicans would be duped into missing the import of the proposed legislation. They responded to the proposals with all of their usual theories about conspiracies and the insatiable tendencies of humans to grasp for ever more power. Representative Joseph $\mathrm{H}$. Nicholson was particularly colorful in the repeal debates of early 1802:

Man is fond of power, is continually grasping after it, and is

included a list of new federal circuits and districts. (The original bill is located in the Library of Congress.) Republicans immediately saw this as a blatant attempt at consolidation, and they responded with sharp questions: "Which state's civil law should be applied when the [circuit] contained parts of two commonwealths?" D. STEWART, supra note 158, at 456. They also charged that this "might invalidate the elementary principle that parties should be tried in the state where the crime was committed." Id.

${ }^{462}$ At the North Carolina ratification convention, William R. Davie had used the often heard expression:

For my own part, I know but two ways in which the laws can be executed by any government. If there be any other, it is unknown to me. The first mode is coercion by military force, and the second is coercion through the judiciary. . . . [G]oercion by force . . . is so extremely repugnant to the principles of justice and the feelings of a free people, that no man will support it. . . [T] There is no rational way of enforcing the laws but by the instrumentality of the judiciary.

4 Elliot's Debates, supra note 138, at 155.

4ss See Turner, supra note 160 , at 32.

154 Letter from John Rutledge, Jr. to Alexander Hamilton (Jan. 10, 1801), reprinted in 25 The Papers of Alexander Hamilton 309 (H. Syrett ed. 1976).

455 See Letter from Alexander Hamilton to Jonathan Dayton (Oct. or Nov. 1799), supra note 451 , at $602-03$. 
never satisfied . . . But power, when once surrendered to independent rulers, instantly becomes a despot, and arms itself with whips and chains. While the people retain it in their own hands, it exalts the character of a nation, and is at once their pride and their security; if they surrender it to others, it becomes restless and active, until it debases the human character, and enslaves the human mind; it is never satisfied until it finally tramples upon all human rights. ${ }^{458}$

Due to the Republican electoral victory, that party's fears of Federalist consolidation were allayed, and the new court system was never effectively tested. ${ }^{487}$ Gompared to the expansive role of the federal judiciary in modern times, the clamor over the Act is hard for us to fathom. In order to evaluate fairly the Republican response to the proposed court system, considerable effort is required, especially if we take into account some of the more ludicrous (and downright false) claims made about the new system. ${ }^{488}$ Nevertheless, there apparently was reason for Republicans to smell something foul in the air. Although the program had been discussed for years, it was tainted by the fact that it was passed under obvious time pressures. The Federalists deliberately limited the debate in Congress, and the bill was signed by President Adams on the very day his successor was being selected by the House of Representatives. ${ }^{459}$ That staunch Federalists were quickly appointed to posts in the judiciary was understandably a source of resentment. And the Republicans could not have overlooked the fact that with the Act, the federal courts' work, which previously had centered on maritime disputes, was now expected to include "an avalanche of land disputes." ${ }^{360}$ As the Act expanded diversity jurisdiction to include cases involving land titles regardless of the amount in controversy, a huge

15811 Annals of Cong. 830 (1802).

457 Only a few cases went to the new circuit courts before their abolition in 1802 .

See G. Haskins, supra note 38 , at 134 .

168 See Farrand, supra note 440 , at 682.

158 During the repeal debates Republicans made bitter remarks about the legislative process that led to the enactment of the 1801 Act. See, e.g., 11 ANNals of Cong. 597 (1802) (statement of Rep. Giles). Giles complained:

In this state of things, when all confidence amongst the members of this House was lost, in the highest paroxysm of party rage, was this law ushered into existence. And now its advocates gravely tell us to be calm, to guard against the danger of our passions. They tell us, at the the same time, that the law they have passed is sacred! inviolable! irrepealable! Does it merit this extraordinary character from the circumstance which accompanied its passage? It does not.

Id.

180 See G. Haskins, supra note 38, at 134. 
number of contested property claims from the West could be transferred to federal courts. It seems an unlikely coincidence that a sizeable number of Members in the Sixth Congress, many of whom were seasoned lawyers, speculated in land on a large scale, and were well aware of state court hostility to their ventures. ${ }^{\mathbf{4 6 1}}$

Most of the themes and accusations that had crystallized in the recent past were played out during the debates on the repeal of the 1801 Act. While Federalists spoke of "commerce increasing with great rapidity," ${ }^{\mathbf{1 0 2}}$ of preventing "moneyed capitals" from being "drawn off," 463 and of the need for "confidence as to protect property"464 by maintaining strong federal courts, Republicans attacked the very idea of a national economy. Their argument paralleled the old Antifederalist refrain from ratification days-the territory was simply too large, and customs too diverse, to permit a general government. ${ }^{465}$ Senator Abraham Baldwin set the tone:

It is readily conceived, that the Eastern Continent, as well as this Western, might have often reflected on the practicability of this vast experiment; the great discouragement which has probably prevented it, has been, that the immense and unwieldy enginery which would be necessary to carry it on, to administer its laws, and manage its money transactions, with tolerable intelligence and fidelity, and keep up the great vital circulation, is not within the compass of human faculties and

461 See Turner, supra note 160, at 28-29. Professor Turner (now Preyer) points out that not only large speculators, such as Representative Robert G. Harper and Senator James Gunn, were to profit, but also that many small investors, including the Yazoo claimants, would be benefitted. See id. at 29-30. Federalists also threw their own barbs, accusing Virginians of having excessive political influence. Representative Samuel W. Dana asked at the repeal debates, "[i]s it apprehended, that there may eventually be issued, from the Federal courts, a process which will seriously affect some of their baronial estates?" 11 ANNALS OF CoNG. 902 (1802).

462 See 11 AnNals of Cong. 34 (1802) (statement of Sen. Mason).

163 See id. at 946 (statement of Rep. Tallmadge).

164 See id.

465 Governor George Clinton of New York had urged the New York Convention to consider that the American people, in "[t]heir habits, their productions, their resources, and their political and commercial regulations, are as different as those of any nation upon earth." 2 Elliot's DeBATES, supra note 138, at 262. The proposed Constitution was dangerous and might act "cruelly," because "[i]n a small territory, maladministration is easily corrected, and designs unfavorable to liberty frustrated and punished. But in large confederacies, the alarm excited by small and gradual encroachments rarely extends to the distant members, or inspires a general spirit of resistance." Id.; see also 3 Euliot's DeBATEs, supra note 138, at 216 (James Monroe, Virginia Convention) ("Are there not a thousand circumstances showing clearly that there can be no law that can be uniform in its operation throughout the United States?"). 
endowments. ${ }^{486}$

Representative Phillip R. Thompson maintained that federal court jurisdiction was "extremely limited from the true and genuine construction of the Constitution." ${ }^{367}$ If national laws needed to be interpreted or enforced, state courts were perfectly competent for the task. "[T]here never has been an instance," declared Representative Joseph B. Varnum, "in which a State court has refused or neglected to decide with their usual promptitude, all actions which have arisen under the Federal Government ...."468 Was there some problem of "judicial imbecility or inattention, in the State courts?,"468 he demanded. For the Republicans, the danger was precisely the opposite. They interpreted the Federalist actions as demonstrating their contemplation of the "gradual demolition of the State courts, by increasing the number and extending the jurisdiction of the Federal courts . . . [which were] already filled with men who had manifested the most indecorous zeal in favor of their principles." ${ }^{370}$ Opponents of the Act would not even concede the need to eliminate circuit riding, a practice that Senator Baldwin opined had provided Justices "the opportunity of a full knowledge of local laws and usages." ${ }^{\text {"71 }}$ Finally, by returning to the old system, "more than forty thousand dollars annually" would be saved, which Representative Varnum observed "ought to have some weight with faithful Representatives of a free people, unless a public debt is in fact to be considered a public blessing."

The debate over the 1801 Act quickly became a contest to prove who was the more faithful to the ideals of the country. Just as Republicans reached back to pluck treasured wisdom from the past, so too did Federalists accuse their rivals of violating the very premises that underlay the call to the Convention in Philadelphia. In words reminiscent of those spoken by Madison at the Convention, ${ }^{\mathbf{4 7 3}}$ Representative Roger Griswold said that "it is idle to disguise the opinions which are entertained of State judicatures by persons who have a right of trial by the Constitution in your national courts. Sir, they have no confidence in

\footnotetext{
16811 AnNals of Cong. 103-04 (1802).

${ }^{467}$ Id. at 552.

168 Id. at 979.

169 Id.

170 Id. at 581 (statement of Rep. Giles).
}

${ }^{471} I d$. at 102. Republicans denied that circuit riding was causing court delays. See id. at 978-79 (statement of Rep. Varnum). The Federalists, however, thought that this view was plainly untrue and hotly contested the Republican claim. See id. at 172-73 (statement of Sen. Ogden); id. at 569-70 (statement of Rep. Stanley); id. at 617-18 (statement of Rep. Bayard); id. at 671-72 (statement of Rep. Huger).

172 .Id. at 981 .

173 See infra Part Two, notes 192 \& 199 and accompanying text. 
some of those judicatures . . .."474 Before making this remark, Griswold had produced a time-honored observation- "[t]he paper money systems of some States, and the breach of treaties in respect to the collection of debts in others taught the framers of our Constitution a conclusive lesson .... to provide for the establishment of national courts." ${ }^{475}$ Other Federalists were less polite and associated the repeal with every other Republican abuse they perceived. Representative Seth Hastings was in something of a rage:

$[W] a s$... this [not the] same party that, for twelve years, opposed all the most important measures of the Federal administration? Was it not this party that assailed, with every species of calumny and abuse, the illustrious WASHINGTON for issuing, at the commencement of the late European war, a proclamation of neutrality to this country? Was it not this same party that formed and instituted Democratic societies throughout the Union, to overawe and control the constituted authorities of our Government? Was it not the spirit of this party that excited two insurrections in a part of our country? And had not the spirit of this party been checked, it would, most undoubtedly, have involved this country in a war with a powerful foreign nation. ${ }^{478}$

Inevitably the discussion came around to the subject of common law. The issue slipped into the debate as a natural aspect of the partisan controversy. "It is sometime," Representative William B. Giles declared, "since we have seen ... judicial zeal extending the provisions of the sedition act, by discovering that it had jurisdiction of the lex non scripta, or common law!'477 Republicans incorporated the attack on federal common law into their now matured theory of states' rights. The Federalists, Representative Nicholson asserted, were claiming the existence of a law "having a uniform operation over all the extent of country now contained within the limits of the United States." Nicholson's view, this was impossible since the common law had been received differently at varying times by the several colonies, each of which "was independent of the other." W79 With the Revolution, "[t]he

47411 AnNals of Cong. 770 (1802).

475 Id.

478 Id. at 886. Hastings was referring to the Whiskey Rebellion of 1794 , see F. Aumann, supra note 151, at 177-78, and Fries' Rebellion, see Case of Fries, 9 F. Cas. 826 (C.C.D. Pa. 1799) (No. 5126); Presser, supra note 55, at 83-93.

17711 ANNALS OF CoNG. 583 (1802).

478 Id. at 806.

178 Id. at 807. 
States each became sovereign and independent, and reserved to themselves the power of self-government." 480 If a state had adopted the common law, "it ha[d] been by a solemn and positive act, expressly recognising it as a part of their code of laws." enumerated powers given by the states to the national government was there "any recognition of [the common law] ... as a law of the United States." 482

As they had during the Sedition Act debates, Federalists allowed the Republicans to define the nature of their dispute, and they attempted to debate the issues on Republican terms. So far apart were the two sides on the basic assumptions of the argument, however, that they simply passed each other in the night.

The arguments offered by the Federalists never had a chance of succeeding. Our judges "have held generally," Representative Bayard said, "that the Constitution of the United States was predicated upon an existing common law," which the colonists had left "as the most valuable inheritance to their children." "Take away the common law from your courts of law," Representative Hastings added, "and your courts cannot proceed a step." 484 This line of defense was doubly useless. In the first place, Republicans could not have cared less that Federalist judges had supported forms of common-law jurisdiction for ten years. These were the same judges, retorted Representative Giles, "who ought to have been independent," yet had "converted into political partisans, and like Executive missionaries, pronounc[ed] political harangues throughout the United States!"48s Second, Republicans did not deny the applicability of the common law where it had been specifically received by a state. Republicans could point to wide discrepancies among the various states with respect to the content of their common law, a consequence of the divergent conditions in the respective jurisdictions and the fact that the colonies were settled at differing times when English common law itself was changing. ${ }^{486}$ Representative John Randolph queried

whether that common law which they have adopted for the United States, be the common law as it stood modified by statute in the reign of Elizabeth and James the First, prior

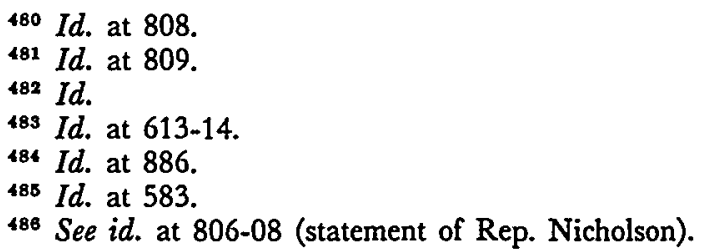


to the existence of the act of habeas corpus, divested of all the salutory provisions afterwards introduced at the Revolution; or, whether it be the common law of the time of George the Second? Whether we are to be governed by the common law of Sir Walter Raleigh and Captain Smith, or that which was imported by Governor Oglethorpe; or on which of the intermediate periods they have chosen as fixing the common law of these States? ${ }^{487}$

Federalists responded by interjecting a tired rebuttal: without the common law certain terms in the Constitution were meaningless, and that some of the provisions-such as the jury trial provision in the seventh amendment for "suits at common law"-expressly recognized the common law. ${ }^{488}$ The Republican counter to this position demonstrates how far apart the two sides were. "That the common law is to settle the meaning of common law phrases, few will feel disposed to deny,"489 was the easy concession made by Republicans. As John Randolph explained, that was simply not their point:

But because the common law is to be resorted to for an explanation of these and similar terms, does it follow that that indefinite and undefinable body of law is the irrepealable law of the land? The sense of a most important phrase, " $d i$ rect tax," as used in the Constitution, has been, it is believed, settled by the acceptation of Adam Smith; an acceptation, too, peculiar to himself. Does the Wealth of Nations, therefore, form a part of the Constitution of the United States? ${ }^{490}$

Like Randolph, other Republicans voiced the odd contention from prior exchanges, that if the common law was adopted by the Constitution, it became a part of the Constitution, and could not be altered by Congress. ${ }^{491}$ This proposition illustrates the extraordinary variance in the essential postures of the parties. Federalists were contending, though not very artfully, that all courts had a recognized function, one defined by the customs of the land from which most Americans owed their origin. This was not an alien law-the use of common-law terms in the Constitution established that much. In providing for courts under article III, the people could be presumed to have given the federal

487 Id. at 652.

${ }^{488}$ See id. at 734 (statement of Rep. Goddard).

48 Id. at 652 (statement of Rep. Randolph).

480 Id. at 652.

491 See id. at 809 (statement of Rep. Nicholson). 
courts the powers ordinarily exercised by judicial bodies, which included defining crimes against the government.

Republicans opposed this stance by insisting that governments derive every bit of their authority from the consent of the people. Jefferson had written shortly before these debates that each act of government, whether legislative, judicial, or executive, is an expression of a single sovereign, and "[i]t is the will of the nation which makes the law obligatory . . . ."482 Where, then, had the people expressed their intention to adopt the common law of England? And "why English law," asked Representative Nicholson, any "more than the laws of France, Spain, Sweden or Holland?"493 If the people had adopted English common law through ratification of the Constitution, then it must follow that the common law is a species of constitutional law.

Making sense of these arguments is an exceptionally difficult task, especially if one is attempting to construct a coherent position for either side. As will be developed in Part Two of this essay, the views of both parties suffered fundamental weaknesses. For present purposes, what is important to consider is whether either camp took seriously the contentions that were being bantered about. Contrary to what Republicans had suggested, Federalists never claimed that the common law was equivalent to the Constitution and hence unalterable by legislative act. On the other hand, for Federalists to allege that the Republican position rendered federal courts without any capacity to act, for want of a substantive law base, was just as absurd. A more reasonable view would have the federal judiciary authorized to develop common law by express congressional act, assuming that the statute was within an area of national legislative competence.

This last point rested at the heart of the matter, since Republicans and Federalists disagreed over what the national government was permitted to do under the initial constitutional delegation. Some Republicans, such as Senator John Breckenridge, conceded a limited power in the federal government to punish crimes in the absence of statutory authorization. ${ }^{494}$ These were the crimes specifically mentioned in the Constitution, which encompassed "but three or four species . . . to wit: treason, piracies, and felonies on the high seas, offences against the laws of nations, and counterfeiters of securities or coin of the United States." ${ }^{495}$ Whether the Constitution conferred upon federal courts the

192 Letter from Thomas Jefferson to Edmund Randolph (Aug. 18, 1799), supra note 432 , at 74 .

19311 Annals of Cong. 809 (1802).

194 See id. at 97.

${ }^{498}$ Id. Breckenridge continued: 
power to adopt the common law generally was an entirely different question-even if Congress had provided for the jurisdiction. Led by Jefferson, Republicans insisted this was "infinitely beyond [the] power" of Congress, and if "yielded to, the state courts may be shut up."488

In addition to the federalism issue, Republicans began to raise with increasing clarity separation of powers concerns. Since no express authorization could be identified, the Republicans warned that "this adopting the common law is only another name for legislation."497 Representative Macon saw this judicial "power of legislating" as "extremely dangerous" since judges were not elected by the people. ${ }^{498}$ "It is giving to the judges a power infinitely more transcendant than that vested in any other branch of the Government," added Nicholson-a type of "extensive discretionary power" exhibiting a "monarchical tendency." 489

A comprehensive reading of these debates reveals an interconnection of reason and unbridled invective. Republicans charged that Federalists were "wild and arbitrary," as voicing "noisy declamations." came out with reminders of "the horrid scenes which have lately passed in review before us in France." seems quite inflated, there were serious ramifications involved in the Republican proposals. They were not merely taking the country back to the judicial system set up in 1789. Part of the package was the removal from office of federal judges who were supposed to have lifetime tenure under article III. With some justification, the Federalists saw their opponents as thorough hypocrites, espousing in one breath the sacredness of the Constitution and then disregarding the precise lan-

These constitute their powers on the subject of criminal jurisprudence, and are the sum total of our powers, written or unwritten; unless, indeed, the gentlemen draw some of their authority for their extensive notions of legislation, from the lex non scripta of Alfred's country, which I am told some gentlemen consider as attaching itself to our Constitution.

Id.

408 Letter from Thomas Jefferson to Edmund Randolph (Aug. 18, 1799), supra note 432 , at 73 .

19711 Annals of Cong. 713 (1802) (statement of Rep. Macon).

$498 \mathrm{Id}$.

489 Id. at $806,805$.

${ }^{800}$ Id. at 808 (statement of Rep. Nicholson) ("I would have wished that on this subject, as well as many others, the gentleman had offered us something like an argument, instead of mere wild and arbitrary assertion.").

${ }^{801}$ Id. at 583 (statement of Rep. Giles).

${ }^{802}$ Id. at 734 (statement of Rep. Goddard). Representative Goddard recalled: "They are too recent and too horrible to soon be forgotten. Too horrible indeed to be mentioned." Id. 
guage of the document in another. They suspected a general conspiracy aimed at the federal judiciary, ${ }^{503}$ and they were not far off the mark. Representative Giles had written Jefferson the past year that "a pretty general purgation of office has been one of the benefits expected by the new order of things." "so4 A few months later, as Jefferson recorded, Giles was more specific: "[N]o remedy is competent to redress the evil but an absolute repeal of the whole judiciary system [of 1801] terminating the present offices and creating an entire new system, defining the common law doctrine, and restraining to the proper constitutional extent the jurisdiction of the courts."

The repeal of the 1801 Act was only the first shot fired by Republicans in a struggle against the federal judiciary that would rage for well over a decade. While Justice Chase survived the impeachment charges brought against him in 1804, the Republican attempt left an imprint on the Court's work. ${ }^{508}$ As is evidenced by partisan impeachment attempts at both the state and federal levels, hostility toward

sos See L. KeRBER, supra note 146, at 172 ("Those phases of the debate which concentrated on the 'reception' of the common law went far toward solidifying the Federalist conviction that their opponents' purpose in espousing repeal was both anti-intellectual . . . and conspiratorial .....").

sot Letter from William B. Giles to Thomas Jefferson (Mar. 1801), quoted in W. Carpenter, Judicial Tenure in the United States 58 (1918). Jefferson replied to Giles "in confidence," saying that

all appointments to civil offices during pleasure, made after the event of the election was certainly known to $\mathrm{Mr}$. A, are considered as nullities. . . Good men, to whom there is not objection but a difference of political principle, practised on only as far as the right of a private citizen will justify, are not proper subjects of removal, except in the case of attorneys \& marshals. The court being so decidedly federal \& irremovable, it is believed that republican attorneys \& marshals, being the doors of entrance into the courts, are indispensably necessary as a shield to the republican part of our fellow citizens, which, I believe, is the main body of the people.

Letter from Thomas Jefferson to William B. Giles (Mar. 23, 1801), reprinted in 9 The Works of Thomas Jefferson 222-23 (P. Ford ed. 1905). On Jefferson's policies concerning appointments, see D. Malone, Jefrersson The President: First TERM 1801-1805, at 69-89 (1970); Prince, The Passing of the Aristocracy: Jefferson's Removal of the Federalists, 1801-1805, 57 J. AM. Hist. 563 (1970):

${ }^{805}$ See W. Garpenter, supra note 504, at 59 (quoting Jefferson Manuscripts dated June 1, 1801).

soo See Presser, supra note 55, at 110 (arguing that the impeachment of Chase caused Marshall to avoid, to the extent possible, "plung[ing] the Court into the political thicket" (footnote omitted)). There was more than a little irony in article 6 of the impeachment charges against Chase, which accused him of ignoring Virginia criminal procedure in a notorious Sedition Act prosecution. Chase's adversaries alleged that $\S 34$ of the Judiciary Act required that state law should have been applied, even though it was a federal criminal case. See 14 AnNals of Cong. 730 (1804) (article 6 of the impeachment charges). 
courts of all types was a phenomenon of this era. ${ }^{507}$ Herbert Johnson has written that the Justices were left "with few illusions concerning the power of public opinion and political majorities to alter the course of constitutional development and the role of the Court itself." assessing the development of the common-law powers of federal courts at this critical juncture, it is important to recognize that Republicans were challenging the basic concept of an independent judiciary. From the Federalist perspective, this was precisely what was at stake. They were convinced that "[ $t$ ]he removal of the Judges, \& the destruction of the independence of the judicial department, has been an object on which Mr. Jefferson has been long resolved." ${ }^{509}$

Federalists insisted that the judiciary must be free to act without legislative domination. When the Republicans repealed the 1801 Act, Federalists were certain that the Congress and the Executive had combined in "the very essence of tyranny." 510 Writing in the New-York Evening Post in early 1802, one Lucius Crassus (probably Hamilton) predicted the fall of the country:

'Till the experiment had proved the fact, it was hardly to have been imagined, that a majority of either house of Congress, whether from design or error, would have lent its sanction to a glaring violation of our national compact, in that article, which of all others is the most essential to the efficiency and stability of the Government; to the security of property; to the safety and liberty of person. This portentous and frightful phenomenon has, nevertheless, appeared. It frowns with malignant and deadly aspect upon our constitution. Probably before these remarks shall be read, that Constitution will be no more! It will be numbered among the numerous victims of Democratic phrenzy; and will have given another and an awful lesson to mankind-the prelude perhaps of calamities to this country, at the contemplation of which imagination shudders!

... [I]f they are not arrested in their mad career, [Republicans] will, ere long, precipitate our nation into all

${ }^{507}$ See W. CarpenTer, supra note 504, at 111-13 (describing the impeachments in 1803 of a federal district judge in New Hampshire and of state judges in Pennsylvania).

${ }^{\circ 08}$ H. JOHNSON, supra note 54, at 373.

809 W. Plumer's Memorandum of Proceedings in the United States Senate, 1803-1807, at 101 (E. Brown ed. 1923), quoted in G. Haskins, supra note 38, at 205.

510 11 Annals of Cong. 576 (1802) (statement of Rep. Stanly). 
the horrors of anarchy. ${ }^{511}$

At the repeal debates-while Marbury v. Madison was pending-Federalists in Congress publicly came out in favor of the judicial power to declare a legislative act void as unconstitutional. ${ }^{512}$ The Federalist position on judicial review revealed in these sessions bears a remarkable resemblance to the eventual opinion for the Court in Marbury. Deprived of a majority in Congress, they had only one card to play-that the repealing act would be found unconstitutional by the federal courts. ${ }^{513}$ Republicans responded quickly to this suggestion, and the result was a vehement exchange, ${ }^{514}$ which ranged in tone from rare eloquence in a legislative chamber to outright threats of impeachment should the Justices dare such a move. ${ }^{515}$

Senator Aaron Ogden argued for the Federalists: "Suppose the Legislature should pass bills of attainder, or an unconstitutional tax, where can an oppressed citizen find protection but in a court of justice firmly denying to carry into execution an unconstitutional law ?'"51B $\mathrm{Re}-$ publican legislators had a simple answer: "[A]re we not as deeply interested in the true exposition of the Constitution as the judges can be?"517 Although some Republicans were willing to allow that judges might not be bound to execute laws that they thought were unconstitutional, declaring an act "null and void" was quite another matter, a

${ }^{611}$ The Examination No. XII, New-York Evening Post, Feb. 23, 1802, reprinted in 25 The Papers of Alexander Hamilton 529-30 (H. Syrett ed. 1977) For support that Hamilton was the author, see $i d$. at 444-53.

s12 See, e.g., 11 AnNals of Cong. 164 (statement of Sen. Ross). As Ross explained:

Here the written Constitution, established by the people, restrains the legislature to the exercise of delegated power, and finds immutably certain bounds which it may not pass. If it should rashly exceed the delegated power, our Judiciary, sworn to support the Constitution, must declare that the great irrepealable statute made by the people shall restrain and control the unauthorized acts of agents who have exceeded the limits of a special authority.

Id; see also R. Ellis, supra note 71, at 58 (explaining that in the eyes of the Federalists only an independent judiciary could protect the country from a tyrannical legislature). On earlier statements by federal judges endorsing judicial review of legislation, see supra notes 394-95 and accompanying text.

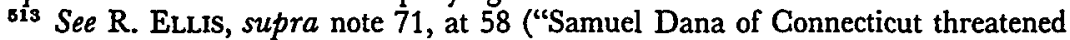
that if the Republicans should pass the repeal act, the Supreme Court would annul it." (footnote omitted)).

o14 See 1 C. Harnes, supra note 361, at 227-35 (describing Federalist and Republican arguments in the debate on the repeal of the $1801 \mathrm{Act}$ ).

${ }_{515}$ See R. Ellis, supra note 71, at 58 ("These arguments usually concluded with the warning that if the repeal act were declared unconstitutional, impeachment of the justices of the Supreme Court was sure to follow."(footnote omitted)).

s16 11 AnNals of Cong. 175 (1802).

B17 Id. at 661 (statement of Rep. Randolph). 
"power [that] rests alone with the Legislature."

Federalists responded that the Republican position was "monstrous and unheard of."s19 "[W] hat possible mode is there to avoid the conclusion," demanded Senator Gouverneur Morris, "that the moment the Legislature of the Union declare themselves supreme, they become so?" 200 This Constitution, the Federalists chided, "is the act of the political sovereign, the People of the United States." majority in Congress was prepared to commit the unconstitutional act of displacing federal judges by repealing their offices. The Federalists warned that "the irresistible consequence is, that whatever law is passed the judges must carry into execution, or they will be turned out of office."

Republicans denied that the repeal was unconstitutional. It merely curtailed jurisdiction, which was unconstitutionally expanded in the first place, and therefore obviated the need for the judges' services. Moreover, if the representatives were wrong about this, they could be sent packing at the next election. ${ }^{\mathbf{5 2 3}}$ The bottom line of the Republican stance was that sovereignty rested with the people, and could only be expressed through public officials accountable to the electorate. ${ }^{\mathbf{5 2 4}}$ Senator Stevens T. Mason predicted that if the judges were permitted to have the final authority, "they will presently become so strong as to crush and absorb all the others into their solid mass." Representative Thomas T. Davis said, at the idea of permitting federal courts to "check this House and the Senate." we put men out of power, who we find determined to act in this manner, the better; by doing so we preserve the power of the Legislature, and save our nation from the ravages of an uncontrolled Judiciary."

Senator Ogden thought that this fear of the courts was totally unfounded: "[W]here can such power be more safely lodged than in that branch of the Government, which, holding neither the sword nor the purse of the nation, cannot have either the ambition or the means of

${ }^{B 18} I d$. at 558 (statement of Rep. Davis).

519 Id. at 529 (statement of Rep. Henderson).

B20 Id. at 181 .

s21 Id. at 127 (statement of Sen. Chipman).

s22 Id. at 529 (statement of Rep. Henderson).

s2s See id. at 552 (statement of Rep. Thompson) (Members of Congress "are biennially responsible to their constituents for the sacred observance of the charter of their rights.").

524 "The decision of a Constitutional question must rest somewhere," John Randolph said. "Shall it be confided to men immediately responsible to the people, or to those who are irresponsible?" Id. at 661.

${ }^{528} \mathrm{Id}$. at 63.

${ }^{528} I d$. at 558.

${ }^{527}$ Id. 
subverting, to their own benefit, the provisions of our Constitution?"3528 This sentiment paralleled that expressed in the 78 th Federalist, $^{\mathbf{6 2 \theta}}$ and was no more likely to persuade a Republican than were the original words of Hamilton. Jefferson's followers were perfectly aware of what the judiciary was capable of accomplishing. Republicans felt that it was naive to think that judges were incapable of combining their powers with those in other branches of government who shared the same partisan outlook.

Probably the most important aspects of the issues of this period were the inability of the political actors to evaluate a single proposal apart from the larger picture, and the inseparability of the whole from concerns for abuse of power by known individuals. Consider, for example, how Representative Giles could link a series of matters:

[A]ll men love power, and in general, those love it best who know best how to use it. Let us apply this remark to the judges of the United States.

Very shortly after the establishment of the courts, the judges decided that they had jurisdiction over the States in their sovereign capacity. Did this, in the judges, seem unambitious? The States thought it did not. It happened that during the Revolutionary War, the State of Massachusetts had issued certain obligatory bills, which were made transferable, and which were outstanding without any provision for their payment; suits were instituted on these bills. The court determined to bring the great State of Massachusetts, and not Virginia, on its knees, not at the feet of justice, but policy .... The judges have determined that they are judges in the last resort upon the constitutionality of your laws. ... The judges have determined that their jurisdic-

${ }^{528} \mathrm{Id}$. at $175-76$. wrote:

${ }^{329}$ See The Federalist No. 78 (A. Hamilton) (J. Cooke ed. 1961). Hamilton

Whoever attentively considers the different departments of power must perceive, that in a government in which they are separated from each other, the judiciary, from the nature of its functions, will always be the least dangerous to the political rights of the constitution; because it will be least in a capacity to annoy or injure them. The executive not only dispenses the honors, but holds the sword of the community. The legislature not only commands the purse, but prescribes the rules by which the duties and rights of every citizen are to be regulated. The judiciary on the contrary has no influence over either the sword or the purse, no direction either of the strength or of the wealth of the society, and can take no active resolution whatever.

Id. at 522-23. 
tion extends to the lex non scripta, or rather to the lex non descripta, or common law. Does this, in the judges, seem unambitious? This law pervades the whole municipal regulations of the country. It is unlimited in its object, and indefinite in its character. Legalize this unassuming claim of jurisdiction by the judges, and they have before them every object of legislation. They have sent a mandatory process, or process leading to a mandamus, into the Executive cabinet, to examine its concerns. Does this, in the judges, seem unambitious? ${ }^{530}$

This alleged tie between judicial review and the common-law authority of federal courts sheds light on why Republicans insisted that their rivals were claiming the common law to be a species of constitutional law. They were forecasting what they thought a Federalist Supreme Court might try to accomplish. Representative Joseph H. Nicholson said:

Give them the powers and the independence now contended for, and they will require nothing more; for your Government becomes a despotism, and they become your rulers. They are to decide upon the lives, the liberties, and the property of your citizens; they have an absolute veto upon your laws by declaring them null and void at pleasure; they are to introduce at will the laws of a foreign country, differing essentially with us upon the great principles of government; and after being clothed with this arbitrary power, they are beyond the control of the nation, as they are not to be affected by any laws which the people by their representatives can pass. ${ }^{631}$

sso 11 Annals of Cong. 595-96 (1802). Charles Warren wrote:

Contemporary writings make it very clear that the Republicans attacked the decision [in Marbury], not so much because it sustained the power of the Court to determine the validity of Congressional legislation, as because it enounced the doctrine that the Court might issue mandamus to a Cabinet official who was acting by direction of the President.

1 C. WARREN, supra note 38 , at 232. Considering the debates on the repeal of the 1801 Act, Warren's observation may overstate the case. The issues pending in Marbury had been debated thoroughly, and although there was certainly Republican outrage at the issuance of process to the Executive (as the quote in text shows), the objection to judicial review itself was significant in the exchange. What must not be overlooked in this epoch was the intertwining of issues-one cannot pull a single matter out as predominant. Republicans saw the issuance of process and the claim of judicial review as part of a larger attempt by the Court-the one national Federalist institution that remained-to assert supremacy.

831 11 ANNALS OF CoNG. 823-24 (1802). 
Republicans were willing to admit that the branches must "be kept separate and distinct." ${ }^{\text {"582 }}$ It was the Federalists who endangered the doctrine, by giving "to the Judiciary the power to annul your laws, and contend[ing] that the common law is attached to the Constitution.".sss

\section{SumMary OF PÁRT ONe}

This half of the essay has presented the political history of the question of common-law powers for federal courts in the early years of the American republic. Rather than accept uncritically the Hudson Court's rendition of this history, we have examined the place of the issue in the political controversies of the new nation. The problem of defining the common-law authority of federal courts, though significant as a technical legal issue, went far beyond the province of the bench and bar to absorb the attention of the leading public figures as the country moved into a period of domestic and international turmoil in the late 1790's. That the question of federal common law became an object of strident exchanges is an indication of the relationship it bore to other vital concerns of the day.

Republicans saw this matter as a swatch from a much larger cloth. For them, the assertion of common-law jurisdiction by federal courts implicated the very nature of the national Union: the extent to which powers had been transferred from the states to the federal government. Federal common law was to Republicans a symbol of a consolidated national government, the achievement of which seemed the evident goal of scheming Federalists. As such it was perceived as threatening the character of a republican society. Not only was the common law being imposed on the people without their consent, but it was an alien system, one appropriate to monarchy. Federal judges, unelected, unaccountable and yet thoroughly partisan, were seen as using common-law jurisdiction to transfer the political authority of the states to Federalist conspirators.

It is unlikely that any Federalist could be fairly accused of the entire range of Republican charges. There were in fact differences amongst the Federalists themselves over the common law as it related to the federal judiciary. Nevertheless, something of a consistent position seemed to be emerging from the Federalist camp by the end of the 1790 's. The coherency of their stance, however, was obscured by the blending of two different arguments. Federalists first argued that the

882 Id. at 553 (statement of Rep. Thompson).

833 Id. at 554. 
law of the United States, including the Constitution, must inevitably be formed against the backdrop of the common law of England. They made the reasonable claim that American law, which was largely a system of traditional rules, could not be comprehended without taking into account the vast body of case law from the English past. Further, the common law was the source of Americans' most important liberties-the foundation of due process and the protection of estate.

But Federalists went beyond these assertions to a second, and much more ambitious, undertaking. Beginning shortly after the formation of the national government, they took the view that federal courts had a type of common-law jurisdiction. This was initially put forth as a justification for nonstatutory criminal prosecutions, particularly in cases implicating America's neutrality stance. In a society familiar with such proceedings, the idea of punishing someone without a legislative declaration of the offense was not especially novel or troublesome. Even Jefferson was confident in resorting to a nonstatutory prosecution for Henfield's Case. What prompted the controversy over federal common law was the use of these prosecutions for political purposes during the crisis period at the close of the decade.

The Federalist position that federal courts had a common-law jurisdiction was itself inherently ambiguous. Republicans accurately pointed out that the common-law courts of England had a national jurisdiction, and that the common law itself was a system of jurisprudence that encompassed most of the important legal affairs of that country. Federalists denied any intention to equate the common-law authority of the English courts with that of the federal courts. Missing from their assurances, however, was any precise delineation of the limits of federal jurisdiction. Further hampering Federalist efforts to assuage Republican fears was the persistent rhetoric from leading Federalists to the effect that the common law was the law of the United States, and had somehow been adopted by the Constitution.

In the end the Federalists never articulated a theory to explain the sort of jurisdiction they associated with the federal court system. Their failure to do so was but one part of Federalists' general inability to depict the boundaries of the national government. Republicans correctly perceived that their opponents wanted authority at the Federal level equal to the task of supporting ambitious national programs. Judicial power was simply an aspect of these larger aspirations, and no more clearly deliniated than the others.

Republicans, for their part, were more successful in arguing that the federal courts, like the rest of the national government, should be confined to a few narrow areas of competence. If the Republican pos- 
ture made sense as a political program, it did so at the expense of offering a sound conceptual foundation for federal jurisdiction. It simply could not be denied that the common law would be the basis for much of the judicial activity in this country. Nor was it possible to ignore the fact that article III of the Constitution plainly contemplated that federal courts would have a national jurisdiction, often exclusive of the states.

All of the parties in this dispute purported to be adhering to the true meaning of the Constitution. On the points that were decisive to the debate, however, the Constitution was strikingly vague. It quickly became apparent that the adoption of the Constitution was merely the starting point for a long and eventually violent political battle. While the Constitution's ratification provided something of an institutional framework in which the political contest could be held, and resulted in the initial conferral of important powers on certain individuals, it left unresolved the crucial issue of the scope of national powers. The partisan confrontation over the common-law authority of federal courts was only a moment in this wider struggle for national definition. 


\section{APPENDIX}

\section{Grand Jury Charge of Chief Justice Oliver Ellsworth, Circuit Court for the District of South Carolina (May 15, 1799)1}

\section{Gentlemen of the Grand Jury,}

THE matters of delinquency to which your enquiry and presentments will extend, are, all offences against the United States, committed within the district of South-Carolina; or upon the high seas, by persons found here. Those offences are chiefly defined in the statutes, with which you are presumed to be acquainted: the residue are, either acts contravening the law of nations, cases which you will rarely meet with; or they are acts manifestly subversive of the national government, or of some of its powers specified in the constitution. I say manifestly subversive, to exclude acts of doubtful tendency, and confine criminality to clearness and certainty.

An offence consists in transgressing the sovereign will, whether that will be expressed, or obviously implied. Conduct therefore, clearly destructive of a government, or its powers, which the people have ordained to exist, must be criminal. It is not necessary to particularlize the facts falling within this description, because they are readily perceived, and are ascertained by known and established rules; I mean the maxims and principles of the common law of our land. This law, as brought from the country of our ancestors, with here and there an accommodating exception, in nature of local customs, was the law of every part of the union at the formation of the national compact; and did, of course, attach upon or apply to it, for the purposes of exposition and enforcement. It is true, that the parties acting in their sovereign capacity, might have discontinued that law, with respect to their new relations, and the duties thence arising, and have left them to arbitrary decisions: but that they intended a discontinuance so contrary to usage in similar cases, and so pregnant with mischief, is certainly not to be presumed; and it is a supposition irreconcilable with those frequent references in the constitution to the common law, as a living code.

By the rules then, of a known law, matured by the reason of ages, and which Americans have ever been tenacious of as a birth right, you will decide what acts are misdemeanors, on the ground of their opposing the existence of the national government, or the efficient exercise of its legitimate powers.

1 Reprinted in Claypoole's Daily Advertiser (Philadelphia), May 31, 1799. For other newspapers reprinting this Charge, see supra note 404. 
Such, gentlemen, very briefly, is the written and the unwritten law, which you will regard; and, by an impartial and faithful application, cause to be respected.

Although an indictment is but an accusation, leaving to the party the right of a traverse; yet it affects too nearly his fame and his liberty, to be founded upon suspicion; and much less on prepossession. If juries, instead of being a shield from oppression, would not become the instruments of it, let them look, not to the opinions of men, but their actions; and weigh them, not in the scales of passion or of party, but in a legal balance-a balance which is undeceptive-which vibrates not with popular opinion; and which flatters not the pride of birth, or encroachments of power.

It is not however, the whole design of your institution, to save the innocent: a less pleasing, but not a less essential part, is, to bring the guilty to punishment.

Punishment, it is said of the Supreme Being, "is his strange work;" and it certainly is so of every human being, who retains his social impressions. But till avarice and ambition, shall cease to progress with society, or become capable of a nobler restraint than fear, penal justice will be salutary. And we shall continue to admire that organization of inquests for its certainty, which combines with means of information and motives of arraignment, independency of condition and weight of character.

Unmoved by the misconception of severity of laws, you will also, I trust, be unembarrassed with the policy of them. Whether they are wise or not, are to be sure, questions of responsibility with those who enact them: though frequently dependent so much on a knowledge of the past and of the future, as well as of the present; so much on opinion, in reconciling domestic interests; and so little on calculation, in managing those which are foreign, as not to be easily decided. Admitting, however, that the purity and the patriotism of our legislators, still leave them liable to error; it does not impair, at all, the obligation of the citizens to obey, or of the magistrate to execute. 'Till they overleap the constitution, which guarded as they are by revisionary checks, and dependent as they are on public confidence, is not to be expected; and, certainly not to believed to have happended, while a saving construction still remains: till then, the laws they proscribe are sacred and should be resistless. Neither the judicial, or executive department, can for a moment, refuse them effect. It violates, together with their oaths, that distribution of power, without which civil liberty amounts to little, and republican hopes to nothing. It is, under our constitution, a mutiny of authorities; and, in our condition, a mutiny is a tempest! 
To this sketch of your duty, gentlemen, it cannot be necessary to add persuasion. You feel that you have a country, and believe there is a God. 